\title{
Panduan untuk Pengembangan, Pengujian dan Pemilihan Kriteria dan Indikator untuk Pengelolaan Hutan Lestari
}

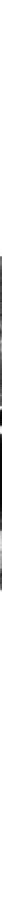

Perangkat Kriteria dan Indikator 


\section{PANDUAN UNTUK PENGEMBANGAN, PENGUJIAN DAN PEMILIHAN KRITERIA DAN INDIKATOR UNTUK PENGELOLAAN HUTAN LESTARI}

RUJUKAN BAGI PENGEMBANG K\&I

PERANGKAT KRITERIA DAN INDIKATOR 
(C) 1999 oleh Center for International Forestry Research

Dicetak oleh SMK Grafika Mardi Yuana, Bogor

Fotografi

Panther onca oleh Tony Rath (WWF)

Pembalakan oleh Anonymous

Kenyah wanita, Tanah Merah, Indonesia oleh Alain Compost

Bulbophyllum sp. (Anggrek Liar) oleh Pliono Sist

Para penulis ingin menyatakan penghargaan kepada Herlina Hartanto, Herry Purnomo, Daju Pradnja Resosudarmo, Rahayu Koesnadi, Agus Salim, Abdurrahman Syebubakar, Meilinda Wan dan Yurdi Yasmi yang melakukan pengecekan kualitas terjemahan seri perangkat ini, dan juga kepada Meiske D. Tapilatu dan Dwiati Novita Rini yang melakukan pengecekan selama proses persiapan pencetakan.

ISBN: 979-8764-35-8

Diterbitkan oleh

Center for International Forestry Research (CIFOR)

Alamat: PO Box 6596 JKPWB, Jakarta 10065, Indonesia

Telepon: +62-251-622622 Fax: +62-251-622 100

E-mail: cifor@cgiar.org

WWW: http://www.cgiar.org/cifor

Dengan dukungan dana dari

The European Commission

Anggaran B7-6021 yang berkaitan dengan 'Hutan Tropis'

Brusel, Belgia

Deutsche Gesellschaft für Technische Zusammenarbeit (GTZ) GmbH

Eschborn, Jerman

United States Agency for International Development (USAID)

Washington D.C., Amerika Serikat

Pencetakan edisi bahasa Indonesia ini sebagian besar didanai oleh kantor Ford Foundation di Indonesia. 


\section{Seri Perangkat K\&I}

\begin{tabular}{|c|c|}
\hline Perangkat K\&I No. 1 & $\begin{array}{l}\text { Panduan untuk Pengembangan, Pengujian dan Pemilihan } \\
\text { Kriteria dan Indikator untuk Pengelolaan Hutan Lestari } \\
\text { Prabhu, R., Colfer, C.J.P. dan Dudley, R.G. }\end{array}$ \\
\hline Perangkat K\&I No. 2 & $\begin{array}{l}\text { Acuan Generik Kriteria dan Indikator CIFOR } \\
\text { Tim KEI CIFOR }\end{array}$ \\
\hline Perangkat K\&I No. 3 & $\begin{array}{l}\text { Perangkat Modifikasi dan Adaptasi Kriteria dan Indikator } \\
\text { (CD-ROM) } \\
\text { Prabhu, R., Haggith, M., Purnomo, H., Rizal, A., Sukadri, } \\
\text { D., Taylor, J. dan Yasmi, Y. }\end{array}$ \\
\hline Perangkat K\&I No. 4 & $\begin{array}{l}\text { Panduan Induk Kriteria dan Indikator CIFOR } \\
\text { McDougall, C., Isbadi, I.R., Santoso, L., Corless, M. dan } \\
\text { Purnomo, H. (ed.) }\end{array}$ \\
\hline Perangkat K\&I No. 5 & $\begin{array}{l}\text { Panduan Penilaian Dasar Kesejahteraan Manusia } \\
\text { Colfer, C.J.P., Brocklesby, M.A., Diaw, C., Etuge, P., Günter, } \\
\text { M., Harwell, E., McDougall, C., Porro, N.M., Porro, R., } \\
\text { Prabhu, R., Salim, A., Sardjono, M.A., Tchikangwa, B., Tiani, } \\
\text { A.M., Wadley, R.L., Woelfel, J. dan Wollenberg, E. }\end{array}$ \\
\hline Perangkat K\&I No. 6 & $\begin{array}{l}\text { Panduan Pendamping Penilaian Dasar Kesejahteraan } \\
\text { Manusia } \\
\text { Colfer, C.J.P., Brocklesby, M.A., Diaw, C., Etuge, P., Günter, } \\
\text { M., Harwell, E., McDougall, C., Porro, N.M., Porro, R., } \\
\text { Prabhu, R., Salim, A., Sardjono, M.A., Tchikangwa, B., Tiani, } \\
\text { A.M., Wadley, R.L., Woelfel, J. dan Wollenberg, E. }\end{array}$ \\
\hline Perangkat K\&I No. 7 & $\begin{array}{l}\text { Panduan Cara Pemberian Skor dan Analisis untuk Menilai } \\
\text { Kesejahteraan Manusia } \\
\text { Salim, A. dan Colfer, C.J.P., dengan McDougall, C. }\end{array}$ \\
\hline Perangkat K\&I No. 8 & $\begin{array}{l}\text { Siapa yang Perlu Diperhitungkan? Menilai Kesejahteraan } \\
\text { Manusia dalam Pengelolaan Hutan Lestari } \\
\text { Colfer, C.J.P., Prabhu, R., Günter, M., McDougall, C., Porro, } \\
\text { N.M. dan Porro, R. }\end{array}$ \\
\hline Perangkat K\&I No. 9 & $\begin{array}{l}\text { Panduan untuk Menerapkan Analisis Multikriteria dalam } \\
\text { Menilai Kriteria dan Indikator } \\
\text { Mendoza, G.A., dan Macoun, P. dengan Prabhu, R., Sukadri, } \\
\text { D., Purnomo, dan Hartanto, H. }\end{array}$ \\
\hline Perangkat K\&I No. 10 & $\begin{array}{l}\text { Metodologi untuk Menilai Indikator Ekologis dalam } \\
\text { Pengelolaan Hutan Lestari (Dalam persiapan) }\end{array}$ \\
\hline
\end{tabular}




\section{DAFTAR ISI}

1. PENDAHULUAN ..................................................................... 1

1.1. Tujuan Panduan ini .................................................................... 1

1.2. Sasaran Pengujian K\&I ............................................................ 3

1.3. Ringkasan Proses Pengembangan K\&I ...................................... 3

2. PERSIAPAN PENGUJIAN K\&I ............................................... 7

2.1. Tinjauan Konsep Kerangka Kerja K\&I ................................... 7

2.2. Langkah Awal dalam Penyusunan K\&I .................................... 8

2.3. Pemilihan Set Awal K\&I ............................................................. 9

2.4. Pemilihan Lokasi ...................................................................... 11

2.5. Tim Pakar dan Koordinator Pengujian ..................................... 12

3. PROSEDUR PENGUJIAN K\&I ............................................... 19

3.1. Ikhtisar Berbagai Metode ........................................................... 19

3.2. Evaluasi Pra-lapang K\&I: Filter No. 1 ..................................... 23

3.3. Pengujian Lapang K\&I: Filter No. 2 ……............................... 31

3.4. Lokakarya: Filter No. 3 …….................................................... 51

4. ANALISIS LANJUTAN …....................................................... 59

4.1. Setelah Lokakarya ............................................................ 59

4.2. Beberapa Tambahan sebagai Pertimbangan ............................ 62

5. KONSEP DASAR PENGEMBANGAN K\&I ......................... 67

5.1. Menafsirkan Pengelolaan Hutan Lestari .................................... 67

5.2. Memahami Prinsip, Kriteria, Indikator dan Pengukur

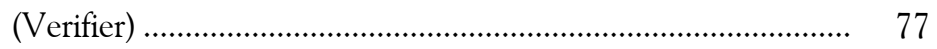

5.3. Penentuan Kesesuaian K\&I .................................................. 82 
6. TIGA STUDI KASUS

6.1. Prakarsa African Timber Organization (ATO) tentang Prinsip, Kriteria dan Indikator untuk Pengelolaan Hutan Lestari di Afrika: Pengujian di Gabon

6.2. Pengujian di Amerika Utara terhadap Kriteria dan Indikator Hutan Lestari

6.3. Pengujian dan Pengembangan Kriteria dan Indikator untuk Hutan yang Dikelola Masyarakat

\section{LAMPIRAN}

8.1. Contoh Formulir 1

8.2. Contoh Formulir 2

8.3. Perangkat Penilaian K\&I Sosial

8.4. Contoh Cara Menyusun Tabel dan Menyajikan Daftar Akhir K\&I

8.5. Glosari

9. BERBAGAI KEMUNGKINAN SET DASAR K\&I

9.1. Acuan Generik Kriteria dan Indikator CIFOR

9.2. Contoh Lain Set K\&I untuk Tingkat Unit Pengelolaan Hutan (di luar CIFOR)

9.3. Contoh Kerangka Kerja K\&I untuk UPH

9.4. Set K\&I untuk Kerangka Kerja Regional

\section{Daftar Gambar}

Gambar 1. Diagram alir evaluasi dan proses pengembangan K\&I......

Gambar 2. Diagram alir berbagai metode yang digunakan untuk mengevaluasi $K \& I$ selama pengujian berlangsung 
Gambar 3. Gambaran skematis proses top-down dan bottom-up untuk evaluasi K\&I ...................................................... 50

Gambar 4. Konsep Kerangka Kerja ...................................................... 78

Gambar 5. Proses Sertifikasi ..................................................................... 92

\section{Daftar Tabel}

Tabel 1. Contoh kebutuhan staf untuk pengujian K\&I CIFOR ..... 16

Tabel 2. Jadwal berbagai kegiatan selama pengujian lapang ........... 24

Tabel 3. Formulir 1 .................................................................... 29

Tabel 4. Agenda yang disarankan untuk lokakarya akhir ............... 54 


\section{Pendahuluan}

\subsection{TUJUAN PANDUAN INI}

Panduan ini berisi metode-metode untuk membantu pengembangan dan evaluasi kriteria dan indikator (K\&I) yang selanjutnya dapat digunakan untuk menilai kelestarian pengelolaan hutan. Berbagai metode yang disajikan dimaksudkan untuk pengembangan set K\&I untuk hutan alam pada tingkat unit pengelolaan hutan $(\mathrm{UPH})^{1}$, terutama di kawasan tropis. Panduan ini ditujukan terutama bagi para peneliti dan pengembang K\&I untuk menilai kelestarian pengelolaan hutan di kawasan tropis.

K\&I adalah perangkat yang berguna untuk membuat konsep, mengevaluasi dan mengimplementasikan pengelolaan hutan lestari. K\&I dapat diidentifikasi pada berbagai tingkat: global, regional (ekoregional), nasional dan subnasional, atau, dalam kasus ini di tingkat UPH. K\&I di tingkat nasional pada dasarnya dikembangkan sebagai perangkat untuk melaporkan dan memantau, bukan sebagai standar untuk menilai kelestarian. Di lain pihak, pengembangan K\&I pada tingkat UPH lebih banyak digunakan untuk keperluan penilaian kelestarian dan, dalam beberapa hal, sebagai perangkat untuk memudahkan implementasi kegiatan pengelolaan yang lebih baik. Tidaklah mungkin satu set K\&I dapat diterapkan dengan seragam secara global. Demikian pula, sebuah set K\&I yang dikembangkan di tingkat

1 UPH didefinisikan sebagai kawasan hutan yang batas-batasnya jelas, sebagian besar lahannya tertutup oleh hutan, dan dikelola untuk berbagai tujuan yang dinyatakan secara jelas dan didasarkan pada rencana pengelolaan jangka panjang. Lihat pembahasan UPH dalam Bab 5. 
nasional belum tentu dapat diterapkan secara tepat di tingkat unit pengelolaan hutan. Untuk itu panduan ini diberikan untuk membantu menciptakan set K\&I yang sesuai pada tingkat lokal. K\&I ini kemudian dapat digunakan untuk mengevaluasi UPH-UPH yang bersangkutan.

Berbagai metode yang disajikan dalam panduan ini dikembangkan selama berlangsungnya Proyek CIFOR tentang Pengujian Kriteria dan Indikator untuk Pengelolaan Hutan Lestari. Lokasi penelitian ini adalah di UPH-UPH yang kegiatan utamanya memproduksi kayu. Dalam panduan versi berikutnya kami akan menggabungkan pengalaman kami dengan pengujian $K \& I$ di hutan yang juga dikelola untuk tujuan lain.

Kami berharap panduan ini dapat digunakan oleh mereka yang tertarik untuk mengembangkan perangkat penilaian kualitas dan kinerja sistem-sistem pengelolaan hutan. Para pengguna dapat meliputi:

- lembaga-lembaga sertifikasi yang menilai pengelolaan HPH untuk kepentingan sertifikasi;

- para pegawai pemerintah yang merancang kebijakan yang lebih lestari untuk kehutanan dan sektor terkait lainnya;

- lembaga-lembaga pendanaan yang mengevaluasi kelestarian berbagai kegiatan yang dijalankan oleh berbagai proyek pengelolaan sumber daya alam;

- para pengelola hutan yang mengembangkan kelestarian pengelolaan mereka pada tingkat unit pengelolaan hutan;

- para pengelola proyek yang merencanakan, mengimplementasikan dan mengevaluasi proyek-proyek konservasi dan pembangunan; dan

- ilmuwan yang meneliti hubungan sebab-akibat dari segi ekologi, kehutanan dan manusia. 


\subsection{SASARAN PENGUJIAN K\&I}

Tujuan utama pengujian lapang K\&I adalah mengidentifikasi K\&I yang tepat sasaran, hemat biaya dan relevan untuk pengelolaan hutan lestari. Pengujian lapang ditujukan untuk mengidentifikasi jumlah K\&I terkecil dalam menilai pengelolaan hutan yang dapat diandalkan dengan biaya hemat.

Proses mengidentifikasi K\&I yang layak didasarkan pada evaluasi set K\&I yang ada. Jika ada kesenjangan, atau jika K\&I yang ada tidak sesuai, K\&I yang baru atau penggantinya dapat dikembangkan. Proses berulang-ulang ini melibatkan banyak stakeholder di wilayah atau negara yang bersangkutan. Berbagai metode yang diuraikan dalam panduan ini dirancang agar bersifat fleksibel namun tetap tepat. Untuk mencapai kedua hal ini tim pakar antardisiplin ilmu dilibatkan dalam suatu kerangka kerja proses iteratif yang jelas.

\subsection{RINGKASAN PROSES PENGEMBANGAN K\&I}

Kegiatan ini semata-mata ditujukan untuk pengembangan $K \& I$ di sebuah UPH tertentu. Seseorang sebaiknya tidak mencoba menghasilkan sebuah set K\&I untuk suatu wilayah selama pengujian di satu UPH sedang berlangsung. K\&I untuk suatu wilayah (contoh: beberapa UPH sejenis) akan dikembangkan dari hasil perbandingan dua atau lebih pengujian UPH. Pembandingan seperti ini akan memungkinkan pemisahan K\&I yang benar-benar spesifik lokasi dari K\&I yang lebih umum.

Jika ada sasaran tambahan, selain dari yang didefinisikan di atas, yang dipandang perlu selama dalam proses pengujian, maka kesesuaian metode-metode 
yang diuraikan dalam panduan ini sebaiknya ditinjau ulang berdasarkan konsep kerangka kerja dalam Bab 5.

Gambar 1 menunjukkan keseluruhan proses yang dilakukan CIFOR dalam pengembangan K\&I untuk pengelolaan hutan lestari di tingkat UPH. Gambar ini juga memperlihatkan letak informasi dalam panduan ini yang relevan dengan masing-masing proses.

Ringkasan proses pengembangan ini adalah:

- menjelaskan dan meninjau sasaran keseluruhan pengelolaan hutan lestari dan juga sasaran prosedur yang disajikan dalam panduan ini;

- menciptakan dan/atau mendapatkan calon set $K \& I$ sebelum pengujian lapang yang sesungguhnya;

- memilih lokasi untuk pelaksanaan pengujian K\&I;

- memilih sekelompok pakar untuk melaksanakan pengujian;

- memberi kesempatan kepada para pakar untuk melakukan kajian dan mengomentari calon K\&I;

- menyusun hasil komentar para pakar;

- menyelenggarakan suatu lokakarya para pakar untuk mendiskusikan dan menyaring calon K\&I;

- melakukan pengujian lapang calon K\&I oleh para pakar;

- menyelenggarakan suatu lokakarya para pakar untuk hasil akhir K\&I; dan

- mendokumentasikan hasil pengujian dan K\&I yang dipilih. 
Gambar 1. Diagram alir evaluasi dan proses pengembangan K\&I.

Gambar 2 di hal. 22 menyajikan tinjauan proses yang sama tetapi lebih rinci.

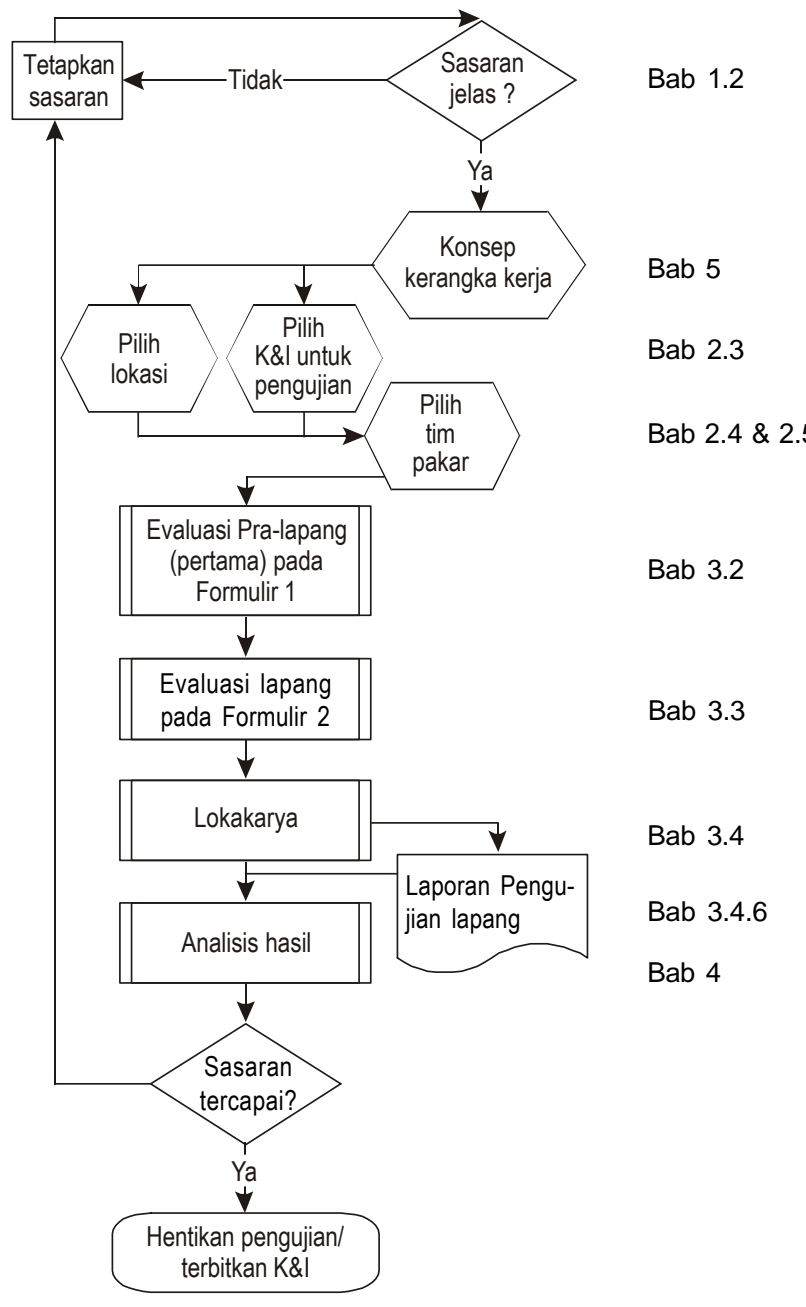




\section{Persiapan Pengujian K\&I}

\subsection{TINJAUAN KONSEP KERANGKA KERJA K\&I}

Tinjauan dan pembahasan tentang konsep kerangka kerja K\&I menjelaskan cara-cara untuk mendukung berlangsungnya pengembangan $K \& I$ yang realistis. Konsep kerangka kerja ini meliputi:

- mendefinisikan istilah-istilah utama, seperti prinsip, kriteria, dan indikator;

- menempatkan istilah-istilah tersebut dalam konteks pengelolaan hutan lestari;

- mendefinisikan berbagai kendala dalam penilaian² kelestarian;

- memudahkan penggunaan sistem K\&I dengan memperjelas hubungan hierarki dan hubungan di antara elemen-elemen yang berbeda;

- menyediakan suatu strategi untuk mengembangkan sistem penilaian yang operasional dan hemat biaya; dan

- memberi kesempatan untuk memilih K\&I yang jumlahnya paling kecil dan dapat diandalkan untuk setiap lokasi pengujian.

Konsep kerangka kerja ini menyediakan kerangka yang umum sebagai acuan bagi para pakar untuk melakukan tugas mereka. Tanpa kerangka acuan ini, kerja tim antardisiplin ilmu akan sangat sulit dan pembandingan lintas lokasi akan berisiko tinggi.

Konsep kerangka kerja yang dikembangkan oleh CIFOR disajikan dalam Bab 5. Konsep ini dikembangkan secara iteratif, berdasarkan berbagai

2 Lihat definisi 'penilaian' di hal. 89. 
interaksi selama pengujian lapang dan debat internasional tentang kelestarian. Konsep ini akan berubah, karena kelestarian sebagai konsep yang ditentukan manusia akan berkembang sesuai dengan tuntutan kebutuhan masyarakat. Jadi usulan dalam Bab 5 bukanlah hasil akhir, tetapi lebih sebagai pengulangan proses yang sedang berlangsung. Sebagai langkah pertama dalam pengembangan set $K \& I$ kami menyarankan untuk melakukan tinjauan menyeluruh tentang konsep kerangka kerja, termasuk informasi yang disajikan dalam Bab 5. Tinjauan ini sebaiknya memperhatikan juga sasaran-sasaran yang ditetapkan dan juga perkembangan terbaru dalam debat tentang kelestarian dan memodifikasi konsep kerangka kerja dan berbagai metodenya, jika diperlukan.

\subsection{LANGKAH AWAL DALAM PENYUSUNAN K\&I}

Berdasarkan pengalaman selama pengujian lapang K\&I oleh CIFOR, set $\mathrm{K} \& \mathrm{I}$ yang tepat sebaiknya mencakup hal-hal yang termasuk dalam empat kategori berikut:

- hal-hal yang sebagian besar berada di luar pengaruh UPH: kerangka kerja kebijakan, perencanaan dan undang-undang;

- dampak ekologis pengelolaan hutan; ${ }^{3}$

- dampak terhadap lingkungan sosial, termasuk dampak ekonomi; dan

\footnotetext{
3 Pernyataan ini secara tidak langsung mengabaikan dampak faktor eksternal (contoh: pencemaran udara yang merusak, atau rencana untuk pengembangan industri dan pertanian di masa depan). Faktor-faktor eksternal ini tidak dapat diabaikan dalam pertimbangan pengelolaan hutan lestari secara keseluruhan. Namun, sebagai fokus untuk mengembangkan K\&I di tingkat UPH, faktor-faktor ini jelas bersifat sekunder. Dalam keadaan tertentu, faktorfaktor eksternal ini mungkin perannya sangat menonjol sehingga mungkin harus dipertimbangkan dalam pengembangan $\mathrm{K} \& \mathrm{I}$.
} 
- K\&I yang berkaitan dengan produksi barang dan jasa; K\&I yang menyangkut kinerja keuangan mungkin termasuk di sini, jika diinginkan.

Pengujian CIFOR menunjukkan bahwa beberapa K\&I bersifat umum untuk semua lokasi di mana pengujian dilakukan. K\&I umum ini disajikan dalam Bab 8. Daftar ini dapat dipakai sebagai landasan awal untuk proses pengujian dan dapat dijadikan panduan untuk penyusunan hasil akhir.

\subsection{PEMILIHAN SET AWAL K\&I}

$\mathrm{K} \& \mathrm{I}$ yang tepat secara lokal dapat didasarkan pada satu atau lebih set awal K\&I yang ada. Set awal K\&I diperoleh dari berbagai sumber dan dapat dijadikan landasan untuk pengembangan set $K \& I$ lokal/spesifik lokasi yang terakhir. Set K\&I ini sebaiknya dipilih secara hati-hati karena pengaruhnya penting terhadap keberhasilan pengembangan set $K \& I$ yang sesuai dengan kondisi lokal.

Tiga syarat utama dalam pemilihan set awal K\&I adalah:

- set yang dipilih sebaiknya mewakili K\&I yang paling mutakhir untuk penilaian pengelolaan hutan lestari di tingkat unit pengelolaan hutan;

- sejauh mungkin, set K\&I nasional atau regional yang paling mutakhir sebaiknya dimasukkan; dan

- set yang dipilih sebaiknya mencakup kelestarian berdasarkan aspek ekologi, ekonomi dan sosial.

Sumber-sumber untuk K\&I ini termasuk:

- laporan-laporan rangkaian pengujian CIFOR;

- lembaga-lembaga sertifikasi seperti Smart Wood, Woodmark, SGSForestry/Qualifor dan SCS Inc.; 
- pemrakarsa lain seperti ITW, CSA, Greenpeace, LEI, DDB;

- organisasi-organisasi internasional dan LSM-LSM seperti FSC, ITTO, ATO, TCA, WWF, FAO, UNEP; dan

- pemrakarsa nasional atau ekoregional (contoh: Protokol Helsinki dan Protokol Montreal).

Beberapa calon set awal K\&I disajikan dalam Bab 8.

Seluruh K\&I yang ada sampai sekarang dirancang untuk menguji apakah suatu sistem pengelolaan sesuai dengan persepsi 'praktek pengelolaan terbaik' atau 'pemeliharaan hutan dengan baik'. Persepsi ini tidak sama dengan menilai kelestarian, karena pemeliharaan hutan dengan baik hanyalah suatu pernyataan tentang cara-cara paling mutakhir untuk mencapai sasaran pengelolaan hutan lestari. Dalam beberapa kasus (seperti FSC dan ITTO), pengembangan $K \& I$ bertujuan untuk dijadikan acuan untuk keperluan pengembangan lebih lanjut, daripada sebagai perangkat penilaian lapang. Dalam kasus lain (seperti TCA) tidak semua K\&I yang telah dikembangkan adalah untuk tingkat UPH. Faktor-faktor ini sebaiknya diperhatikan juga ketika memilih set awal K\&I.

Pertimbangan penting lainnya adalah jumlah K\&I dalam set awal. Memang baik sekali apabila set awal mencakup sebanyak mungkin isu-isu yang perlu dipertimbangkan dalam penilaian, tetapi biasanya ada kendala sumber daya yang sangat nyata dalam evaluasi dan pengembangan K\&I. Sebagai patokan umum kami menyarankan set awal sebaiknya tidak berisi lebih dari 250-300 K\&I pada awal pengujian. 


\subsection{PEMILIHAN LOKASI}

Sebaiknya lokasi-lokasi yang dipilih untuk pengujian K\&I sejauh mungkin mencerminkan kondisi regional dan sistem-sistem pengelolaan dalam zona yang dipilih. Lokasi ini sebaiknya mewakili contoh-contoh pengelolaan hutan di atas rata-rata. ${ }^{4}$ Suatu syarat penting dalam pemilihan lokasi adalah kemauan para pengelola hutan di tingkat nasional dan lokal untuk berpartisipasi dan bergabung dengan tim proyek. Hal ini juga akan memudahkan identifikasi K\&I umum dan spesifik lokasi melalui perbandingan hasil-hasil di lokasi-lokasi yang berbeda. Selama pengulangan pengembangan K\&I pertama kami menyarankan untuk memilih lokasi yang berada di daerah/ kawasan yang ditetapkan pemerintah sebagai hutan permanen. Untuk pengulangan pertama pilihlah lokasi yang memiliki sejarah pengelolaan yang panjang dan dokumentasi hutan yang baik, pengelolaannya dan masyarakat yang tergantung pada hutan sebaiknya diberi prioritas. Pertimbangan-pertimbangan penting lainnya adalah akses dan mobilitas ke lokasi, fasilitas akomodasi dan kerja di dalam lokasi tersebut.

\section{Catatan}

Evaluasi K\&I sebaiknya tidak dirancukan dengan evaluasi pengelolaan unit hutan di lokasi pengujian yang dipilih. Evaluasi pengelolaan adalah kegiatan yang terpisah, sebagian didasarkan pada evaluasi K\&I.

4 Secara teori, suatu lokasi pengujian yang ideal harus mencakup hutan dalam kondisi buruk, baik dan sangat baik sehingga K\&I yang diusulkan dapat diterapkan seluas mungkin dengan kondisi lapang. Dalam kenyataannya, sebagian besar lembaga pengelolaan hutan atau para pengusaha akan berusaha untuk menyajikan usaha terbaik mereka pada sekelompok orang luar yang mungkin sangat kritis. Masalah ini tidak sesulit seperti yang terlihat, karena menilai kelestarian hutan yang benar-benar dikelola dengan baik mungkin lebih sulit daripada menentukan bahwa pengelolaannya buruk. Karena itu, dengan bekerja di hutan yang baik akan mendorong tim untuk memperhatikan indikator-indikator yang sensitif. 
Pemilihan lokasi pengujian sebaiknya dilakukan setelah berkonsultasi dengan departemen-departemen pemerintah dan kelompok LSM yang terkait.

\subsection{TIM PAKAR DAN KOORDINATOR PENGUJIAN}

\subsubsection{TIMPAKAR}

\section{Pemilihan}

Sebaiknya setiap tim paling sedikit terdiri dari seorang rimbawan, seorang ekologiwan dan seorang ilmuwan sosial. Jumlah anggota tim dapat bervariasi antara tiga sampai enam orang tergantung pada sumber daya yang tersedia. Pengalaman kami menunjukkan bahwa evaluasi K\&I yang efektif dapat dicapai oleh tiga orang anggota tim, tetapi jumlah yang lebih besar akan lebih memungkinkan untuk pemilihan K\&I dengan yang lebih baik karena:

- jika seorang anggota dari tim yang terdiri dari tiga orang tidak bisa berperan karena sesuatu hal, tim ini tidak dapat lagi bekerja;

- tim yang terdiri dari enam anggota akan lebih baik untuk berlangsungnya diskusi; dan

- tim yang lebih besar memberi kesempatan bagi disiplin ilmu, kelembagaan atau pandangan pribadi untuk dapat dimasukkan.

Selama rangkaian pengujian CIFOR susunan tim umumnya melibatkan tiga anggota yang direkrut secara internasional dan dua dari negara asal. Walaupun pelibatan anggota bereputasi internasional tidak terlalu penting, kami menyarankan paling sedikit seorang pakar bereputasi internasional dengan keahlian yang sesuai dimasukkan dalam tim, supaya dapat memberikan perspektif eksternal. Orang luar kadang memiliki kebebasan menanyakan masalah tentang kebijakan atau program yang enggan diungkapkan oleh konsultan lokal. 
Perekrutan pakar dalam bidang yang sesuai perlu benar-benar diusahakan, baik dalam hal disiplin ilmu maupun lokasi yang terkait. Sejauh mungkin keragaman jender diusahakan. Penting juga memasukkan perspektif yang berbeda ke dalam tim (contoh: para akademisi, konsultan, LSM, pegawai pemerintah). Tim sebaiknya tidak mewakili kelompok 'orang dalam', yang sangat mengenal satu sama lain dan memiliki pandangan yang hampir sama. Situasi seperti ini dapat mengurangi keragaman pendapat dan kualitas diskusi pada saat evaluasi K\&I. Hasilnya, kesempatan untuk memasukkan K\&I baru dan penting mungkin akan hilang.

Anggota tim sebaiknya:

- mengetahui dengan baik semua perkembangan mengenai pengelolaan hutan lestari di lapangan, juga berperan sebagai nara sumber bagi tim menurut bidang spesialisasi masing-masing;

- memiliki pemahaman yang baik tentang perdebatan terbaru dalam mengevaluasi kelestarian dan sertifikasi;

- berpengalaman dan siap bekerja dengan tim antardisiplin ilmu di bawah koordinasi pemimpin tim dan koordinator tim;

- mematuhi prosedur yang telah ditetapkan untuk pengujian;

- memiliki pengetahuan yang cukup tentang bahasa lokal; dan

- memiliki pengetahuan yang cukup tentang kondisi kehutanan di wilayah UPH yang diteliti.

Kami menyarankan pentingnya menggunakan tim yang berbeda untuk lokasi yang berbeda, terutama jika sasarannya adalah identifikasi K\&I umum dan juga K\&I spesifik lokasi.

\section{Pemimpin Tim}

Tugas utama pemimpin tim adalah memudahkan kerja tim antardisiplin ilmu 
dan menyusun laporan akhir sebagai kesimpulan pengujian. Kami merekomendasikan pendekatan rekan sejawat untuk kerja tim, pemimpin tim bertanggung jawab untuk memastikan agar masukan semua disiplin ilmu dari anggota tim diberi bobot yang sama dalam pertimbangan dan kesimpulan akhir. Pemimpin tim dapat juga membantu koordinator dalam hal-hal pengorganisasian atau administrasi, dan memastikan segala sesuatu berjalan dengan baik.

Pemimpin tim sebaiknya dipilih dari tim pakar.

\section{Konsep Tim $^{5}$}

Tim harus berperan sebagai unit antardisiplin ilmu yang terpadu untuk mengevaluasi pemilihan kriteria dan indikator. Untuk mencapainya, anggota tim perlu:

- memaksimumkan pertukaran informasi baik secara informal dan secara lebih formal dalam pertemuan sehari-hari, diskusi tim dan lokakarya;

- melakukan berbagai tugas baik di dalam maupun di luar bidang spesialisasi; dan

- berperan aktif dan kreatif dalam setiap diskusi dan lokakarya.

Hasil pengujian CIFOR menyimpulkan bahwa:

- komposisi tim berdasarkan pengalaman dan latar belakang keahlian sangat penting;

- pemimpin tim sebaiknya tidak terlalu dominan, tetapisebaiknya berusaha mendorong partisipasi dan kerjasama semua anggota tim;

5 Ide untuk meningkatkan kerja tim, lihat Bab 3.3.5. 
- perasaan yang sama untuk saling berbagi tanggung jawab dan kemauan untuk mendiskusikan dan mencapai konsensus tanpa harus terlalu berselisih faham juga sangat penting;

- pemahaman yang jelas tentang konsep adalah penting;

- waktu total yang diperlukan paling sedikit 20 hari, termasuk kerja di belakang meja dan di lapang;

- tinjauan bersama untuk seluruh K\&I, dua sampai tiga kali selama masa pengujian, terbukti sangat bermanfaat untuk menjamin interaksi di antara anggota tim dan juga saling membagikan pemahaman masing-masing yang semakin meningkat mengenai kondisi lokal;

- pemahaman yang jelas tentang strategi yang digunakan dalam mengevaluasi K\&I sangat meningkatkan keefektifan tim dan harus berdasarkan konsensus di antara anggota tim - salah satu bahaya adalah terperangkap dalam definisi istilah-istilah tertentu sementara yang diperlukan adalah konsensus umum; dan

- tim yang paling berhasil telah mengadopsi pendekatan analisis sistem dari awal, memahami bahwa UPH lokal dan lingkungan di sekitarnya sebagai sistem terpadu, yang masing-masing komponennya saling berhubungan.

Selain tim pakar dan koordinator proyek, pakar lain mungkin diperlukan dari waktu ke waktu. Para pakar ini tidak akan mengevaluasi K\&I sendiri, tetapi akan membantu anggota tim pakar dalam memahami isu-isu atau memberikan interpretasi yang dapat diandalkan tentang situasi dan kecenderungan tertentu. Mereka biasanya juga turut serta dalam lokakarya pengujian. Staf pendukung tambahan untuk menangani logistik kegiatan pengujian juga diperlukan. Kami memberikan contoh kebutuhan staf untuk kegiatan pengujian CIFOR dalam Tabel 1. 


\section{Tabel 1. Contoh kebutuhan staf untuk pengujian K\&I CIFOR.}

\begin{tabular}{|c|c|c|c|}
\hline & Indonesia & Pantai Gading & Brazil \\
\hline $\begin{array}{l}\text { Lama } \\
\text { Pengujian } \\
\text { (tahap lapang) }\end{array}$ & 34 hari & 34 hari & 34 hari \\
\hline Tim Pakar & $\begin{array}{l}5 \text { anggota: } \\
3 \text { rimbawan, } \\
1 \text { ekologiwan, } \\
1 \text { antropologiwan }\end{array}$ & $\begin{array}{l}5 \text { anggota: } \\
2 \text { rimbawan, } \\
1 \text { ekologiwan, } \\
2 \text { sosiolog }\end{array}$ & $\begin{array}{l}5 \text { anggota: } \\
3 \text { rimbawan, } \\
1 \text { ekologiwan, } \\
1 \text { sosiolog }\end{array}$ \\
\hline $\begin{array}{l}\text { Koordinator } \\
\text { Pakar Lain }\end{array}$ & $\begin{array}{l}\text { ya } \\
4 \\
1 \text { rimbawan, } \\
1 \text { ekologiwan, } \\
1 \text { antropologiwan, } \\
1 \text { pengelola sumber } \\
\text { daya alam }\end{array}$ & $\begin{array}{l}\text { ya } \\
3 \\
2 \text { rimbawan, } \\
1 \text { antropologiwan }\end{array}$ & $\begin{array}{l}\text { ya } \\
2 \\
1 \text { rimbawan, } \\
1 \text { antropologiwan }\end{array}$ \\
\hline Staf & 4 & 3 & 2 \\
\hline $\begin{array}{l}\text { Pendukung } \\
\text { Lain }\end{array}$ & $\begin{array}{l}1 \text { asisten proyek, } \\
3 \text { asisten peneliti }\end{array}$ & $\begin{array}{l}1 \text { asisten proyek, } \\
2 \text { asisten peneliti }\end{array}$ & $\begin{array}{l}1 \text { asisten proyek, } \\
1 \text { asisten peneliti }\end{array}$ \\
\hline $\begin{array}{l}\text { Staf Jangka } \\
\text { Pendek }\end{array}$ & $\begin{array}{l}\text { Sekretaris, kru lapang, } \\
\text { dll. }\end{array}$ & $\begin{array}{l}\text { Sekretaris, kru lapang, } \\
\text { dll. }\end{array}$ & $\begin{array}{l}\text { Sekretaris, kru lapang, } \\
\text { dll. }\end{array}$ \\
\hline
\end{tabular}

\subsubsection{KOORDINATOR PENGUJIAN K\&I}

Koordinator penting peranannya dalam menjalankan pengujian $K \& I$. Koordinator ini bisa salah seorang anggota yang secara khusus dipilih dari tim pakar, tetapi biasanya adalah anggota staf dari lembaga yang terkait dalam menentukan set K\&I yang baru. Secara umum, koordinator pengujian memberikan informasi latar belakang kepada tim, menjamin bahwa proses pengujian berjalan lancar, dan menerima laporan akhir dari tim untuk analisis lebih lanjut dan aksi berikutnya. Secara lebih spesifik, tanggung 
jawab koordinator adalah sebagai berikut.

- Pengembangan perencanaan dan metode: pengembangan/adaptasi panduan ini lebih lanjut untuk sasaran yang dipilih. ${ }^{6}$ Ia akan merencanakan dan bertanggung jawab terhadap pelaksanaan pengujian, tetapi untuk menghindari bias biasanya bukan seorang anggota tim pengujian.

- Pemilihan lokasi: pemilihan lokasi berdasarkan konsultasi dengan kelompok penasihat yang relevan dan mitra organisasi.

- Pemilihan anggota tim: pemilihan tim pakar berdasarkan konsultasi dengan kelompok penasihat dan orang serta lembaga yang relevan.

- Koordinasi dan kelancaran pengujian: koordinasi seluruh kegiatan sehubungan dengan pengujian kriteria dan indikator. Ia diharapkan akan mendampingi tim pengujian di lapang untuk memastikan interpretasi sasaran dan berbagai metode dengan tepat dan untuk memudahkan kerja anggota tim. Koordinator perlu mengerti peran gandanya sebagai 'pemandu' dan 'penyedia jasa'.

- Komunikasi, analisis dan penulisan laporan: komunikasi status dan hasil dari kegiatan pengembangan K\&I pada anggota tim, peserta lokakarya, lembaga yang mengharapkan pengembangan $K \& I$, dan kemudian sampai kelompok yang tertarik lainnya.

- Kolaborasi dengan mitra organisasi: melalui pengujian dengan cara bekerjasama dengan semua mitra organisasi yang relevan. Kerjasama ini memerlukan cukup banyak ketrampilan hubungan antarpribadi.

6 Sasaran-sasaran yang ditetapkan mungkin berubah, contohnya, jika tujuan pengujian dimodifikasi untuk menciptakan set K\&I untuk pengelolaan hutan untuk HHNK, hutan yang dikelola oleh masyarakat, atau untuk K\&I di tingkat nasional atau regional. Perubahan sasaran ini mungkin memerlukan perubahan berbagai metode yang digunakan. 


\subsubsection{URAIAN RINGKAS BAGI TIM}

\section{Mengembangkan Dokumen Uraian Ringkas}

Agar tidak terlalu membebani tim pakar dengan informasi yang tidak perlu, maka perlu disiapkan 'dokumen uraian ringkas' untuk memandu mereka melalui proses evaluasi. Dokumen uraian ringkas ini umumnya disiapkan oleh koordinator pengujian K\&I bekerjasama dengan lembaga-lembaga yang menginginkan K\&I yang baru.

Dokumen ini sebaiknya:

- menyajikan deskripsi secara jelas tentang sasaran, berbagai metode dan proses pengujian $K \& I$ di lokasi lapang;

- berisi seluruh K\&I dalam set awal K\&I untuk dievaluasi;

- menyediakan informasi tentang lokasi itu sendiri;

- berisi kutipan-kutipan yang paling relevan, tentang rencana pengelolaan, produksi, statistik pendapatan dan masukan, informasi vegetasi dan ekologi yang terkait, informasi demografi penduduk yang tinggal di atau di sekitar UPH dan peta wilayah (dalam Lampiran); dan

- dikirimkan kepada tim pakar paling lambat tiga minggu sebelum pengujian, sehingga mereka lebih mengenal lokasi pengujian.

\section{Lokakarya Uraian Ringkas}

Jika mungkin, sebaiknya adakan lokakarya persiapan awal agar anggota tim saling mengenal satu sama lain dan untuk proses pengujian dan pengembangan K\&I. Lokakarya ini sebaiknya diadakan sebelumnya agar tim melengkapi Formulir 1. Jika ini tidak mungkin, maka koordinator pengujian sebaiknya memastikan bahwa anggota tim mengenal proses secara keseluruhan dan bahwa proses ini dikaji pada setiap awal tahap pengujian lapang. 


\section{Prosedur Pengujian K\&I}

\subsection{IKHTISAR BERBAGAI METODE}

Pengujian lapang K\&I terdiri dari tiga tahap, yang diperlakukan sebagai tiga filter (Gambar 2) terpisah. Perlu diperhatikan bahwa proses ini bukan sekedar penyaringan secara mekanis. Secara eksplisit proses ini membuka kesempatan bagi masukan dan modifikasi kriteria dan indikator secara kreatif, asal masukanmasukan ini juga harus dievaluasi.

- Filter No. 1: Tahap pra-kerja lapang sesuai dengan hasil yang diperoleh dari 'Formulir 1': Selama proses penyaringan pertama ini para pakar akan mengevaluasi kriteria dan indikator secara terpisah, menggunakan 'Formulir 1' sebagai filter utama mereka (lihat Bab 3.2 untuk deskripsi Formulir 1 dan penggunaannya). Kegiatan ini pada dasarnya dilakukan di belakang meja untuk melaksanakan evaluasi awal terhadap seluruh K\&I dalam set awal K\&I yang dipilih. Menjelang akhir tahap ini, anggota tim pakar pertama kali akan bertemu untuk menyusun dan mengklasifikasikan hasil evaluasi K\&I mereka dari Formulir 1.

- Filter No. 2: Tahap pra-kerja lapang sesuai dengan hasil yang diperoleh dari 'Formulir 2': Setelah selesai penyaringan pertama calon K\&I (Filter 1), kegiatan selanjutnya adalah tahap kerja tim antardisiplin ilmu di dan dekat UPH. Secara intelektual, tahap ini mewakili sebuah pengulangan siklus pendekatan induktif dan deduktif, sambil anggota tim menerapkan pengetahuan mereka ke $K \& I$, lalu menguji kesimpulan mereka dengan kenyataan lapang dan pandangan kolega mereka, kembali ke evaluasi ulang K\&I dengan perkembangan pengetahuan mereka, dalam proses yang berulang. 
Anggota tim mengisi formulir penilaian dengan melihat setiap K\&I yang dipilih (Formulir 2) dan bertukar informasi dan pandangan dengan wakilwakil disiplin ilmu lainnya. Deskripsi Formulir 2 dengan contoh cara penggunaannya diberikan dalam Bab 3.3 (lihat lampiran 8.2). Satu dari perangkat utama untuk evaluasi adalah set sembilan ciri (Bab 5.3.1) yang dijadikan dasar untuk menilai K\&I. Gambar 2 menunjukkan bahwa proses evaluasi keseluruhan sangat kompleks dan anggota tim memerlukan 'sumber daya statis' (seperti 'data lokasi' atau 'pengetahuan pakar' dalam Gambar 2) untuk mendukung proses yang dinamis untuk memeriksa, menguji dan merevisi calon K\&I. Proses keseluruhan bersifat pengulangan, di mana kendala utamanya adalah waktu. Pemeriksaan akhir terhadap kesimpulan anggota tim berlangsung pada penutupan lokakarya.

- Filter No. 3: Tahap pasca-kerja lapang-lokakarya: Setelah pengujian lapang dan modifikasi calon K\&I (Filter No. 2) proses berlanjut ke tahap diskusi/modifikasi (Filter No. 3) di mana anggota tim mendiskusikan K\&I yang diusulkan bersama peserta lain (lihat Bab 3.4). Peserta baru pada penutupan lokakarya diundang dari lembaga dan latar belakang disiplin ilmu yang berbeda, tetapi semua dilengkapi dengan pengetahuan dan minat mereka terhadap pengelolaan hutan lestari. Lokakarya ini sebaiknya berlangsung selama sekitar tiga hari.

Selama lokakarya, diskusi yang berlangsung dalam kelompok-kelompok kerja yang diberi tugas untuk meninjau usulan-usulan yang diajukan oleh tim yang terlibat. Kelompok ini memiliki dua tujuan. Pertama, memberikan tinjauan rekan sejawat (peer review) terhadap pekerjaan anggota tim dan juga karena peserta lokakarya biasanya lebih luas lingkupnya daripada UPH yang dipilih. Lokakarya juga memberikan kesempatan pertama untuk 
mengetahui derajat aplikasi yang lebih luas untuk K\&I yang diusulkan oleh tim.

Akhirnya anggota tim akan merangkum pengalaman dan kesimpulan mereka dalam laporan, memasukkan rekomendasi-rekomendasi yang diperoleh dalam lokakarya. Hasil ini kemudian disampaikan kepada koordinator, untuk diperiksa dan dievaluasi, secara kualitatif maupun kuantitatif.

Kegiatan lanjutan setelah lokakarya akan ditentukan sesuai kebutuhan organisasi yang melakukannya. Kemungkinan organisasi-organisasi ini berharap akan membuat set K\&I yang baru ke dalam bentuk yang dapat digunakan oleh para penilai di hutan yang diidentifikasi. Tindakan lanjutan lainnya mungkin menyerahkan K\&I kepada para donor, pemerintah nasional atau proyek khusus yang berkepentingan.

Dalam Tabel 2 (Bab 3.2) kami menyajikan kerangka waktu yang tepat untuk berbagai kegiatan yang berkaitan dengan pengujian lapang $K \& I$ di lokasi tertentu selama CIFOR melakukan pengujian. 
Gambar 2. Diagram alir berbagai metode yang digunakan untuk mengevaluasi $K \& I$ selama pengujian berlangsung.

Penjelasan berbagai proses dijelaskan dalam teks.

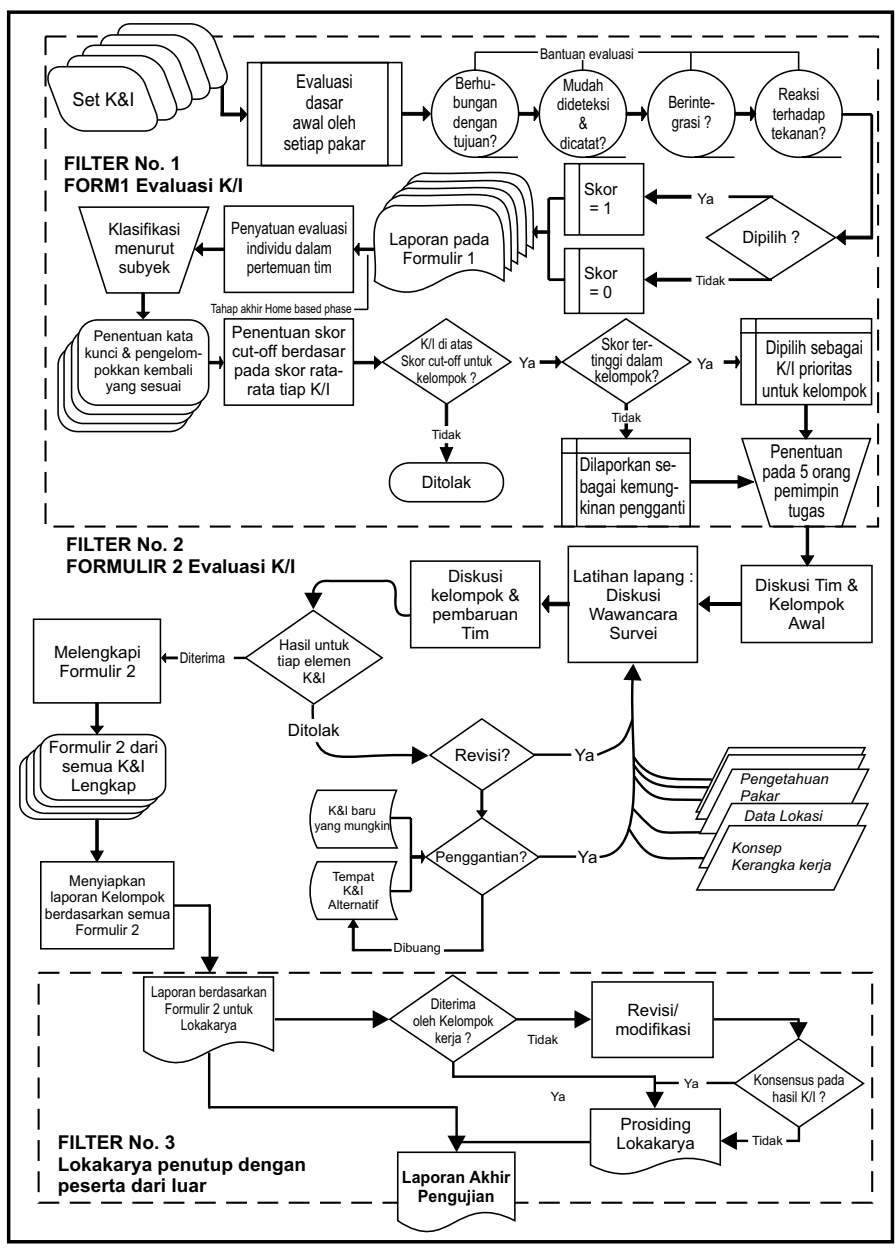




\subsection{EVALUASI PRA-LAPANG K\&I: FILTER NO. 1}

\subsubsection{TUJUAN FILTER NO. 1}

Filter No. 1 bertujuan untuk mengevaluasi seluruh set K\&I awal dan menentukan yang paling penting dalam menilai kelestarian hutan, berdasarkan penilaian profesional terbaik. Pengujian pertama terhadap calon $K \& I$ ini difokuskan untuk menyisihkan K\&I yang jelas kurang baik. Hasil evaluasi ini selanjutnya akan didiskusikan dengan anggota tim lainnya waktu tim berkumpul untuk pertama kalinya (lihat Tabel 2). Saat pertemuan pertama tim akan menentukan bagian K\&I yang dapat dianggap 'prioritas', pantas untuk dievaluasi lebih lanjut dan lebih rinci.

Filter No. 1 menggunakan Formulir 1 untuk mengevaluasi seluruh K\&I. Pengisian Formulir 1 berlangsung pada waktu persiapan di tempat masingmasing pakar. Seluruh hasil Formulir 1 ditinjau dan dibandingkan pada awal pengujian lapang K\&I di UPH yang akan diteliti. Di sana anggota tim pakar akan bekerja bersama menggunakan hasil evaluasi masing-masing melalui Formulir 1 untuk mengembangkan subset K\&I (lihat Gambar 2 dan Tabel 2). Subset ini akan menyajikan pendapat para pakar tentang K\&I yang paling penting untuk menilai pengelolaan hutan lestari di lokasi yang diteliti. Data dari Formulir 1 adalah dasar set awal K\&I untuk lokasi yang bersangkutan sebelum pengujian lapang dilaksanakan.

\subsubsection{PENGANTAR UNTUK FORMULIR 1}

Formulir 1 menggunakan lima pertanyaan berikut yang memfokuskan pada sifat-sifat penting kriteria dan indikator, dan untuk memudahkan penyisihan K\&I yang kurang baik (lihat Bab 5.3.1 untuk diskusi yang lebih lengkap tentang empat sifat pertama). 
1. Sangat erat kaitannya dan berhubungan dengan sasaran penilaian? Secara langsung/jelas/berdasarkan intuisi/terkait secara logis dengan kriteria kelestarian

2. Mudah dideteksi, dicatat dan ditafsirkan? Mudah mendapatkan informasi, yang terus terang?

3. Memberikan ringkasan atau langkah-langkah terintegrasi? Meringkas/ memadukan banyak informasi, apakah informasi itu efisien?

4. Respon yang memadai terhadap perubahan tingkat tekanan? Apakah indikator ini dapat memberikan Anda informasi yang berguna dan penting untuk berbagai situasi?

\section{Tabel 2. Jadwal berbagai kegiatan selama pengujian lapang.}

Perhatikan bahwa waktu yang disajikan pada hari penutup ' $F$ ' yaitu hari ke-65 dalam pengujian. Kami merekomendasikan sekitar 65 hari. Namun, jika mungkin pengujian sebaiknya diselesaikan dalam waktu 20 hari dalam kondisi yang ideal.

\begin{tabular}{|llll|}
\hline Tahap & Kegiatan & Batas waktu & Keterangan \\
\hline $\begin{array}{l}\text { Filter } \\
\text { No. 1 }\end{array}$ & $\begin{array}{l}\text { Buku uraian ringkas } \\
\text { kepada anggota tim }\end{array}$ & $\begin{array}{l}\text { Tanggal mulai: Tanggal } \\
\text { terakhir ('F') - 65 hari }\end{array}$ & $\begin{array}{l}\text { Buku uraian ringkas } \\
\text { berisi berbagai metode, } \\
\text { TOR dan formulir- } \\
\text { formulir. }\end{array}$ \\
& $\begin{array}{lll}\text { Uraian ringkas anggota } \\
\text { tim pertama oleh staf }\end{array}$ & Kira-kira F - 50 hari & $\begin{array}{l}\text { Sasaran: menandai K\&I } \\
\text { yang dipilih dan yang } \\
\text { ditolak. }\end{array}$ \\
& $\begin{array}{lll}\text { proyek } \\
\text { Evaluasi dalam set dasar } \\
\text { di tempat pakar masing- } \\
\text { masing K\&I }\end{array}$ & Kira-kira F - 35 hari & \\
\cline { 2 - 4 } & Kedatangan anggota tim & F - 30 hari & \\
di tempat pertemuan & & \\
\hline
\end{tabular}




\begin{tabular}{|c|c|c|c|}
\hline & \multirow{2}{*}{$\begin{array}{l}\text { Pembandingan dan } \\
\text { pemeriksaan hasil dari } \\
\text { Formulir } 1 \\
\text { Penilaian K\&I untuk tiap } \\
\text { peminpin tugas }\end{array}$} & \multicolumn{2}{|l|}{ F - 29 sampai F - 28} \\
\hline & & F -27 & \\
\hline & $\begin{array}{l}\text { Mengelompokkan K\&I } \\
\text { menurut kata kunci, } \\
\text { identifikasi tumpang } \\
\text { tindih, penentuan skor } \\
\text { pembatas dan pemilihan } \\
\text { K\&I prioritas }\end{array}$ & F - 27 sampai F - 26 & $\begin{array}{l}\text { Pada tahap ini kira-kira } \\
25 \% \text { dari } 1100 \mathrm{~K} \& \mathrm{I} \text { telah } \\
\text { ditolak, kira-kira } 10 \% \\
\text { yang dipilih sebagai } \\
\text { 'prioritas' dan sisanya } \\
\text { disimpan sebagai 'peng- } \\
\text { ganti' (lihat Gambar 2). }\end{array}$ \\
\hline \multirow[t]{4}{*}{$\begin{array}{l}\text { Filter } \\
\text { No. } 2\end{array}$} & $\begin{array}{l}\text { 1. Masukkan K\&I dari } \\
\text { Formulir } \\
\text { 2. Pertemuan dengan } \\
\text { pembuat kebijakan, } \\
\text { lembaga-lembaga } \\
\text { pengatur dan pemberi } \\
\text { pengaruh pada kebi- } \\
\text { jakan }\end{array}$ & F - 25 sampai F - 22 & $\begin{array}{l}\text { Diskusi ini biasanya ber- } \\
\text { peran pada tingkat nasio- } \\
\text { nal dan ibukota wilayah, } \\
\text { propinsi atau kabupaten } \\
\text { yang relevan. Diskusi ini } \\
\text { sangat penting dalam } \\
\text { rangka menjelaskan } \\
\text { kerangka rujukan untuk } \\
\text { pengelolaan dan kerja- } \\
\text { sama pembentukan an- } \\
\text { tardisiplin ilmu. }\end{array}$ \\
\hline & Evaluasi lapang di UPH & F - 21 sampai F - 7 & $\begin{array}{l}\text { Selama tahap ini peng- } \\
\text { ujian K\&I yang men- } \\
\text { jalani perubahan paling } \\
\text { kualitatif, walau jum- } \\
\text { lahnya mungkin tidak } \\
\text { banyak berubah. }\end{array}$ \\
\hline & Diskusi $\mathrm{K} / \mathrm{I}$ tim formal & $\begin{array}{l}\text { Setiap hari ketiga } \\
\text { sam-pai keempat pada } \\
\text { F - } 21 \text { sampai F - } 7\end{array}$ & $\begin{array}{l}\text { Partisipasi tidak terbatas } \\
\text { hanya untuk anggota tim } \\
\text { proyek dan pakar. Para } \\
\text { pengelola hutan dan } \\
\text { stakeholder lain diun- } \\
\text { dang untuk berpartisipasi } \\
\text { dalam beberapa hal. }\end{array}$ \\
\hline & $\begin{array}{l}\text { Pengumpulan hasil di- } \\
\text { dasarkan evaluasi For- } \\
\text { mulir } 2\end{array}$ & F - 6 sampai F - 4 & $\begin{array}{l}\text { Persiapan untuk penu- } \\
\text { tupan Lokakarya. Hanya } \\
\text { untuk anggota tim dan } \\
\text { proyek. }\end{array}$ \\
\hline
\end{tabular}




\begin{tabular}{|llll|}
\hline $\begin{array}{l}\text { Filter } \\
\text { No. 3 }\end{array}$ & Lokakarya penutup & F - 3 sampai F - 1 & $\begin{array}{l}\text { Merupakan tahap akhir } \\
\text { dari setiap pengujian } \\
\text { dan satu-satunya terha- } \\
\text { dap K\&I yang paling } \\
\text { penting. Modifikasi dan } \\
\text { penolakan diijinkan. }\end{array}$ \\
& & & $\begin{array}{l}\text { Hanya anggota tim dan } \\
\text { proyek. }\end{array}$ \\
\cline { 2 - 5 } & $\begin{array}{l}\text { Tinjauan pengujian, pe- } \\
\text { nyelesaian laporan }\end{array}$ & F (Hari terakhir) & \\
\cline { 2 - 5 } & Keberangkatan tim & $F+1$ & Hanya oleh pemimpin tim. \\
\cline { 2 - 4 } \\
\cline { 2 - 4 }
\end{tabular}

Pertanyaan-pertanyaan tersebut ditambah pertimbangan-pertimbangan lain yang diberikan di bawah ini mengantar pada pertanyaan kelima:

5. Apakah butir ini penting dan karena itu dipilih sebagai 'prioritas'? Apakah butir ini relevan dan tepat? Apakah berguna? Apakah membutuhkan investigasi lebih lanjut pada tahap pengujian lapang?

Perlu diperhatikan bahwa suatu kriteria atau indikator tidak harus memiliki skor yang tinggi pada pertanyaan 1-4 untuk dipilih sebagai K\&I 'prioritas' (Pertanyaan5). Misalnya, prinsip dan kriteria akan selalu memiliki skor yang relatif rendah pada Pertanyaan 2, dibandingkan dengan indikator dan pengukur. Karena itu pemilihan akhir tidak hanya didasarkan pada skor ratarata Pertanyaan 1-4. Elemen tambahan berupa pertimbangan keputusan sesuai keahlian pakar akan selalu diperlukan.

Hal-hal berikut akan sangat berguna dalam memandu keputusan akhir untuk Pertanyaan 5:

- Apakah kriteria dan indikator akan dievaluasi dalam konteks kondisi di UPH atau di negara yang bersangkutan?

- Apakah kriteria/indikator penting untuk penilaian kelestarian? 
- Apakah motivasi di belakang kriteria atau indikator? Apakah ini menjadi perhatian selama evaluasi?

- Apakah ada cara yang lebih baik dalam mengekspresikan kriteria atau indikator?

- Persiapkan untuk merumuskan kriteria dan indikator baru setelah berbagai kekurangannya dikenali.

- Apakah mungkin menyarankan batas yang lebih tinggi atau lebih rendah untuk kriteria atau indikator yang diteliti?

- Berikan pilihan pada kriteria dan indikator yang lebih mudah diukur dan lebih mudah dipahami.

- Ingat keperluan untuk menetapkan set kriteria dan indikator minimum.

- Carilah beberapa kriteria dan indikator yang terintegrasi daripada yang jumlahnya banyak tetapi terpisah-pisah.

\subsubsection{MENGGUNAKAN FORMULIR 1}

Untuk memudahkan analisis dan menghemat waktu, kami menyarankan agar data untuk Formulir 1 (Tabel 3) dicatat langsung ke dalam komputer dengan format yang mudah digunakan kembali. Selama pengalaman pengujian CIFOR, lembar isian Microsoft Excel ternyata yang paling sesuai.

Instruksi untuk Formulir 1:

Kolom 1 - Sumber: Masukkan sumber dari K\&I (contoh: Smartwood, Pengujian CIFOR Pantai Gading, FSC). Akan sangat bermanfaat untuk mendefinisikan kode ringkas untuk setiap set dasar yang dipilih.

Kolom 2 - No. K/I seperti yang dicetak dalam dokumen sumber: Biasanya semua K\&I dalam set dasar akan diberi kode atau dinomori. Nomor ini sebaiknya dimasukkan untuk memungkinkan identifikasi kembali di 
kemudian hari. Koordinator pengujian sangat disarankan untuk mengembangkan sistem penomoran untuk set awal K\&I tersebut yang belum diberi nomor.

Kolom 3 - Kelas: Ketika mengevaluasi K\&I, pakar sebaiknya membuat klasifikasi (reklasifikasi) K\&I dalam dokumen sumber menurut lima kategori berikut, dan menggunakan kode kelompok yang tepat yang ditunjukkan di sini:

P : Kerangka kerja kebijakan, perencanaan dan legal

$S$ : Dampak sosial

$\mathrm{M}$ : Kegiatan kehutanan, produksi barang dan jasa

E : Dampak ekologis

F : Aspek keuangan/finansial dan ekonomi

Kegunaan kode tersebut adalah untuk memudahkan pengurutan K\&I ke dalam kelompok-kelompok ini selama proses pemilihan K\&I 'prioritas'.

Kolom 4-7: Gunakanlah skala 1-5 untuk menjawab pada kolom-kolom ini di mana:

$1=$ buruk $2=$ sedang $3=$ memuaskan $4=$ baik $5=$ baik sekali

Kolom 8 - Penting dan karena itu dipilih sebagai 'prioritas': Waktu menjawab kolom ini para pakar perlu mengevaluasi jawaban-jawaban yang diberikan dalam empat kolom sebelumnya, ingat panduan yang diberikan di atas dan kegunaan Filter No. 1.

Jawaban dalam kolom 8 sebaiknya hanya:

$$
\begin{aligned}
& 0=\text { tidak diterima untuk evaluasi lebih lanjut } \\
& 1=\text { diterima untuk evaluasi lebih lanjut }
\end{aligned}
$$


Tabel 3. Formulir 1.

\begin{tabular}{|c|c|c|c|c|c|c|c|}
\hline \multicolumn{8}{|c|}{ Formulir 1: Evaluasi semua kriteria dan indikator } \\
\hline Sumber & $\begin{array}{l}\text { No. K/I yang } \\
\text { dicetak dalam } \\
\text { dokumen } \\
\text { sumber }\end{array}$ & Kelompok & $\begin{array}{l}\text { Sangat erat } \\
\text { kaitannya } \\
\text { dan ber- } \\
\text { hubungan } \\
\text { dengan } \\
\text { sasaran } \\
\text { penilaian? }\end{array}$ & \begin{tabular}{|l|} 
Mudah \\
dideteksi, \\
dicatat dan \\
ditafsirkan?
\end{tabular} & $\begin{array}{l}\text { Memberikan } \\
\text { pengukuran } \\
\text { yang } \\
\text { ringkas dan } \\
\text { terin- } \\
\text { tegrasi? }\end{array}$ & \begin{tabular}{|l} 
Respon \\
yang \\
memadai \\
terhadap \\
perubahan \\
tingkat \\
tekanan?
\end{tabular} & $\begin{array}{l}\text { Penting } \\
\text { dan karena } \\
\text { itu dipilih } \\
\text { sebagai } \\
\text { 'prioritas' } \\
\text { Ya=1 } \\
\text { Tidak }=0\end{array}$ \\
\hline 1 & 2 & 3 & 4 & 5 & 6 & 7 & 8 \\
\hline & & & & & & & \\
\hline & & & & & & & \\
\hline & & & & & & & \\
\hline
\end{tabular}

\subsubsection{TABULASI DAN ANALISIS HASIL}

Setelah semua K\&I dalam set dasar yang dipilih dan telah dievaluasi oleh semua pakar, pertemuan pertama tim akan dilangsungkan di bawah panduan koordinator. Selama pertemuan 1-2 hari ini, hasil Formulir 1 akan disusun dan dianalisis. Langkah-langkah dalam proses ini adalah sebagai berikut:

- Respon/jawaban semua pakar tersebut disusun dalam satu lembar isian Excel.

- Dua kolom pertama dalam Formulir 1 akan digunakan untuk mencocokkan jawaban pakar.

- Rata-rata Kolom 8 ('yang dipilih') akan dihitung untuk semua baris ke dalam tabel yang lebih terinci. Kolom ini dapat disebut 'Pilihan Ratarata'.

- Pada tahap ini tabel perlu disortir menggunakan petunjuk pemilahan sebagai berikut: (1) Kolom 3, (2) Kolom 1, (3) Kolom 2.

- Ketidak-konsistenan dalam klasifikasi K\&I ke dalam lima kategori untuk Kolom 3 sebaiknya dipecah pada tahap ini. 
- Penyortiran kedua dilakukan menggunakan petunjuk berikut: (1) Kolom 3, (2) 'Pilihan Rata-rata' (secara menurun), (3) Kolom 1, (4) Kolom 2.

- Sebagai hasil langkah ke-6 tabel sekarang dibagi menjadi lima bagian berdasarkan kelompok (P, M, E, S dan F), dengan hasil dalam 'Pilihan Rata-rata' urutannya menurun.

- Kelima bagian ini kemudian dibagi di antara para pakar sesuai latar belakang disiplin ilmu mereka masing-masing.

- Para pakar akan menganalisis bagian ini untuk menentukan titik pembatas, $K \& I$ yang berada di bawahnya tidak akan diterima untuk evaluasi lebih lanjut.

- Para pakar sekarang menganalisis kata kunci untuk menguraikan isi setiap K\&I dalam bagian yang dialokasikan untuk mereka.

- Kata kunci digunakan untuk membuat kelompok (dan subkelompok) K\&I yang sama dalam setiap kelompok.

- Menggunakan skor dalam kolom 'Pilihan Rata-rata', para pakar memilih perwakilan terbaik dalam setiap kelompok/subkelompok sebagai K\&I 'prioritas' pengujian lapang selanjutnya. K\&I sisanya dalam kelompok/ subkelompok itu disimpan juga sebagai K\&I 'pengganti', asalkan nilainya di atas titik pembatas yang ditentukan sebelumnya.

- Para pakar menyajikan pilihan mereka kepada anggota tim lainnya dan koordinator untuk dibahas.

- Setelah pembahasan akhir daftar K\&I untuk pengujian lapang disusun dan diatur di sepanjang baris yang disarankan di Bab 2.2.

- K\&I dalam daftar ini disediakan untuk anggota tim pakar berdasarkan disiplin ilmu dan beban kerja. Pengalaman menunjukkan bahwa seorang pakar dapat menangani maksimum sekitar $50 \mathrm{~K} \& \mathrm{I}$ selama tahap lapang.

- Para pakar memasukkan K\&I yang disediakan untuk mereka pada Formulir 2 (lihat Bab 3.3.4). 


\subsubsection{PERSIAPAN PENGUJIAN LAPANG}

Tahap pengujian lapang K\&I memerlukan perencanaan logistik, pertemuan dan penyaluran informasi yang disiapkan sebelumnya. Akomodasi dan transportasi harus disiapkan lebih dulu. Semua kelompok yang sesuai harus juga menerima informasi terbaru tentang tujuan kunjungan tim pakar, kebutuhan informasi dan bahan-bahan mereka serta jadwal kegiatan yang melibatkan pihak ketiga. Pemberitahuan sebelumnya kepada penyelenggara juga perlu dilakukan jika penerjemah dan staf pendukung lokal lainnya diperlukan. Jika UPH ada di lokasi terpencil, ketersediaan bahan-bahan tulisan yang memadai dan tempat kerja serta fasilitas yang perlu dipastikan.

\subsection{PENGUJIAN LAPANG K\&I: FILTER NO. 2}

\subsubsection{TUJUAN FILTER NO. 2}

Filter No. 2 adalah kegiatan evaluasi yang penting karena akan mengarah pada perampingan set K\&I. Para pakar mengeluarkan semua K\&I yang tidak diperlukan, memodifikasi yang masih ada untuk membuatnya lebih relevan dan mudah diterapkan, dan mengusulkan $K \& I$ baru untuk mengisi kesenjangan yang ditemukan selama kerja lapang.

\subsubsection{PROSES FILTERNO. 2}

Pada akhir Filter No. 1 anggota tim akan menerima tanggung jawab sesuai spesialisasi dan pengalamannya, masing-masing akan mendapat subset kriteria dan indikator yang akan dievaluasi secara lebih rinci.

Anggota tim pakar diharapkan akan melakukan sebagian besar kegiatan mereka secara berpasangan (bergantian) sehingga interaksi antardisiplin ilmu dapat dimaksimumkan. Kecuali untuk diskusi kelompok internal dan kasus 
tertentu, panel sebaiknya tidak melakukan kegiatan Filter No. 2 sebagai kelompok sendiri.

Proses Filter No. 2 terdiri dari langkah-langkah berikut:

Diskusi Awal Tim. Tujuannya adalah memperjelas metodologi pengujian bagi seluruh anggota tim. Jadwal kegiatan untuk tahap pengujian lapang juga diputuskan, setelah lokasi utama untuk evaluasi K\&I ditentukan. Penjadwalan akan ditetapkan sedemikian rupa sehingga anggota tim akan bekerja bersama dalam pasangan antardisiplin ilmu yang bergantian.

Kegiatan Lapang. Investigasi berikutnya akan dilakukan dengan cara yang fleksibel dan inovatif, yang akan meliputi, misalnya, penggunaan tim kecil berorientasi tugas antardisiplin ilmu. Tujuan kegiatan lapang adalah menguji tingkat penerapan kriteria dan indikator yang dipilih. Formulir 2 akan digunakan sebagai dasar untuk evaluasi ini, namun konsultan akan diajak untuk mengembangkan bahan-bahan metode evaluasi tambahan sesuai kebutuhan.

Agar dapat menguji kriteria dan indikator serta melaporkan hasil dalam Formulir 2, anggota panel pakar:

- melakukan diskusi kelompok dengan stakeholder/para pengguna hutan utama;

- wawancara individu dengan orang-orang penting (contoh: dengan para pembalak atau petani);

- melakukan survei lapang (contoh: lokasi pembalakan, kondisi jalan, perbatasan, regenerasi); dan

- melakukan studi pustaka jika memungkinkan. 
Untuk kepentingan berbagai investigasi ini, para pakar perlu diingatkan untuk membawa serta pustaka rujukan yang penting sesuai dengan spesialisasi mereka.

Diskusi Tim. Diskusi rutin tim dilakukan berselingan dengan kegiatan lapang, dan selama diskusi ini anggota tim diharapkan untuk: melaporkan kemajuan mereka dalam mengevaluasi K\&I, dan mendiskusikan serta mempertahankan perubahan atau tambahan yang mereka sarankan. Diskusi ini akan menjadi dasar untuk laporan yang akan disajikan oleh setiap pakar pada lokakarya penutup.

\subsubsection{PENGANTAR UNTUK FORMULIR 2}

Formulir 2 dirancang untuk mencatat penilaian-penilaian K\&I yang dipilih dilapang untuk evaluasi yang lebih intensif setelah Filter No. 1. Formulir ini juga dirancang untuk memberikan panduan cara melakukan evaluasi ini. Contoh Formulir 2 diberikan dalam Lampiran 8.2. Bacalah contoh ini waktu membaca langkah-langkah berikut.

- Setelah daftar kriteria dan indikator 'prioritas' disetujui (berdasarkan analisis dalam Formulir 1), setiap kriteria dan indikator ini akan dimasukkan pada Formulir 2 terpisah (dalam Kotak A).

- Setiap Formulir 2 akan diberikan kepada seorang anggota panel sesuai dengan bidang keahliannya.

- Anggota panel akan, mulai tahap ini, bertanggung jawab terhadap evaluasi set kriteria dan indikator yang ditugaskan kepada mereka. Mereka akan menggunakan Formulir 2 untuk mencatat observasi dan evaluasi mereka (hal. 1-3 dalam Contoh Formulir 2).

- Halaman 4 Formulir 2 disediakan terutama untuk evaluasi oleh anggota tim lainnya (Kotak J-O) dan Lokakarya (Kotak P). 
Dengan menggunakan Formulir 2, pengujian secara keseluruhan dipecah menjadi serangkaian tugas untuk tim pakar dan kelompok pendukung.

Selain menilai K\&I sesuai latar belakang dan pengalaman disiplin ilmunya, setiap pakar akan mengevaluasi semua K\&I 'prioritas' pada tahap ini dengan melibatkan semua disiplin ilmu. Tujuan penilaian ini adalah memaksimalkan interaksi di antara anggota-anggota tim dan untuk meningkatkan peluang untuk mendapatkan pandangan-pandangan baru yang akan dipadukan ke dalam proses penilaian.

\subsubsection{MENGGUNAKAN FORMULIR2}

Catatan-catatan berikut ini memberikan informasi yang diperlukan untuk mengisi Formulir 2:

Enam kotak tidak bernomor pertama pada Formulir 2 (Lampiran 8.2) berisi:

- nama anggota panel yang terutama bertanggung jawab untuk evaluasi kriteria dan indikator ('Inisial Pakar');

- dari mana asal set K\&I ('Sumber');

- nomor atau rujukan K\&I seperti dicatat dalam dokumen sumber (Identifikasi No. dalam sumber);

- subyek ('Kelompok'): P, S, M, E atau F;

- apakah setelah penyelesaian tahap lapang, K\&I direkomendasikan atau tidak ('Rekomendasi').

- nomor identifikasi akhir seperti didaftar dalam dokumen lokakarya ('No. Identifikasi Akhir'.).

Bagian A: Tuliskan kriteria dan indikator 'prioritas' seperti yang tercantum dalam dokumen sumber. Silakan merujuk pada formulir-formulir yang relevan mengenai semua anggota tim, sebelum menjalankan pemilihan ini. 
Bagian B: Berikan alasan Anda untuk pemilihan kriteria dan indikator yang terkait.

\section{Bagian C: Ciri-ciri}

Pandangan pakar tentang ciri-ciri berikut ini akan memberikan masukan utama untuk menentukan kegunaan K\&I tertentu. Masing-masing ciri ini akan diurutkan pada skala 1 sampai 5 di mana 1 berarti tidak, buruk atau tidak penting; dan 5 berarti ya, baik atau penting.

Perhatikan bahwa dua kotak masukan telah disediakan untuk setiap ciri dalam bagian formulir ini (dan untuk bagian pertanyaan dalam bagian-bagian berikutnya). Kotak pertama (d) mengacu pada kriteria atau indikator seperti yang tercantum dalam Bagian A, yang merupakan pilihan awal. Jika pilihan K\&I awal kemudian dimodifikasi, K\&I ini akan dicatat dalam Bagian F. Versi akhir ini kemudian harus dievaluasi dan diperbarui sesuai dengan yang tercatat dalam kotak (o). Dengan membandingkan evaluasi (d) dan (o) pembaca akan menilai perbedaan di antara versi awal dan versi yang direvisi.

Ciri-ciri yang akan diberi skor dalam Bagian $\mathrm{C}$ adalah:

- Apakah memberikan ringkasan atau pengukuran yang terintegrasi? Apakah meringkas atau mengintegrasi banyak informasi? Apakah informasinya efisien?

- Apakah kaitannya erat dan berhubungan dengan tujuan penilaian?

- Apakah responnya memadai terhadap perubahan tingkat tekanan? Apakah sensitif terhadap perubahan pada lingkungan atau pada sistem? Apakah memberikan informasi yang berarti tentang perubahan ini?

- Apakah secara diagnostis spesifik? Apakah indikator (atau kriteria) memberi tahu kita bagaimana hubungan kriteria yang bersangkutan? atau 
apakah lebih umum, mungkin berhubungan dengan lebih dari satu kriteria atau wilayah? Skor yang tinggi di sini berarti persoalan tersebut spesifik secara diagnosis.

- Apakah menarik untuk para pengguna? Dapatkah para calon pengguna merasa tertarik menggunakannya? Apakah hemat biaya?

- Apakah mudah dideteksi, diukur, dicatat dan ditafsirkan? Seberapa layak kriteria/indikatornya?

- Dapatkah secara persis didefinisikan? Apakah artinya jelas? Dapatkah dua orang yang berbeda mengertinya dengan cara yang sama? (Coba ujikan dengan anggota panel kawan Anda)

- Apakah hasilnya dapat diperbanyak? Apakah dapat dipercaya dan dapat diulang? Seberapa kokoh perkiraan yang didasarkan pada indikator atau kriteria?

- Sejauh mana relevansi kriteria dan indikator ini? Pendapat Anda tentang relevansi kriteria atau indikator ini terhadap kelestarian.

- Ciri-ciri lain: Misalnya, apakah pengukuran absolut atau relatif yang lebih baik?

Bagian D: Berikan rujukan pustaka untuk memberikan bobot tambahan terhadap keputusan, jika mungkin.

Bagian E: Berikan rujukan kriteria dan indikator yang sama dari set K\&I lainnya.

Bagian F: Jika kriteria dan indikator yang dipilih di Bagian A mengalami perubahan definisinya, versi terakhirnya harus dicatat di sini. Diasumsikan bahwa keputusan untuk perubahan ini telah dicatat pada hal. 2 dan 3.

Bagian G: Cantumkan catatan-catatan tambahan dalam ruang ini. Jika kriteria dan indikator ditolak, berikan alasannya di sini. 
Bagian H: Jika K\&I ini kemudian digunakan dalam penilaian aktual untuk pengelolaan hutan, apakah penilaian ini perlu dilakukan di lapang, atau dapatkah dilakukan di kantor, atau apakah keduanya perlu?

Bagian I: Jenis dokumen apa (atau cara-cara verifikasi, seperti: inspeksi lapang) yang diperlukan oleh penilai dalam rangka mengevaluasi pengelolaan hutan menggunakan K\&I ini?

Bagian J: Catatan harian kegiatan-kegiatan pokok yang dilakukan untuk mengevaluasi kriteria dan indikator ini disimpan dan dicatat di sini. Catatan harian ini akan membantu memberikan alasan-alasan untuk pemilihan, modifikasi atau penolakan pada waktu lokakarya dan selama tahap analisis lanjutan. Jika perlu jumlah halamannya bisa ditambah.

Bagian K: Pada bagian ini pemimpin tugas yang bertanggung jawab akan menentukan apakah kriteria dan indikator termasuk dalam ketegori 'masukan dari manusia' (contoh: modal, tenaga kerja) atau 'proses oleh manusia' (sebagai kebalikan proses alami) seperti berbagai proses perencanaan atau apakah sebagai 'hasil/keluaran' dari kedua kategori pertama dalam sistem biofisik atau sosial.

Masukan dari manusia dan proses oleh manusia sering sangat berbeda. Suatu indikator seperti 'Rencana karya tahunan, lima tahunan dan dua puluh tahunan ada' dapat merupakan masukan yang merupakan hasil proses 'Pengelolaan didasarkan pada kerangka perencanaan yang tepat...'. Masukan umumnya lebih mudah dicatat, diperkirakan dan ditafsirkan. Di lain pihak, proses sering lebih menunjukkan komitmen pengelolaan untuk mencapai tujuannya. 
Bagian L: Bagian ini memberikan klasifikasi kriteria dan indikator berdasarkan apakah mereka mengacu pada 'tekanan' terhadap sistem (biofisik, sosial atau pengelolaan), menguraikan 'keadaan' atau menguraikan cara-cara sistem 'menanggapi' tekanan. Klasifikasi ini memberikan cara yang efektif untuk melihat berbagai sebab dan akibat. Menentukan apakah kriteria atau indikator cukup menampung informasi tentang sumber tekanan utama, dan tanggapan sistem terhadapnya, adalah faktor utama dalam memutuskan secara obyektif keefektifan dan tingkat kepercayaan kriteria dan indikator tersebut secara keseluruhan.

Bagian M: Bagian ini mencatat berbagai kemungkinan hubungan dengan aspek lain, seperti antara K\&I ekologis dan sosial. Bagian A sampai L telah mencoba menguji apakah untaian yang benar telah dirangkaikan ke dalam rangkaian ini, dan apakah lubang jaringnya berukuran tepat untuk menangkap informasi yang kita perlukan. Dalam Bagian M yang kita cari adalah kaitan antara kriteria dan indikator, untuk memastikan agar informasi yang sama dan sejenis tidak dikumpulkan dua kali dan untuk memastikan apakah ada putaran umpan balik antara kriteria dan indikator. Contoh putaran umpan balik yang penting dalam kehutanan, misalnya, antara regenerasi dan pertumbuhan pada satu sisi dan cara-cara silvikultur dan siklus penebangan di sisi lainnya. Sistem kriteria dan indikator yang efektif perlu mencerminkan putaran informasi ini.

Bagian N: Bagian catatan lokakarya akan digunakan oleh setiap anggota tim untuk mencatat kesimpulan yang terpenting dari lokakarya kriteria atau indikator. 


\subsubsection{BEBERAPA METODE LAPANG YANGBERGUNA}

\section{Strukturisasi Interaksi Tim}

Kerjasama antardisiplin ilmu tidak terjasi secara otomatis. Dalam rangkaian pengujian K\&I CIFOR, empat teknik berikut digunakan untuk mengembangkan kerjasama yang efektif di antara anggota tim.

- Pelatihan secara eksplisit. Pelatihan seperti ini dapat meliputi presentasi dengan fokus pentingnya kerjasama antardisiplin ilmu, kekuatan yang berbeda yang dapat diberikan oleh disiplin ilmu yang berbeda, dan halhal praktis tentang apa yang sebaiknya dilakukan dan jangan lakukan, yang perlu selalu diingat oleh anggota tim (lihat di bawah 'Mengembangkan Komunikasi Antardisiplin Ilmu').

- Memasangkan disiplin ilmu yang berbeda. Walaupun keberhasilan dalam usaha ini akan berbeda dari waktu ke waktu dan dari satu tim ke tim lain, langkah ini perlu sekali diusahakan agar anggota tim menggilir rekan kerjanya sehari-hari di antara disiplin ilmu yang berbeda. Penggiliran ini memungkinkan anggota tim untuk mendapatkan wawasan yang lebih luas tentang ide-ide dan persepsi, yang potensial dan bermanfaat, dari anggota tim lainnya.

- Teladan kepemimpinan. Koordinator dan tim pendukung harus menciptakan kerjasama dan komunikasi antardisiplin ilmu yang cukup baik antara mereka sendiri. Anggota tim yang secara teratur melihat dan mengalaminya pasti akan mengikuti teladan ini. Untuk itu diperlukan saling mendukung satu sama lain, dan pemahaman yang tepat terhadap kekuatan yang berbeda dari disiplin ilmu masing-masing.

- Kebersamaan. Tim sebaiknya tetap bersama setiap hari. Dalam semua pengujian CIFOR mereka tinggal di kamp yang sama, makan makanan yang sama dan mengamati unit pengelolaan hutan yang sama, selama 
periode satu bulan. Kebersamaan dan keterbukaan terus-menerus seperti ini, dalam konteks mendorong komunikasi antardisiplin ilmu, juga berfungsi mendorong kerjasama dan saling berbagi perspektif/pandangan.

Anggota tim perlu sering bertemu dalam kelompok untuk mendiskusikan kemajuan dalam mengevaluasi K\&I. Selama pengujian CIFOR, pertemuan ini diadakan setiap 3-4 hari. Pertemuan ini umumnya berlangsung setengah hari bila topik diskusi sangat luas. Pertemuan-pertemuan pada awal proses pengujian sering lebih banyak membahas konsep-konsep prinsip, kriteria, indikator dan pengukur daripada evaluasi K\&I, yang merupakan diskusi yang mendominasi pertemuan selanjutnya. Kebanyakan pertemuan tim mengungkap konflik-konflik pendekatan koseptual dalam mengevaluasi K\&I, terutama di antara ilmuwan sosial dan biofisik. Pemimpin dalam pertemuan ini perlu memandu pertemuan sehingga hambatan-hambatan dapat dihindari, tetapi tidak keluar dari proses. Selama pengujian CIFOR pertemuan tim ini merupakan sarana yang sangat bermanfaat untuk memperbaiki K\&I. Untuk itu pertemuan ini besar potensi manfaatnya, tetapi harus digunakan sebagaimana mestinya. Jika tidak, konflik antarindividu akan menimbulkan tekanan yang tidak perlu.

\section{Mengembangkan Komunikasi Antardisiplin Ilmu}

Komunikasi antardisiplin ilmu yang efektif tentu penting sekali supaya metode pengujian K\&I dapat berjalan. Kami menemukan empat sikap yang penting dalam mengembangkan komunikasi:

- kemauan berkompromi yang beralasan untuk mengakomodasi kebutuhan anggota tim yang lain;

- minat yang tulus untuk mempelajari bidang lain;

- respek yang sungguh-sungguh terhadap anggota tim lain dan mengakui 
relevansi bidang keilmuan mereka; dan

- kesepakatan yang cukup tinggi di antara anggota tim mengenai sasaran yang ingin dicapai.

Di samping itu, kami mengembangkan daftar pendek tentang apa yang boleh 'dilakukan' dan yang 'tidak boleh dilakukan' yang kami temukan sangat berguna.

Lakukan:

- Identifikasi kekuatan rekan kerja Anda. Konsentrasikan pada apa yang mereka dapat lakukan, bukan apa yang tidak dapat mereka lakukan.

- Jika Anda tidak memahami sesuatu, asumsikan karena ketidaktahuan Anda, dan bukan karena kebodohan rekan Anda. (Misalnya, disiplin ilmu yang berbeda mungkin menggunakan istilah yang sama tetapi maksudnya berbeda, atau memiliki cara berpikir yang berbeda untuk memikirkan suatu persoalan).

- Kalau mengkritik lakukanlah dengan cara yang halus, sopan dan konstruktif, sehingga anggota tim akan merasa tenang mengungkapkan ketidaktahuan mereka dan untuk dikoreksi.

- Bagikan penemuan dan pendekatan dengan terbuka dan bermurah hatilah memberikan kredit kepada rekan kerja Anda untuk kontribusi mereka.

- Bersabarlah dan, jika perlu, mengalah, terutama dalam situasi di lapang, di mana orang mungkin mengalami stres yang tidak normal.

Jangan Lakukan:

- Membuat penilaian yang merendahkan tentang paradigma lain dalam melakukan penelitian. Berbagai konsep yang berbeda diperlukan dalam konteks ini. 
- Bersaing dengan anggota tim lain. Hal ini selalu akan sangat tidak produktif dan membuang waktu yang berharga.

\section{Pengumpulan Data dan Evaluasi K\&I}

Evaluasi lapang K\&I tidak selalu berarti mengumpulkan banyak data primer. Namun selama rangkaian pengujian K\&I CIFOR kebanyakan pakar mengumpulkan data primer dan sekunder untuk memperjelas pemikiran mereka tentang K\&I tertentu. Karena disiplin ilmu yang terlibat sangat berbeda, tipe data yang dikumpulkan juga sangat berbeda, sehingga sulit untuk memberikan cara yang mudah dan cepat untuk mengumpulkan data.

Selain wawancara, kuesioner dan diskusi, perangkat yang digunakan oleh para pakar selama rangkaian pengujian CIFOR memberikan cara-cara tambahan dalam mengevaluasi $K \& I$ yang mencakup:

- survei fisik kerusakan yang disebabkan oleh pemanenan kayu (contoh: erosi, jalan sarad, ukuran rimpang, penyeberangan sungai, pembuatan bendungan);

- pengumpulan data sekunder di kamp kerja kantor pengelola, kantor pemerintah lokal, rumah sakit lokal, dll.;

- survei regenerasi di rimpang-rimpang yang besar, tempat pendaratan kayu, rimpang-rimpang tebangan, hutan primer, hutan sekunder, dll.;

- survei jaringan jalan, batas-batas petak kerja, kawasan rehabilitasi silvikultur, petak-petak tanam, dll.;

- inspeksi mendadak untuk kepatuhan terhadap rencana pengelolaan, panduan pengelolaan, dll.; dan

- survei transek atau lereng ekologis, pengambilan sampel di plot sampel permanen, dll. 
Pada prinsipnya, metode survei apa saja yang membantu untuk pakar menyimpulkan tentang kualitas dan K\&I tertentu dibolehkan. Penjelasan tambahan tentang metode yang digunakan untuk menentukan nilai K\&I tertentu sebaiknya didokumentasikan dalam Formulir 2 untuk rujukan yang akan datang.

\section{Mengidentifikasi Stakeholder dan Para Pengelola Hutan}

Stakeholder adalah pihak-pihak yang memiliki minat atau kepentingan terhadap hutan. ${ }^{7}$ Mengharapkan perusahaan $\mathrm{HPH}$ untuk memperhatikan semua kepentingan masyarakat (dari konsumen lokal sampai internasional) jelas tidak realistis. Isu ini tidak dijelaskan secara mendalam di dalam set K\&I yang ada.

Untuk itu kami mengembangkan metode sederhana untuk memisahkan 'para pengelola hutan' yang paling penting dari kategori stakeholder atau individu yang lebih luas yang berkepentingan dengan hutan. ${ }^{8}$ Tim CIFOR mengidentifikasi stakeholder secara kualitatif dan ternyata proses ini cukup mudah. Suatu daftar stakeholder mencakup warga negara, konsumen, pegawai Departemen Kehutanan, wiraswastawan skala kecil dan para pekerja hutan. Dalam setiap lokasi pengujian kami, kelompok-kelompok yang spesifik di lokasi tersebut juga kami identifikasi. Misalnya, di HPH Kiani Lestari di Kalimantan Timur, kami mengidentifikasi kelompok Dayak, Kutai (dua kelompok indijenus) dan para transmigran (migran yang datang dari pulau-pulau lain) sebagai stakeholder tambahan. Dalam contoh di Pantai Gading, kami

7 Bahan yang disajikan di sini diberikan dalam Colfer (1995) secara lebih lengkap.

8 Untuk keperluan dalam dokumen, 'para pengelola hutan' adalah bagian dari 'stakeholder' yang paling penting untuk pengelolaan hutan. 
mengidentifikasi Agni (Autochtones, atau kelompok etnis indijenus), Allochtones (masyarakat asli dari daerah lain di Pantai Gading) dan Allogens (khususnya pengungsi dari negara lain). Untuk informasi lebih lanjut mengenai metode ini, silakan mengacu ke Perangkat No. 5-8.

Setelah mengidentifikasi stakeholder, anggota tim menilai setiap kelompok stakeholder dengan memberikan skor sederhana 1 (tinggi) sampai 3 (rendah), untuk enam dimensi berikut.

- Kedekatan dengan Hutan. Masyarakat yang tinggal di dalam atau di sekitar hutan memiliki kesempatan yang lebih besar terkena dampak pengelolaan hutan atau mempengaruhi pengelolaan hutan. Arti kedekatan ini secara lebih pasti bervariasi dari satu tempat ke tempat lainnya, bergantung pada kualitas transportasi dan infrastruktur.

- Hak Masyarakat Lokal. Di banyak kawasan hutan yang dikelola untuk kepentingan komersial mungkin ada konflik paradigma tentang arti kepemilikan dan penggunaan lahan. Kadang masyarakat yang telah melakukan kegiatan dalam kawasan tertentu selama beberapa dekade, abad bahkan milenium, akhir-akhir ini hak tradisional mereka telah direbut atau sangat ditekan. Dari segi pragmatis dan sudut pandang keadilan, klaim masyarakat ini perlu dihormati.

- Ketergantungan. Stakeholder tertentu mengandalkan kebutuhan hutan karena hidupnya dari hutan. Masyarakat mungkin berburu, menangkap ikan, mengumpulkan makanan, obat dan serat, atau melakukan agroforestri. Sumber daya yang menjadi dasar sistem ekonomi mikro masyarakat memiliki implikasi yang penting bagi kesejahteraan masyarakat, dan juga bagi hutan.

- Pengetahuan Lokal. Masyarakat yang telah lama tinggal di kawasan hutan sering memiliki pengetahuan unik dan berguna, karena pengalaman lokal 
jangka panjang mereka. Pengetahuan ini dapat dimanfaatkan untuk meningkatkan pengelolaan hutan menjamin suara mereka di masa depan.

- Integrasi Hutan/Budaya. Budaya atau cara hidup - termasuk budaya masyarakat hutan - cenderung erat sekali hubungannya dengan lingkungan mereka. Mungkin ada tempat-tempat keramat di dalam hutan, sistem simbol yang memberi arti bagi kehidupan mereka dan sangat erat dengan perasaan masyarakat tentang diri mereka, tumbuhan hutan merupakan cadangan pengamanan selama musim paceklik, dan banyak sekali hubungan lainnya.

- Defisit Kekuasaan. Penduduk yang tinggal di dalam atau di dekat hutan sering lebih lemah dibandingkan dengan stakeholder lain. Di mana defisit kekuasaan lokal terjadi, pengaruhnya mungkin merugikan bagi hutan, karena penduduk tidak mempunyai cara-cara untuk melindungi sumber daya mereka dari tekanan luar.

Setelah masing-masing stakeholder dinilai berdasarkan setiap dimensi tersebut, skornya dapat dirata-ratakan, sehingga setiap stakeholder mendapatkan skor tunggal. Kami menyimpulkan bahwa stakeholder yang mendapat skor 2 atau kurang adalah mereka yang membutuhkan perhatian khusus dalam pengelolaan hutan secara komersial. Stakeholder tersebut diidentifikasi sebagai 'pengelola hutan'.

\section{Panduan Wawancara Dasar}

Wawancara merupakan dasar sebagian besar data yang dikumpulkan oleh tim yang menilai K\&I. Oleh karena itu, ilmuwan sosial dalam tim memiliki tanggung jawab khusus untuk membantu anggota tim lain dalam hal ketrampilan mewawancarai. Karena tim beroperasi sebagai satu unit, ada kemungkinan kekurangmampuan mewawancarai oleh satu orang berpengaruh merugikan bagi pekerjaan yang lain. 
Berikut ini adalah beberapa panduan, yang perlu diperhatikan oleh ilmuwan sosial dalam tim.

- Bangunlah hubungan dengan responden dengan menjelaskan mengapa Anda di sana dan apa yang Anda inginkan dari responden.

- Sensitiflah dengan suasana wawancara. Informasi yang berbeda akan muncul tergantung faktor-faktor ini, seperti pemilihan waktu dan lokasi, dan apakah wawancara dengan individu atau kelompok, jenis kelamin/ kelompok etnis/umur yang sama atau campuran, dll.

- Cobalah mendapatkan responden dalam spektrum yang luas (status dan kesejahteraan tinggi atau rendah, kelompok etnis, umur, kegiatan, jender/ jenis kelamin berbeda).

- Tunjukkan rasa hormat Anda terhadap mereka dan pendapat mereka (mungkin dengan cara duduk bersama di lantai, memakan makanan mereka, mengikuti arah pembicaraan mereka terus-menerus). Masyarakat lebih menerima jika mereka merasakan rasa hormat dan apresiasi Anda.

- Tanyakan pertanyaan terbuka sebagai cara agar tidak mengarah pada pandangan pribadi Anda. Hindari ‘pertanyaan yang mengarah' (yaitu, pertanyaan yang jawaban atau pendapatnya jelas mengarah pada keinginan pewawancara). Hindari pertanyaan dengan jawaban 'ya-tidak'. Sebaliknya mintalah masyarakat menceritakan apa yang terjadi, atau untuk memberitahukan sesuatu.

- Wawancara umumnya memerlukan responden untuk mengingat peristiwa dan persepsi. Gunakan peristiwa seperti kekeringan, pemilihan umum, ulang tahun anak, dll. Untuk memancing ingatan dan kejadian tertentu. Jika Anda memerlukan informasi sejarah, biasanya lebih mudah memulainya dengan waktu sekarang dan kemudian mundur. Anda dapat menggunakan triangulasi untuk memeriksa persepsi. 
- Jaga kerahasiaan apa yang mereka ceritakan kepada Anda (dengan menyembunyikan bahan sensitif, menggunakan nama samaran, mengubah detail yang tidak relevan untuk menjaga individu atau masyarakat, jika diperlukan).

- Jawablah pertanyaan mereka kepada Anda. Tunjukkan kepercayaan Anda terhadap masukan mereka dengan jelas dan berterimakasihlah kepada mereka untuk bantuannya yang bermanfaat.

\subsubsection{PERLUNYA MENGGABUNGKAN PENDEKATAN TOP_ DOWN DAN BOTTOM-UP}

Selama kegiatan lapang, kepentingan sumber informasi yang top-down maupun bottom-up perlu ditekankan. Kegunaan konsep kerangka kerja (lihat Bab 5) adalah untuk memudahkan pengembangan sistem untuk menilai pengelolaan hutan lestari. Satu pertanyaan penting adalah di mana memulai pengembangan ini: di bagian atas atau bawah? Jawabannya adalah keduanya.

Proyek CIFOR berpendapat bahwa sistem penilaian kelestarian harus dirumuskan dari yang top-down. Contohnya, prinsip perlu didefinisikan lebih dulu sebelum beralih pada tingkat kriteria dan indikator. Prinsip-prinsip didefinisikan berdasarkan kebijaksanaan dan pengetahuan. Ini untuk menjamin bahwa ada fokus yang benar untuk penilaian sistem. Dalam bidang yang berhubungan dari penilaian risiko ekologis, Gentile dan Slimak (1992) juga menyarankan bahwa pendekatannya sebaiknya top-down. Langkah pertama menurut mereka adalah mendefinisikan target bernilai ekologis tertinggi dan kemudian bergerak menurun mengidentifikasi sederetan titik terakhir dan indikator ekologis yang sesuai. Cara kerja seperti ini memiliki 
nilai tambah karena nilainya terintegrasi dengan titik terakhir dan indikator ekologis yang terpilih.

Tim CIFOR yang terlibat dalam beberapa rangkaian pengujian mengikuti proses yang sama ini. Pendekatan CIFOR menggunakan pengalaman dan pertimbangan para pakar, bersama dengan konsep kerangka kerja yang diuraikan dalam Bab 5, untuk menggarap serangkaian isu intelektual dan isu-isu kritis untuk topik yang diteliti. Dalam proses top-down penggunaan kerangka kerja yang ada untuk pengelolaan hutan lestari juga sangat membantu (contoh: prinsip dan panduan kriteria dan indikator FSC, ITTO) sebagai dasar untuk pengembangannya.

Namun, setelah sampai pada prinsip dan kriteria dasar dalam model ini, proses selanjutnya perlu dibalik, dan mengutarakan pertanyaan yang sama dari yang bottom-up.

Prinsipnya, para pakar CIFOR pertama memulai memikirkan penerapan $\mathrm{K} \& \mathrm{I}$

Sasaran proses bottom-up adalah untuk memastikan bahwa informasi dari lapang tidak hilang; sasaran proses top-down adalah untuk memastikan bahwa informasi konseptual yang benar tetap dipakai. bottom-up waktu mereka mempertimbangkan 1.100 kriteria dan indikator dalam lima set awal K\&I yang tersedia. Walaupun tahap pertama (Filter No. 1) tidak melibatkan kerja lapang, para pakar mengambil pengalaman lapang sebelumnya di lokasi yang tepat atau serupa untuk memulai proses bottom-up.

Pada tahap ini $1.100 \mathrm{~K} \& \mathrm{I}$ dapat dipertimbangkan secara sederhana sebagai kemungkinan elemen-elemen dalam sebuah 'kotak perangkat' penilaian kelestarian. Elemen-elemen ini sebelumnya telah menjalani pra-penyaringan 
berdasarkan pengalaman sebelumnya yang dimiliki para pakar, dan elemen yang diperkirakan paling berguna ditempatkan ke dalam kerangka kerja logis yaitu prinsip, kriteria dan indikator.

Pada tahap selanjutnya, data dan informasi dari lokasi lapang ditambahkan. Data ini kemudian menjadi dasar untuk analisis bottom-up menurut tingkat/ level kriteria dan prinsip yang dikerjakan. Set minimum K\&I yang sesuai kemudian diidentifikasi melalui pembandingan proses top-down dan bottomup dalam pemikiran tim pakar. Mengin-Lecreulx dkk. (1995) telah menggambarkan proses ini sama seperti yang diperlihatkan dalam Gambar 3 . Proses ini digunakan tidak hanya oleh tim lapang, tetapi juga dalam mengekspresikan kerangka kerja konseptual untuk kelestarian sosial (Colfer dkk. 1995).

Perlu dipahami bahwa pendekatan top-down dan bottom-up harus diintegrasikan ke dalam proses pengulangan secara berputar untuk memperbaiki kriteria, indikator dan pengukur. Integrasi ini penting karena pemahaman kita tentang proses-proses yang mendorong interaksi antara manusia dan ekosistem tidak lengkap. Dengan semakin berkembangnya pemahaman, standar dan praktek pengelolaan berkembang juga. Informasi baru ini perlu dimasukkan dalam proses pendefinisian perangkat penilaian kelestarian. Perlu diakui bahwa informasi baru ini bukan saja hasil usaha saat ini, tetapi sering merupakan masukan informasi yang sebelumnya diabaikan atau dianggap kurang bernilai, seperti pengetahuan tradisional penduduk lokal. Karena itu, di samping pengulangan menurut skala waktu, perlu juga untuk mengulang proses ini menurut ruang dan untuk mengumpulkan sampel ekosistem hutan yang sangat beragam, masyarakat dan kebutuhan mereka terhadap hutan. 
Proses yang diuraikan di atas sangat penting bagi anggota tim pakar untuk mengevaluasi, mengembangkan dan menghasilkan kriteria dan indikator.

\section{Gambar 3. Gambaran skematis proses 'top-down' dan 'bottom-up' untuk evaluasi K\&I.}

'Lingkaran bergaris putus-putus' menggambarkan uraian isu-isu kritis yang terwujud sebagai prinsip dan kriteria. Bulatan hitam menggambarkan K\&I dalam set dasar. Nomor 1

menggambarkan kesenjangan dalam set dasar (K\&I yang diusulkan); nomor 2 menggambarkan keseimbangan antara K\&I dalam set dasar dan konsep kerangka kerja - K/I yang dipilih; nomor 3 menggambarkan kesenjangan dalam kerangka kerja konsep pakar; dan nomor 4 menggambarkan $K \& I$ di luar batas kerangka kerja konsep - K/I yang ditolak.

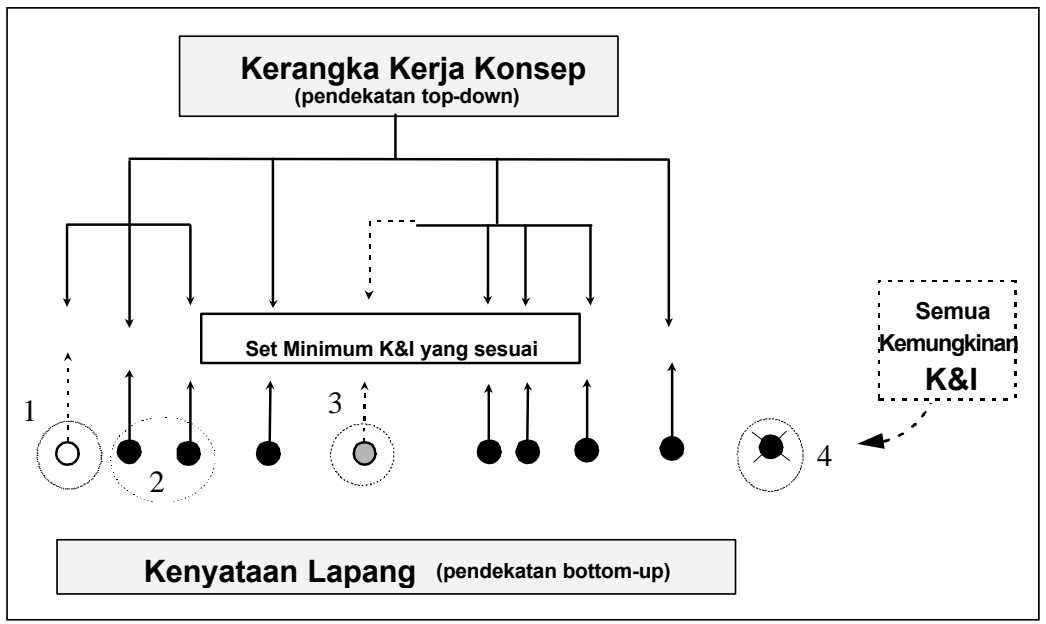

\subsubsection{PERSIAPAN LOKAKARYA}

\section{Tabulasi/Penyusunan Analisis Hasil}

Pada akhir tahap pekerjaan lapang, hasil-hasilnya perlu ditabulasi dalam format yang mudah dimengerti oleh peserta lokakarya berikutnya. Informasi 
yang terpenting yang terkandung dalam tabel ini adalah set K\&I minimum yang bisa dipercaya. Hasil ini perlu disusun sedemikian rupa sehingga sasaran penilaiannya selalu jelas. Hasil ini dikelompokkan secara menurun dari prinsip sampai ke pengukur. Dalam Lampiran 8.4 kami memberikan contoh cara penyajian K\&I dalam lokakarya selama rangkaian pengujian oleh CIFOR.

\section{Laporan Singkat oleh Tiap Pakar}

Untuk menyiapkan lokakarya akhir, anggota tim pakar sebaiknya menyiapkan laporan singkat tentang cara mereka mengevaluasi kriteria dan indikator. Seperti disebutkan di atas, ada perbedaan pendekatan di antara para pakar, sesuai latar belakang disiplin ilmu, pengalaman dan pendapat pribadi masingmasing. Namun, peserta lokakarya mengerti dengan jelas proses evaluasi yang digunakan dalam setiap kasus. Masukan untuk laporan ini sebagian besar bisa berdasarkan catatan yang dikumpulkan dalam Formulir 2 .

Judul-judul berikut disarankan untuk laporan ini:

- set K\&I dasar: evaluasi kontribusi mereka terhadap hasil akhir;

- berbagai metode yang digunakan untuk mengevaluasi K\&I, termasuk teknik pengumpulan data; dan

- usulan-usulan untuk set akhir K\&I, termasuk penyusunan K\&I, dan juga penetapan peringkat dan metode-metodenya, jika memungkinkan.

\subsection{LOKAKARYA: FILTER NO. 3}

\subsubsection{TUJUAN LOKAKARYA}

Kecuali analisis lanjutan dan penulisan laporan, lokakarya akhir adalah langkah terakhir dalam prosedur pengujian K\&I. Keluaran terpenting dari lokakarya adalah set kriteria dan indikator yang jelas definisinya. Lokakarya 
ini dapat dijadikan sarana untuk saling melakukan pengkajian hasil kerja anggota tim. Karena kerangka rujukan peserta lokakarya biasanya lebih luas daripada UPH yang dipilih, lokakarya juga bisa merupakan tinjauan pertama K\&I yang diusulkan oleh tim, yang dapat diterapkan lebih luas. Sebagai bagian lokakarya, anggota tim meringkas pengalaman mereka dan menyimpulkan dalam laporan, menampung rekomendasi dari lokakarya. Hasil ini kemudian disampaikan kepada koordinator pengujian, untuk dinilai dan dievaluasi, secara kualitatif maupun kuantitatif. K\&I yang berkembang diharapkan dapat digunakan oleh penilai (contoh: pemerintah nasional, donor, lembaga sertifikasi).

Dalam lokakarya ini pusatkan perhatian pada diskusi tentang kriteria dan indikator. Hindarilah diskusi yang tidak jelas tentang kelestarian, sertifikasi atau isu-isu sejenis. Keluaran lokakarya harus berupa set kriteria dan indikator yang definisinya jelas. Pada akhir lokakarya fokusnya adalah:

- berbagai metode lapang yang digunakan untuk pengujian K\&I;

- kegunaan kriteria dan indikator yang direkomendasikan sebagai perangkat evaluasi;

- kehematan biaya dari kriteria dan indikator yang direkomendasikan;

- alasan-alasan pemilihan set kriteria dan indikator yang direkomendasikan (perhatikan bahwa setiap anggota tim diharapkan untuk memberikan alasan mereka dalam memilih keputusan kriteria dan indikator); dan

- kepentingan relatif (faktor bobot) kriteria dan indikator yang dipilih.

\subsubsection{AGENDA, STRUKTUR DAN PENGATURAN LOKAKARYA}

Peserta lokakarya akhir juga melibatkan peserta tambahan yang harus didatangkan dari berbagai lembaga dan latar belakang disiplin ilmu. Semua sebaiknya memiliki pengetahuan dan kepentingan terhadap pengelolaan hutan lestari. Lokakarya berlangsung selama tiga sampai lima hari. 
Jika mungkin, undanglah masyarakat lokal sebagai peserta lokakarya. Namun, dalam banyak kasus, diperlukan upaya keras untuk mendatangkan mereka dan memberikan latar belakang yang tepat sehingga mereka dapat berpartisipasi secara penuh. Yang lebih penting, peserta lokal memberikan kontribusi nyata dalam lokakarya dan tidak begitu saja dipilih sebagai perwakilan.

Lokakarya umumnya diatur berupa diskusi-diskusi oleh kelompok kerja yang diberi tugas untuk mengkaji usulan-usulan yang dibuat oleh tim yang terkait. Sebagian besar diskusi diadakan di dalam kelompok kerja kecil ini mengenai subyek spesifik yang ditentukan. Setiap kelompok kerja akan dipandu oleh ketua dan akan dibantu seorang penulis untuk mencatat temuan-temuan yang terpenting. Pokok bahasan awal untuk diskusi di dalam masing-masing kelompok biasanya adalah hasil dari Filter No. 2 dan proses yang digunakan dalam mengidentifikasi K\&I untuk bidang yang diteliti. Formulir 2 merupakan dokumen acuan utama untuk diskusi ini.

Setiap kelompok kerja akan menyiapkan laporan yang kemudian disajikan dalam sesi pleno. Agenda dan jadwal lokakarya yang biasa dilakukan disajikan dalam Tabel 4.

\subsubsection{SESI PLENO}

Sesi pleno lokakarya menyediakan forum diskusi yang berkaitan dengan isuisu umum yang dihadapi seluruh kelompok kerja dan memberikan pengantar untuk keseluruhan proses K\&I bagi yang bukan anggota tim. Tujuan sesi pleno adalah untuk:

- memperkenalkan dan menjelaskan sasaran pengujian K\&I bagi peserta yang bukan anggota tim; 
- menjelaskan kerangka rujukan untuk pengujian (contoh: suatu UPH di lokasi tertentu sebagai fokus);

- memperkenalkan lokasi-lokasi di mana pengujian dilakukan;

- memperkenalkan berbagai metode yang digunakan kepada peserta yang bukan anggota tim;

- menjelaskan isu-isu penting (termasuk yang diangkat oleh peserta) sebelum sesi kelompok kerja dimulai.

\section{Tabel 4. Agenda yang disarankan untuk lokakarya akhir.}

\section{HARI 1}

08:00-08:30 Pendaftaran peserta

08:30-09:30 Pidato Pembukaan, pengantar

09:30-10:00 Rehat

10:00-11:00 Tinjauan pengujian awal K\&I

11:00-12:00 Presentasi penggunaan kriteria dan indikator, terutama untuk kepentingan sertifikasi, diikuti diskusi

12:00-13:30 Makan siang

13:30-15:30 Laporan tim

Berbagai metode dan proses yang digunakan untuk pengujian kriteria $\&$ indikator

Pengujian pengelolaan untuk produksi kayu

Pengujian kriteria \& indikator ekologis

Pengujian kriteria \& indikator sosial

Pengujian kriteria yang berkaitan dengan pelestarian produksi barang dan jasa nonkayu

15:30-16:00 Rehat

Kerangka kerja konseptual untuk sistem evaluasi

16:00-17:30 Laporan Diskusi Tim

17:30 Penutup

\section{HARI 2}

08:30-09:00 Presentasi sebuah topik umum

09:00-10:00 Pengantar untuk kelompok kerja dan berbagai metode (pleno) 


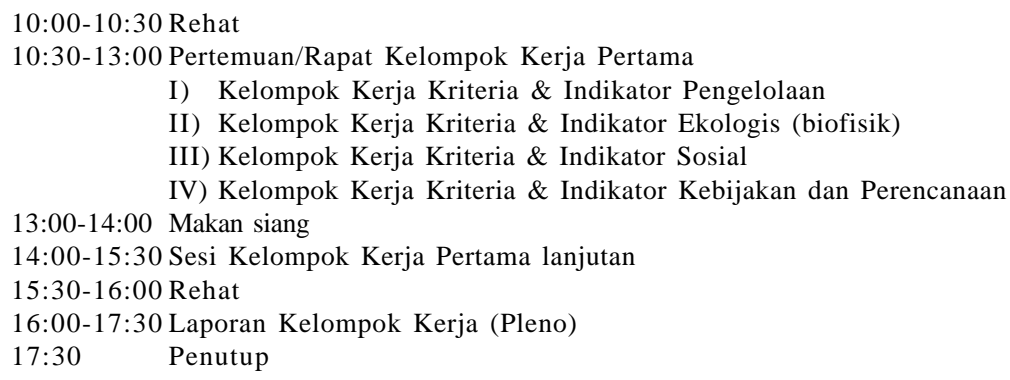

\section{HARI 3}

08:30-09:30 Presentasi sebuah topik umum 09:00-10:00 Pleno untuk mengkaji kemajuan 10:00-10:30 Rehat

10:30-12:30 Pertemuan/Rapat Kelompok Kerja Kedua

I) Lanjutan Kelompok Kerja

II) Lanjutan Kelompok Kerja

III) Lanjutan Kelompok Kerja

IV) Lanjutan Kelompok Kerja

12:30-13:30 Makan siang

13:30-15:00 Laporan Sesi Kelompok Kerja Kedua (pleno)

15:00-15:30 Rehat

15:30-17:00 Sesi Penutupan (Pleno)

\subsubsection{SESI KELOMPOK KERJA}

Sesi kelompok kerja lebih berorientasi teknis daripada sesi pleno. Kelompok kerja sebaiknya beranggota tidak lebih dari 15 orang. Anggota kelompok kerja perlu diberikan kebebasan untuk menyatakan keraguan/kritik terhadap K\&I tertentu yang diusulkan oleh tim pakar, yang relevan dengan tugas kelompok kerja.

Anggota tim pakar yang relevan sebaiknya menjadi anggota kelompok kerja yang tepat memberikan penjelasan/klarifikasi terhadap K\&I yang diamati dan sebaiknya menerangkan cara-cara proses pencapai keputusan. Namun 
penjelasan ini tidak dipandang sebagai pertahanan akhir, tetapi lebih sebagai proses pengesahan.

Pakar sebaiknya memperkenalkan dirinya sendiri pada awal kelompok kerja.

Masing-masing kelompok kerja akan memiliki ketua dan penulis. Ketua akan memimpin rapat kelompok. Penulis diharapkan akan mencatat temuantemuan kelompok kerja dan menyajikannya pada sesi pleno lokakarya. Jika diperlukan, pencatatan dilakukan oleh beberapa orang, jika ada beberapa bahasa yang digunakan.

Biasanya pakar anggota tim tidak boleh mengetuai rapat kelompok kerja karena mereka perlu membahas isu-isu teknis dalam sesi. Namun, mungkin akan membantu jika pakar anggota tim menjadi penulis. Pakar anggota tim biasanya dibutuhkan untuk membantu mempersiapkan laporan kelompok kerja. Anggota tim maupun ketua diharapkan sebanyak mungkin memudahkan dialog di antara peserta.

\subsubsection{PENGELOLAAN KONFLIK}

Dengan subyek seperti pengelolaan hutan lestari, konflik dalam kelompok kerja sangat mungkin terjadi. Pengalaman pengujian CIFOR memperlihatkan bahwa konflik ini sering berkisar sekitar isu-isu yang berkaitan dengan K\&I sosial dan ekologis. Semuanya dipecahkan dengan intervensi ketua. Oleh karenanya kami tidak yakin apakah perlu memakai jasa seorang fasilitator profesional. Jika timbul masalah ketua dapat mencoba untuk:

- mencegah beberapa individu mendominasi diskusi, khususnya dengan menanyakan orang yang pendiam tentang pandangan pribadi mereka; 
- menangguhkan isu-isu yang menjadi sumber perdebatan, dengan mengatakan 'kami setuju dengan ketidaksetujuan ini';

- buatlah jadwal waktu informal untuk membahas semua K\&I dan menggunakannya sebagai alasan untuk terus melanjutkan, jika terjadi kemacetan - perbedaan-perbedaan yang muncul dapat didokumentasikan dalam laporan; atau

- ingatkan para peserta perlunya mengakhiri perdebatan dan mulai menyiapkan laporan.

\subsubsection{PERSIAPAN LAPORAN AKHIR}

Berdasarkan hasil dari ketiga filter, pemimpin tim pakar diharapkan menyiapkan laporan akhir. Tujuan utama laporan akhir adalah untuk menyajikan K\&I yang diusulkan oleh tim pakar dan menjelaskan cara-cara dalam pengembangan K\&I. Laporan ini sebaiknya disiapkan dalam satu bulan setelah lokakarya berakhir. Pembaca laporan ini bervariasi, bergantung pada siapa yang menginginkan pengujian tersebut dan mengapa. Laporan ini umumnya disiapkan untuk: para pengelola hutan, lembaga-lembaga sertifikasi, proyekproyek, pemerintah, donor dan akademisi.

Laporan ini paling sedikit berisi:

- pengantar tentang sasaran pengujian;

- uraian lokasi dan sifat/ciri-ciri penting (manusia, ekologi, pengelolaan hutan);

- uraian metode yang digunakan;

- hasil pengujian termasuk set K\&I yang diusulkan; dan

- pembahasan. 


\section{Analisis Lanjutan}

\subsection{SETELAH LOKAKARYA}

Setelah pembuatan laporan lokakarya, ketua tim pakar akan menyiapkan laporan akhir yang berisi kumpulan laporan lokakarya dan informasi lain yang muncul dalam seluruh proses pengujian. Setelah laporan ini diajukan, koordinator pengujian K\&I mungkin akan menyunting laporan itu untuk menghasilkan versi terakhir. Pada saat ini $K \& I$ yang dipilih sebaiknya dapat digunakan dalam penilaian lokasi hutan yang bersangkutan.

Walaupun laporan ini menyajikan proses akhir dari pengujian lapang K\&I, ada kemungkinan yang melaksanakan pengujian berharap untuk mengadakan beberapa analisis lanjutan dan, ketua dan koordinator tim juga akan melakukan analisis sambil mengerjakan laporan mereka. Analisis dasar K\&I, dalam konteks proyek CIFOR, terutama terdiri dari uraian isi K\&I, tinjauan tingkat penerapan dan kajian konteks di mana K\&I dikembangkan.

Analisis semacam ini dapat bersifat subyektif sehingga perlu pemahaman analisis proses evaluasi K\&I. Pengujian K\&I merupakan suatu konsep, proses belajar tahap demi tahap. Para pakar, dipilih berdasarkan keahlian dan pengalaman pribadi mereka di wilayah yang bersangkutan, berusaha menerapkan K\&I pilihan di lapang. Selama proses ini mereka menerima, mengubah atau menolak K\&I setelah pengumpulan informasi kualitatif dan kuantitatif di lapang. Karena ini merupakan proses yang agak kompleks seseorang yang mengerjakan analisis lanjutan perlu memiliki pemahaman yang luas.

Kami merasa yakin, misalnya, bahwa bias isi analisis $K \& I$ yang diusulkan dalam kelompok CIFOR yang terdiri dari berbagai tim penguji K\&I 
telah diminimalkan karena kelompok kami diwakili oleh salah seorang atau, biasanya, dua orang dalam setiap pengujian. Karena itu kami dapat memahami konteks di mana K\&I dikembangkan dan isu-isu yang ingin ditangani. Kami merekomendasikan agar analisis lanjutan dari pengujian K\&I dilakukan oleh orang-orang yang benar-benar berpengalaman dengan pengujian lapang.

Dalam pembandingan hasil beberapa pengujian lapang K\&I tim CIFOR, fokus perhatian kami adalah pada proses bagaimana anggota tim lapang sampai pada kesimpulan mereka. Kami tetap ragu akan pilihan individu yang berbeda proses pengambilan keputusan yang mewakili perbedaan pendekatan/metode, subyek masalah, atau berbagai metode yang berkaitan dengan bidang mereka masing-masing. Memang, tiga hal tersebut mungkin merupakan faktor yang relevan dalam pengembangan indikator yang sederhana/ mudah, tepat sasaran dan hemat biaya. Karena isu ini memberikan kesempatan yang tepat untuk memperjelas beberapa perbedaan yang ditemui dalam pendekatan yang digunakan oleh anggota tim (di dalam CIFOR maupun tim lapang), diperlukan diskusi lebih lanjut.

Sebagaimana kami memiliki hierarki yang terdiri dari prinsip, kriteria, indikator dan kadang pengukur (verifier), kami juga memiliki hierarki pertanyaan penting untuk kategori ini dalam mengevaluasi kegunaannya. Pada tingkat prinsip dan kriteria, isu yang paling tepat untuk pemilihannya pasti yang berkaitan erat dengan kelestarian (termasuk definisi kami tentang kesejahteraan masyarakat). Kita harus bertanya pada diri sendiri beberapa pertanyaan tentang prinsip dan kriteria yang sudah ada. Misalnya: ${ }^{9}$

9 Lihat pembahasan yang lebih terinci tentang pertanyaan ini dalam Bab 5.3.1. 
- Apakah prinsip atau kriteria ini berhubungan dengan proses yang mungkin mengarah kepada kelestarian?

- Apakah mewakili bukti-bukti yang mendukung bahwa sistem yang lestari sudah ada?

- Dapatkah hubungan sebab/akibat ditunjukkan antara kriteria dan kelestarian (termasuk bukti secara logis, empiris atau kronologis yang masuk akal dari hubungan tersebut)?

- Apakah kondisi ini perlu atau cukup agar kelestarian dapat tercapai?

- Apakah prinsip atau kriteria ini khas dan/atau cukup penting dibandingkan dengan prinsip dan kriteria lain yang sedang diteliti?

Pada hierarki yang lebih rendah sampai indikator dan pengukur, jenis pertanyaan kita akan berubah. Satu pertanyaan yang terpenting sekarang adalah relevansi K\&I untuk menentukan syarat-syarat yang disebutkan dalam tingkat/level hierarkis di atas. Apakah indikator, misalnya, terkait jelas dengan kriteria yang rancangan pemenuhannya ingin dipastikan? Juga, adakah bukti secara logis, empiris atau kronologis yang masuk akal dari hubungan tersebut? Apakah indikator perlu atau cukup untuk menunjukkan adanya kriteria yang bersangkutan?

Hal lain dalam memilih K\&I adalah sebuah evaluasi keyakinan bahwa indikator, pengukur dan ukurannya (atau penentuan) secara akurat akan mencerminkan persyaratan K\&I di lapang. Beberapa variabel yang dapat mempengaruhi pengukuran hasil telah diidentifikasi (contoh: kemudahan dan kehematan biaya pengumpulan data, perlunya pengalaman dan penilaian). Berbagai kebutuhan masyarakat yang akan melakukan evaluasi di masa depan juga akan mempengaruhi pemilihan K\&I yang tepat, karena masing-masing evaluator mempunyai sumber daya, keinginan, kebutuhan dan persepsi. Siapa yang akan melakukan evaluasi ini, dan apakah interpretasi mereka tentang 
K\&I berbeda dari yang dimiliki oleh orang-orang yang mengembangkannya? Apakah K\&I cukup spesifik untuk mengatasi kesulitan ini? Apakah ada kesulitan?

Tidak ada jalan untuk menghindari pengambilan keputusan yang 'spesifik konteks' secara utuh. Walaupun ada jalan tengah dari K\&I umum yang dapat berguna bagi banyak evaluasi kelestarian hutan, ada juga indikator-indikator spesifik lokasi yang mungkin lebih dekat dengan 'tipe ideal' untuk lokasi khusus. Di Brasil, misalnya, sangat mungkin untuk mengganti satu indikator spesifik lokasi (mengacu pada tata cara keamanan pekerja lokal yang komprehensif) untuk serangkaian indikator yang lebih umum mengenai keamanan pekerja. Demikian pula serangkaian K\&I umum untuk pengelolaan hutan yang digunakan di lokasi lain dapat digolongkan di bawah satu sistem, yaitu TPTI Indonesia. Untuk alasan ini, hampir pasti bahwa setiap orang yang mengevaluasi prinsip, kriteria dan indikator akan perlu menyesuaikan set K\&I umum untuk penggunaannya sendiri.

Suatu referensi yang bermanfaat selama analisis ini, adalah makalah kerangka kerja hierarki Tropenbos (Lammerts van Bueren dan Blom 1997).

\subsection{BEBERAPA TAMBAHAN SEBAGAI PERTIMBANGAN}

Pembahasan terhadap subyek berikut dapat dipertimbangkan sebagai analisis lebih lanjut hasil dari pengujian K\&I dan set K\&I yang dihasilkannya.

Mengidentifikasi kemungkinan tumpang tindih dan kelebihan di antara K\&I

Dalam mengidentifikasi tumpang tindih dan kelebihan di antara K\&I, data yang tercatat dalam kotak penghubung Formulir 2 dapat digunakan sebagai 
landasan awal. Data ini dapat disajikan secara grafik. Lihat Lammerts van Bueren dan Blom (1997) sebagai contoh hierarki yang 'benar' dan 'salah' serta komentar tentang isu-isu serupa. Apakah tumpang tindih dapat dihindari dalam K\&I pilihan? Jika ya mengapa proses pengujian K\&I tidak menghilangkan tumpang tindih?

\section{Mengkaji kebutuhan konsistensi vs fleksibilitas dalam menggunakan hierarki prinsip, kriteria, indikator dan pengukur}

Selama rangkaian pengujian CIFOR, kami menemukan bahwa walaupun seluruh anggota tim dapat menempatkan $K \& I$ ke dalam sebuah kerangka kerja hierarkis, kategori yang ditetapkan dalam masing-masing konsep dalam hierarki mungkin berbeda dari kriteria untuk indikator dan untuk pengukur, tergantung pada lokasi dan pakar tersebut.

Dalam rangka mengembangkan konsistensi dalam penggunaan prinsip, kriteria, indikator dan pengukur kami menyarankan model informasi dasar dan pengolahan informasi yang diuraikan oleh Liang (1994) sebagai alat bantu yang sangat bermanfaat. ${ }^{10}$ Ia mengidentifikasi empat komponen dasar dari hierarki secara menarik: data, informasi, pengetahuan dan kearifan. Dalam definisi modelnya, Liang menegaskan bahwa informasi mengandung khususnya 'pesan tunggal' daripada elemen data yang hanya berisi 'nilai tunggal'. Di lain pihak pengetahuan adalah sebuah kombinasi selektif skala besar dari bagian informasi yang saling berhubungan, contoh: ilmu fisika. Akhirnya, kearifan dirasakan sebagai tambahan pengetahuan seseorang yang diperoleh melalui kemampuan deduktif intelektual setelah seseorang mencapai tingkat pemahaman yang memadai tentang suatu bidang

\footnotetext{
${ }^{10}$ Lihat juga pembahasan dalam Bab 5.2.
} 
pengetahuan. Jika kita mencoba mencocokkan berbagai elemen kerangka kerja konsep ke dalam kategori model komponen dasar ini, kita akan melihat bahwa kriteria dan indikator mencerminkan kearifan dan pengetahuan, sedangkan indikator dan terutama pengukur dapat diklasifikasikan sebagai informasi atau data menurut hierarki Liang.

Tetap ada kecenderungan hierarki diadaptasi di lokasi khusus. Kriteria mana yang dapat menjadi pengukur, dan sebaliknya, tergantung pada titik kritis yang dirasakan dalam pengujian lapang. Meskipun dalam hal-hal tertentu, set K\&I tetap merupakan 'bahan baku' yang sama, tetapi K\&I dapat dibentuk oleh para pakar sesuai topografi di dunia nyata.

\section{Mengidentifikasi kesenjangan dalam K\&I}

Kegiatan lain yang berguna adalah menggunakan panduan FSC dan ITTO untuk menentukan kesenjangan yang terjadi, jika ada, biarkan K\&I dipilih oleh tim pakar. Mengapa ada kesenjangan? Bagaimana proses pengujian dapat diperbaiki untuk menghindari kesenjangan ini?

\section{Mengembangkan dan mengoptimalkan prinsip, kriteria, indikator dan pengukur dari hasil pengujian lapang}

Berdasarkan informasi di atas, seluruh sasaran selanjutnya mungkin untuk mengembangkan dan mengoptimalkan hasil pengujian lapang set $K \& I$. Secara khusus hal ini penting di mana kasus-kasus ini terjadi, dengan beberapa alasan, pengujian lapang terbukti salah. Misalnya, menghasilkan banyak kesenjangan dalam keterkaitan antara $K \& I$ dan pengelolaan hutan lestari. Namun, dalam memodifikasi hasil pengujian lapang set K\&I harus dilakukan secara hati-hati. Jika modifikasi ini dilakukan dengan hati-hati, akan menghasilkan set K\&I yang baik. 


\section{Mengkaji kasus untuk K\&I umum dan spesifik lokasi}

Kegiatan lainnya yang berguna adalah mengkaji set K\&I untuk elemenelemen umum dan spesifik lokasi. Beberapa set K\&I dasar digunakan sebagai landasan awal. Apakah ini berguna? Elemen-elemen mana yang paling banyak memerlukan penyesuaian dengan kondisi lokal? Dapatkah set akhir diterapkan untuk wilayah yang lebih luas? Dalam batas-batas apa? Adakah sebuah set K\&I yang universal?

\section{Menghubungkan K\&I tingkat UPH dan tingkat nasional}

Dalam beberapa kasus (misalnya, set FSC, Montreal atau Helsinki yang 'kurang' berhasil) juga bermanfaat untuk mengkaji kaitan antara set K\&I nasional dan UPH. Apakah set nasional realistis? Berguna? Dalam kondisikondisi seperti apa? Pada tingkat hierarki mana set K\&I nasional atau UPH yang paling tepat? 


\section{Konsep Dasar Pengembangan K\&I}

\subsection{MENAFSIRKAN PENGELOLAAN HUTAN LESTARI}

Seperti pernyataan Wiersum (1995): 'usaha untuk menelaah konsep kelestarian sudah dilakukan selama 200 tahun, penerapannya di bidang kehutanan tetap mengalami banyak masalah'. Beberapa definisi terbaru ${ }^{11}$ tentang pengelolaan hutan lestari telah diusulkan (contoh: ITTO 1991). Kebanyakan definisi ini berakar pada konsep pembangunan lestari yang dinyatakan dalam Laporan Komisi Brundtland (Komisi Dunia untuk Lingkungan dan Pembangunan 1988)..$^{12}$

Untuk mengembangkan sebuah sistem penilaian, kami mendefinisikan pengelolaan hutan lestari sebagai:

Suatu rangkaian sasaran, kegiatan dan hasil yang selalu melihara dan meningkatkan integritas ekologis hutan dan memberi andil bagi kesejahteraan masyarakat baik di masa sekarang maupun di masa depan.

${ }^{11}$ Prinsip kelestarian memiliki sejarah panjang di Jerman dan Perancis pada abad 17. Definisi modern yang paling awal dituliskan kembali oleh Hartig (1804) di Jerman: '...manfaatkan [hutan] sebesar-besarnya, tetapi dengan cara-cara yang membuat generasi yang akan datang paling sedikit tetap memiliki keuntungan yang sama seperti generasi sebelumnya' (dikutip dari Schmutzenhofer 1992).

12 'Pembangunan lestari adalah pembangunan yang memenuhi kebutuhan sekarang tanpa mengorbankan kemampuan generasi yang akan datang untuk memenuhi kebutuhan mereka sendiri' (Komisi Dunia untuk Lingkungan dan Pembangunan 1988: 43). 
Definisi ini mewakili definisi-definisi umum yang lain tentang pengelolaan hutan lestari yang telah kami kaji. Oleh karena itu tugas untuk mengevaluasi kelestarian pengelolaan hutan adalah untuk menilai dua kondisi berikut, bahwa:

- integritas ekosistem dipertahankan atau ditingkatkan; dan

- kesejahteraan masyarakat dipertahankan atau ditingkatkan.

Kedua kondisi ini mewakili elemen biofisik, sosial dan temporal dari kelestarian dan dibahas di bawah secara lebih terinci. Dari cara pandang yang pragmatis dan operasional, pemenuhan dua kondisi di atas diharapkan terjadi secara terus-menerus selama jangka waktu yang tidak terbatas (mungkin sepuluh sampai seratus tahun). Kami juga mengalami kemungkinan adanya konflik jangka pendek dan spesifik lokasi di antara dua sasaran ini, dan bahwa penentuan keseimbangan yang tepat mungkin menjadi masalah bagi para penilai.

Karena proyek ini difokuskan pada unit pengelolaan hutan, maka definisi UPH ini perlu diberikan dengan jelas. Definisi ini mempunyai konsekuensi penting untuk penilaian pengelolaan hutan lestari.

Sebuah UPH didefinisikan sebagai:

Kawasan hutan yang batas-batasnya jelas, sebagian besar lahannya tertutup oleh hutan, dan dikelola untuk berbagai tujuan yang dinyatakan secara jelas dan didasarkan pada rencana pengelolaan jangka panjang. 
Sebuah UPH biasanya berukuran beberapa ratus hektar ${ }^{13}$ sampai beberapa ratus ribu hektar. Seluruh kawasan UPH harus memiliki batas-batas yang jelas di lapangan dan juga di atas peta. Di bawah sasaran yang luas dan ingin dicapai oleh unit pengelolaan, beberapa subunit mungkin dikelola di bawah rejim pengelolaan yang berbeda dan terpisah. Rencana pengelolaan biasanya dalam bentuk tertulis dan kadang diterbitkan. Meskipun tertulis dan diterbitkan bukan merupakan syarat penting.

Pengelolaan UPH memiliki implikasi terhadap masyarakat yang hidupnya bergantung pada sumber daya hutan dan sebaliknya. Masyarakat ini bermukim di dalam atau di luar batas-batas fisik UPH, tetapi dampak kegiatan pengelolaan dapat meluas serta melintasi batas-batas UPH yang resmi. Bahkan, dampak ini mungkin merupakan dampak sosial, dan juga fisik atau ekologis, dan dapat mempengaruhi nilai material, budaya dan sosial. Tim penguji mencoba untuk menentukan berbagai dampak ini berdasarkan perbedaan kepentingan dengan menggunakan sebuah metode yang sedang dikembangkan oleh Colfer (1995).

\subsubsection{INTEGRITAS EKOSISTEM}

Schneider (1992) mendefinisikan integritas ekosistem sebagai:

kemampuan untuk mendukung dan memelihara keseimbangan, integrasi komunitas kehidupan hayati yang memiliki komposisi jenis, keanekaragaman dan berbagai fungsi yang seimbang, terpadu, seperti kondisi habitat alami di wilayah tersebut.

13 Walaupun suatu UPH mungkin hanya seluas beberapa ratus hektar, diasumsikan bahwa dalam kebanyakan kasus, UPH ini merupakan bagian dari sebuah kawasan berhutan yang lebih luas. Namun, bukan maksud kami untuk mengartikan bahwa petak hutan yang berukuran beberapa ratus hektar dapat dikelola kelestariannya secara mandiri, tetapi ada kemungkinan unit pengelolaan adalah sekecil ini. 
Sebuah istilah alternatifnya adalah kesehatan ekosistem, yang didefinisikan sebagai:

suatu ukuran komprehensif, berbagai skala, syarat hierarkis terhadap stabilitas sistem, pengaturan dan kekokohan sistem (Constanza 1992).

Dua definisi ini menyatakan bahwa struktur, fungsi dan ketahanan (resiliensi) ekosistem merupakan dimensi yang perlu diperhatikan dalam pengelolaan ekosistem. Proyek ini didasarkan pada definisi berikut:

Ekosistem: Komponen biotik dan abiotik dari suatu lingkungan yang berinteraksi untuk menghasilkan aliran energi dan daur hara. Secara praktis ekosistem sangat sulit didefinisikan karena tingginya tingkat variasi, perubahan menurut waktu dan langkanya ciri-ciri yang tersendiri. Proyek telah menjadikan batas-batas fisik UPH sebagai batas eksternal dari ekosistem hutan di mana K\&I diujikan dan dikembangkan. Seperti kasus merembetnya dampak sosial, bukan berarti interaksi tingkat lansekap diabaikan. Namun secara praktis fokus utamanya adalah interaksi dalam batas-batas fisik suatu unit pengelolaan hutan.

Struktur: Komposisi jenis, pola penyebaran dan pengaturan jenis tumbuhan dan binatang ke dalam tingkat yang lebih tinggi, seperti tingkat trofik, jaring atau guild makanan. Perubahan struktural parameter menurut waktu adalah unsur penting ekosistem dalam jangka panjang (Landres 1992).

Fungsi: Serangkaian proses yang merupakan hasil interaksi di antara komponen-komponen biotik dan abiotik dalam ekosistem. Empat kelas proses yang penting:

- proses yang mempengaruhi laju dan kuantitas total aliran energi;

- proses yang mempengaruhi laju dan kuantitas total dari daur hara; 
- proses yang mempengaruhi berbagai jasa ekosistem yang penting bagi kehidupan manusia (Landres 1992); dan

- proses yang mempengaruhi kehidupan dan keanekaragaman organisme hidup dalam jangka pendek dan jangka panjang.

Ketahanan: Kemampuan sistem untuk menyerap perubahan variabel dan parameter keadaan, dan tetap melakukannya atau bertahan dalam beberapa lama. Juga dapat didefinisikan sebagai persistensi hubung-an di dalam suatu sistem atau kemampuan ekosistem untuk pulih kembali. Istilah yang berkaitan adalah stabilitas, elastisitas dan waktu pemulihan. Di lain pihak, ketahanan berhubungan dengan sejauh mana ekosistem berubah di bawah kondisi tekanan (Attiwill 1994).

\subsubsection{KESEJAHTERAAN MASYARAKAT ${ }^{14}$}

Konsep 'kesejahteraan' meliputi aspek ekonomi, sosial dan budaya dalam kehidupan manusia, yang dipengaruhi oleh pengelolaan hutan. Pengelolaan hutan secara alami bertujuan untuk memberikan berbagai manfaat bagi manusia, walaupun, menurut pendapat Colfer (1995) berapa banyak manfaat atau keuntungan dan siapa yang akan menikmatinya masih merupakan pokok perdebatan, terutama pada lahan yang diklasifikasikan sebagai hutan milik umum. Tidak realistis bila mengharapkan pengelola hutan memecahkan semua masalah masyarakat, tetapi pada suatu kesempatan, anggota tim, peserta lokakarya dan lainnya menunjukkan harapan seperti ini.

${ }^{14}$ Menurut Wollenberg dan Colfer (1996). 


\section{Masyarakat yang mana?}

Suatu analisis yang teliti diperlukan untuk menentukan kelompok sosial mana yang membutuhkan perhatian pengelola hutan. Satu elemen kritis adalah kedekatan dengan hutan. Masyarakat yang hidup dekat hutan memiliki potensi terbesar untuk mempengaruhi hutan secara langsung. ${ }^{15}$ Namun, ada beberapa ciri penting lain yang muncul selama penelitian kami. Termasuk di dalamnya: hak-hak yang sudah ada, ketergantungan terhadap hutan, pengetahuan indijenus, integrasi budaya-hutan dan defisit kekuasaan. Menurut kami ‘keprihatinan tentang kelestarian' dan ‘kemiskinan' mungkin perlu ditambahkan dalam daftar ini (Colfer 1995).

Setelah pengamatan-pengamatan tersebut, kami mulai mengembangkan metode sederhana untuk mengidentifikasi kelompok masyarakat yang dipengaruhi oleh pengelolaan hutan tertentu, sebagian untuk mengurangi harapan-harapan yang selama ini ditujukan secara tidak adil kepada pengelola hutan, dan sebagian untuk memastikan agar populasi penduduk yang relevan mendapat perhatian. Definisi yang lebih luas tentang unit pengelolaan hutan yang bersangkutan, dari sudut pandang sosial, dapat diperoleh dengan menerapkan metode ini seperti yang diuraikan dalam Bagian 'Mengidentifikasi Stakeholder dan Para Pengelola Hutan' pada hal. 43 (menurut Colfer dkk. 1996).

\section{Dimensi Manusia dan Pengelolaan Hutan Lestari}

Waktu pertama kali menginvestigasi dimensi manusia dalam pengelolaan hutan lestari, kami menemukan dua aspek penting yang berbeda tentang konsep kelestarian. Dari perspektif sosial, kelestarian dapat dikatakan meliputi:

15 Pengertian di sini adalah pengaruh lokal langsung. Sangat mungkin bahwa pembuat kebijakan, misalnya, dapat memberikan dampak keseluruhan yang lebih besar. 
- pemeliharaan kesejahteraan masyarakat - sering terfokus pada masyarakat yang hidup di hutan; dan

- kegiatan masyarakat yang mempengaruhi kelestarian hutan.

\section{Apa yang Mempengaruhi Kesejahteraan Masyarakat?}

Suatu tinjauan terhadap prinsip-prinsip pengelolaan hutan lestari yang ada dan pustaka umum tentang masyarakat hutan, menyajikan lima bidang penting yang berkaitan dengan kesejahteraan masyarakat. Bidang ini dapat dianggap sebagai ‘Rancangan Hak-Hak Kelestarian yang Tidak Tetap'.

- Keamanan dan kecukupan akses terhadap sumber daya. Akses sebaiknya dinilai pada masa sekarang maupun di masa depan, termasuk distribusi manfaat antargenerasi, misalnya, definisi Komisi Brundtland (Komisi Dunia untuk Lingkungan dan Pembangunan 1988) tentang pemenuhan kebutuhan saat ini tanpa membahas kebutuhan masa depan.

- Peluang Ekonomi. Kegiatan yang terkait dengan hutan harus mempertahankan atau meningkatkan berbagai peluang mata pencaharian masyarakat.

- Warisan dan identitas. Hak-hak masyarakat terhadap nilai kebudayaan mereka, kebiasaan, penggunaan lahan dan materi dari hutan harus dihormati, untuk waktu sekarang maupun dalam konteks untuk mempertahankan budaya bagi generasi muda.

- Keadilan. Harus ada pemecahan konflik serta pembagian keuntungan, hak-hak, tanggung jawab dan insentif secara adil.

- Keamanan dan kesehatan. Pekerjaan, tempat tinggal di dalam hutan atau pemanfaatan hutan tidak boleh mengancam keamanan dan kesehatan masyarakat (secara fisik maupun mental). 
Dengan kata lain, jika lima syarat umum ini berhasil maka kelestarian hutan tersebut, dari perspektif sosial, pasti tercapai.

Distribusi keuntungan antargenerasi adalah sebuah komponen kesejahteraan masyarakat yang penting karena fokusnya adalah ketahananan atau pengembangan keadilan sosial secara terus-menerus. Indikator-indikator untuk menilai keuntungan antargenerasi meliputi stabilitas kesejahteraan masyarakat, pemeliharaan 'modal sosial', ${ }^{16}$ sistem pembagian warisan/ peninggalan yang adil, dan keamanan hak pemilikan dan nilainya, serta kesempatan yang tersedia untuk generasi yang lebih muda.

\section{Bagaimana Masyarakat Mempengaruhi Hutan}

Masyarakat dapat mempengaruhi kelestarian hutan melalui partisipasi aktif dalam pengelolaan (atau kesalahan pengelolaan) maupun melalui berbagai aspek kehidupan normal mereka seperti pembangunan rumah, pengumpulan kayu bakar atau pemanfaatan hutan lainnya. Dalam pengembangan kesejahteraan masyarakat lebih lanjut dan pengaruh masyarakat terhadap hutan, kami menemukan bahwa definisi Ostrom (1994) relevan untuk memahami bagaimana kegiatan-kegiatan masyarakat lokal dapat mempengaruhi pengelolaan hutan secara positif (atau sumber daya lain) di bawah pengendalian/kontrol kolektif/bersama mereka. Ia menguraikan delapan 'prinsip rancangan' yang jika dipenuhi akan mengarah kepada pengelolaan efektif

16 Ostrom (1994: 20), dari Coleman (1988) dan Putnam (1993), menyebutkan 'Modal sosial adalah pengetahuan, pengertian, dan pola interaksi yang dimiliki bersama oleh sekelompok individu untuk diterapkan dalam berbagai kegiatan yang produktif ... yang diciptakan saat individu belajar saling percaya sehingga mereka dapat membuat komitmen yang sungguhsungguh dan bergantung pada bentuk/sistem saling membalas budi daripada hubungan pendek dari satu pihak dengan pihak tertentu lainnya'. 
sumber daya lokal milik bersama. Dengan mengembangkan idenya dan ide penulis lainnya tentang pengelolaan sumber daya milik bersama, kami mengidentifikasi paling sedikit sembilan syarat sosial yang diperlukan untuk pengelolaan efektif sumber daya oleh suatu kelompok.

- Batas-batas didefinisikan secara jelas dan disepakati. Hak-hak guna dan pembagian keuntungan didefinisikan secara jelas dan disepakati.

- Kemampuan melindungi sumber daya. Para pengguna hutan memiliki kemampuan untuk melarang orang luar masuk.

- Mekanisme pengambilan keputusan. Masyarakat yang dipengaruhi oleh hutan dapat mengatakan bagaimana cara mengelola sumber daya dan bagaimana pembagian keuntungannya. Mereka juga memiliki kemampuan kelompok dalam membuat keputusan akhir.

- Penyelesaian konflik sangat berkaitan dengan pengambilan keputusan. Masyarakat memiliki kemampuan untuk menyelesaikan konflik, secara internal maupun eksternal bagi kelompok tersebut.

- Pemantauan. Informasi tentang kualitas sumber daya bagi kelompok tersebut tersedia.

- Ukuran kelompok dan organisasi. Kelompok-kelompok ini umumnya cukup kecil sehingga memungkinkan kontak komunikasi yang teratur. Jika jumlah orang yang terlibat cukup besar, maka kelompok-kelompok dikumpulkan untuk meningkatkan efisiensi pengaturan.

- Insentif/keuntungan. Keuntungan bersih bagi masyarakat adalah positif dan dapat mencakup keuntungan ekonomi dan juga budaya atau halhal yang bukan berupa materi. Insentif bisa positif atau negatif (contoh: sanksi). Pilihan-pilihan pengelolaan hutan sebaiknya dipertimbangkan setelah dibandingkan dengan hasil keuntungan dari berbagai kegiatan lain (opportunity cost). 
- Berbagai bentuk masukan. Masyarakat memiliki tenaga, teknologi, informasi, dan modal atau masukan yang cukup, yang diperlukan untuk pengelolaan lestari.

- Nilai pelestarian/konservasi atau komitmen terhadap kelestarian. Masyarakat yang menggunakan hutan menghargai kelestarian hutan dan mencari cara-cara untuk memelihara kualitas sumber daya.

Walaupun tidak semua hutan dikelola sebagai sumber daya milik bersama, banyak situasi pengelolaan hutan yang kami temui menghadapi komponen pengelolaan milik bersama yang kuat. ${ }^{17}$ Karena itu daftar 'syarat-syarat sosial' sangat berguna dalam menilai kelestarian sebagian besar kawasan hutan. Bahkan kenyataannya, jika syarat-syarat ini dipenuhi, maka aspek negatif yang dirasakan dalam pemanfaatan hutan oleh masyarakat dapat diminimalkan.

\subsubsection{ASPEK KONTINUITAS DAN WAKTU}

Aspek kontinuitas dan waktu mempengaruhi elemen biofisik maupun elemen sosial dalam pengelolaan hutan lestari. Dari segi penilaian biofisik, perlu dipahami bahwa kontinuitas bukan berarti aliran barang dan jasa secara konstan. Sebagaimana sistem alami yang dinamis, keluaran dari hutan yang dikelola secara lestari akan berfluktuasi. Namun demikian, tingkat fluktuasi ini harus dikendalikan sehingga sistem ini tetap stabil. Fluktuasi ini sebaiknya berada dalam kisaran yang dapat diperkirakan secara relatif selama jangka waktu yang lama.

Sistem-sistem sosial juga memerlukan suatu keseimbangan antara stabilitas dan perubahan. Sementara dalam sistem sosial tertentu masih ada kesem-

${ }^{17}$ Contohnya, hutan secara resmi sering di bawah pengelolaan HPH, tetapi masyarakat lokal terus mengambil hasil hutan dan menjalankan praktek pengelolaan hutannya sendiri. 
patan terjadinya fluktuasi dalam suatu periode waktu tertentu, jika batas dilewati maka sistem yang sehat hancur. Karena kehancuran ini dapat mengganggu sistem pengelolaan hutan secara serius maka satu tugas penting dalam mengembangkan dan menilai K\&I sosial adalah mendapatkan indikator yang memberitahukan kita bahwa batas sistem sosial yang stabil hampir dicapai atau telah dilampaui.

Inti kelestarian adalah pemeliharaan kondisi yang diinginkan sepanjang waktu. Kondisi ini dapat dipertahankan melalui berbagai faktor K\&I yang diukur. Misalnya, keadilan antargenerasi adalah salah satu prinsip yang sebaiknya mencerminkan stabilitas sistem jangka panjang. Namun, keandalan K\&I dalam mengevaluasi prinsip ini perlu dipikirkan. Keandalan seperti ini diharapkan berkurang secara cepat sepanjang waktu karena ada sifat ketidakpastian dalam membuat prediksi/perkiraan tentang interaksi sosial dan ekosistem yang kompleks. Untuk itu kami merekomendasikan masa berlaku dan keabsahan penilaian kelestarian maksimum lima tahun.

\subsection{MEMAHAMI PRINSIP, KRITERIA, INDIKATOR DAN PENGUKUR}

Pada bagian ini, kami mendefinisikan tiga konsep utama untuk memandu penilaian, yaitu: prinsip, kriteria dan indikator. Kami juga mendefinisikan dan membahas pengukur dan prosedur pengukuran. Hubungan antara elemenelemen ini disajikan dalam Gambar 4.

Definisi berikut digunakan oleh tim penguji dalam penilaian K\&I.

Prinsip: Suatu kebenaran atau hukum pokok sebagai dasar suatu pertimbangan atau tindakan. Prinsip-prinsip dalam konteks pengelolaan hutan 
Gambar 4. Konsep Kerangka Kerja

\section{Prinsip}

Kelestarian

Kriteria

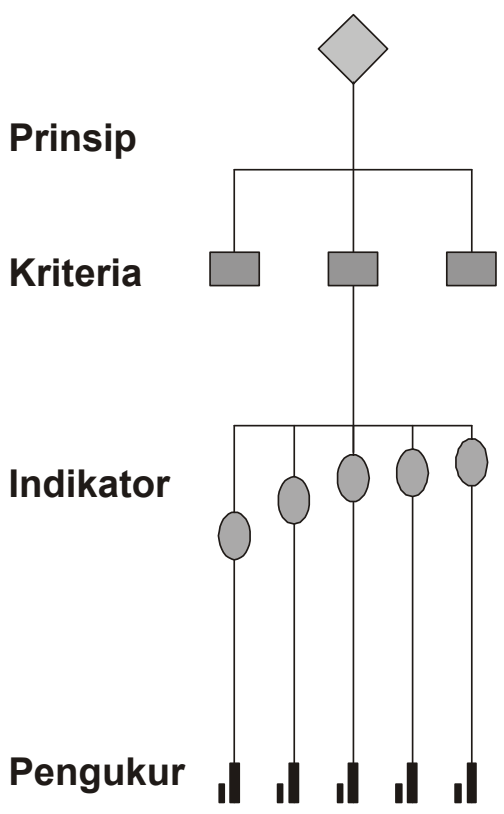

Mengidenfitikasi komponen kritis Pengoperasian 'kelestarian'

Memberikan 'endpoint' hierarkis

Memberikan identitas yang dapat dikenali

Memberikan elemen

\section{Indikator}

Pengukur

\section{Perangkat primer evaluasi}

Lokasi spesifik (atau generik)

Diurutkan menurut kepentingan

Kemungkinan kaitan silang

Kemungkinan pembagian

informasi

Lokasi yang sangat ekstrim

Titik ambangnya dapat ditentukan 
lestari diperlakukan sebagai kerangka primer untuk mengelola hutan secara lestari. Prinsip-prinsip tersebut memberikan landasan pemikiran bagi Kriteria, Indikator dan Pengukur. Prinsip dapat dianggap sebagai kearifan manusia. Kearifan di sini didefinisikan sebagai pertambahan pengetahuan seseorang atau suatu kelompok yang dihasilkan oleh kemampuan dalam mengambil kesimpulan setelah mereka memiliki tingkat pemahaman yang mamadai tentang suatu bidang pengetahuan. Oleh karena itu kearifan sangat dipengaruhi oleh pengetahuan.

Contoh prinsip: ${ }^{18}$

- agar pengelolaan hutan lestari dapat berlangsung, maka 'integritas ekosistem harus dipelihara atau ditingkatkan'; atau

- agar pengelolaan hutan lestari dapat berlangsung, maka 'kesejahteraan masyarakat harus terjamin'.

Kriteria: Suatu prinsip atau patokan untuk menilai suatu hal. Suatu Kriteria oleh karenanya dapat dilihat sebagai prinsip 'tingkat dua' yang menambah arti dan cara kerja pada suatu prinsip tanpa membuatnya sebagai suatu pengukur kinerja secara langsung. Kriteria merupakan titik lanjutan di mana informasi yang diberikan oleh Indikator dapat digabungkan dan di mana suatu penilaian yang dapat dipahami menjadi lebih tajam. Prinsip-prinsip membentuk titik akhir integrasi. Di samping mempertimbangkan kriteria sebagai prinsip urutan kedua, kriteria juga dapat diperlalukan sebagai cerminan dari pengetahuan. Pengetahuan adalah akumulasi informasi yang saling terkait, diperoleh dalam jangka waktu yang panjang. Pengetahuan juga dapat dipandang sebagai suatu kombinasi selektif atau kumpulan berbagai informasi yang saling terkait.

${ }^{18}$ Kalimat 'agar pengelolaan hutan lestari terjadi' dimasukkan di sini sebagai penjelasan. 
Contoh kriteria (diterapkan untuk prinsip pertama yang diberikan di atas):

- agar integritas ekosistem dipelihara atau ditingkatkan beberapa 'fungsi utama dan proses-proses ekosistem hutan harus dipertahankan'; atau

- agar integritas ekosistem dipelihara atau ditingkatkan beberapa 'proses yang melestarikan atau meningkatkan variasi genetis harus dipertahankan'

Indikator: Suatu Indikator adalah variabel atau komponen ekosistem atau sistem pengelolaan hutan apa saja yang digunakan untuk memperkirakan status Kriteria tertentu. Indikator membawa suatu 'pesan tunggal yang berarti'. 'Pesan tunggal' ini disebut informasi, yang mewakili suatu agregat dari satu atau lebih elemen data yang memiliki hubungan tertentu yang tetap.

Sebuah contoh indikator yang diterapkan dalam kriteria di atas:

- untuk memastikan bahwa berbagai proses yang melestarikan atau meningkatkan variasi genetis dipertahankan, kita dapat mempelajari 'perubahan yang terarah pada frekuensi allele atau genotipe'.

Pengukur: Data atau informasi yang meningkatkan spesifitas atau kemudahan penilaian suatu indikator. Pada tahap keempat pengukur memberikan perincian spesifik yang akan menunjukkan atau mencerminkan kondisi yang diinginkan dari suatu indikator. Pengukur memberi tambahan arti dan ketelitian pada suatu indikator. Pengukur ini mungkin juga memberikan pembatasan terhadap suatu hipotesis, di mana pemulihan kondisi masih dapat berlangsung (kinerja ambang batas/sasaran). Di sisi lain, pengukur ini juga dapat didefinisikan sebagai suatu prosedur yang diperlukan untuk menentukan tingkat kepuasan kondisi yang sudah disebutkan dalam indikator yang bersangkutan (cara-cara untuk melakukan pengukuran). 
Sebuah contoh pengukur yang diterapkan dalam indikator di atas:

- serubahan yang terarah pada frekuensi allele atau frekuensi genotipe dapat ditentukan melalui pengukuran 'jumlah allele dalam populasi' secara berkala.

Prosedur pengukuran adalah prosedur yang digunakan di lapang secara aktual, dengan fokus pada pengukur, untuk menentukan apakah syarat-syarat yang diusulkan dalam sistem evaluasi dapat dipenuhi. Misalnya, jika pengukurnya adalah 'fasilitas rumah yang memadai bagi staf dan paling sedikit memenuhi persyaratan legal minimum', maka cara pengukuran dapat dilakukan melalui 'wawancara dengan para pekerja dan pemeriksaan persyaratan kontrak'.

Prosedur pengukuran haruslah:

- hemat biaya - setelah K\&I diidentifikasi, sebagian besar biaya evaluasi bergantung pada prosedur apa yang diadopsi sebagai cara-cara pengukuran;

- cepat, sederhana dan mudah dipahami - ini penting jika pengukur ini secara efektif diikuti oleh tim evaluasi yang berbeda dan menghasilkan hasil yang konsisten; dan

- transparan dan masuk akal, agar dapat diterima. 


\subsection{PENENTUAN KESESUAIAN K\&I}

\subsubsection{SEMBILAN CIRI POKOK}

Sembilan ciri dipilih untuk menentukan tingkat kesesuaian K\&I yang diusulkan secara keseluruhan pada situasi tertentu. Selama rangkaian pengujian kami, anggota tim mempunyai persepsi yang berbeda tentang kegunaan sembilan ciri ini. Beberapa perbedaan bersumber dari perspektif disiplin ilmu. Cara lain evaluasi dibahas pada akhir bagian ini.

Ciri utama di bawah ini dipilih oleh tim proyek untuk digunakan oleh anggota tim dalam menentukan tingkat kesesuaian K\&I.

- Relevansi. Semua K\&I harus relevan dengan isu-isu yang berkaitan dengan pengelolaan hutan lestari.

- Secara gamblang berhubungan/berkaitan erat dan logis dengan sasaran penilaian. Setiap indikator harus berkaitan langsung dengan kriteria dan setiap kriteria berkaitan langsung dengan prinsip. Semua prinsip mempunyai tujuan akhir yang sama yaitu pengelolaan hutan lestari.

Walaupun serupa dengan ciri sebelumnya, yaitu relevansi, ciri ini menekankan posisi kriteria atau indikator di dalam suatu kaitan yang logis.

Ciri ini perlu karena, dalam proses mendefinisikan atau mengembangkan K\&I, hubungan yang tampaknya logis kadang dapat menutupi fakta bahwa suatu indikator tertentu sedikit sekali relevansi langsungnya dengan kelestarian. ${ }^{19}$

${ }^{19}$ Misalnya, kekuatan (HP) sebuah bulldozer sering dikaitkan dengan tingkat kerusakan yang ditimbulkannya, dan akhirnya terkait dengan kondisi suatu hutan, yang terkait dengan integritas ekosistem. Rangkaian yang tampaknya logis, membuat kekuatan (HP) bulldozer 
- Didefinisikan secara tepat. Penyusunan kata pada definisi kriteria sebaiknya sederhana dan gamblang.

- Spesifik berdasarkan diagnosis. Indikator dapat memberikan informasi sejauh mungkin untuk mendukung interpretasi langsung tentang pemenuhan syarat-syarat sebuah kriteria. Misalnya, indikator 'Suatu kawasan hutan permanen yang terdiri dari hutan lindung dan hutan produksi telah diberi wewenang ...' secara diagnostik spesifik terhadap kriteria 'Kerangka kerja legal dan kebijakan yang mengakui keuntungankeuntungan yang berasal dari hutan dan mempertahankannya secara optimis'. Namun, ini tidak selalu bisa dilakukan karena kekurangan informasi, atau biaya untuk penilaian langsung ini, di antara faktor-faktor lain (lihat juga komentar dalam Bagian 5.3.3).

Dalam kasus-kasus seperti itu, indikator perkiraan perlu didefinisikan. Indikator 'Bahan kimia yang dilarang di Eropa, Amerika atau negara tertentu tidak digunakan' adalah sebuah indikator perkiraan yang berusaha dikembangkan untuk ' ... tidak ada kontaminasi bahan kimia terhadap ... rantai makanan dan ekosistem'. Kedua indikator ini menilai pemenuhan kriteria 'Fungsi-fungsi ekosistem yang terpelihara'. Namun, penilaian tidak langsung ini harus diusahakan memenuhi ciri 'spesifikasi berdasarkan diagnosa' sebaik mungkin.

- Mudah dideteksi, dicatat dan ditafsirkan. Dalam kebanyakan kasus dana, untuk penilaian kelestarian harus dibiayai, secara langsung atau tidak,

dimasukkan dalam banyak set K\&I. Informasi ini dapat menyesatkan karena bukan hanya kekuatan (HP) bulldozer yang relevan dengan kelestarian, tetapi juga ketrampilan (contoh: pelatihan) dan komitmen pengemudi bulldozer. Kami percaya kombinasi beberapa ciri akan membantu mengungkapkan ketidak-konsistenan logis ini. 
dari penjualan produksi unit pengelolaan hutan. Jadi, indikator perlu dipilih sedemikian rupa sehingga hasilnya dapat dicapai dengan biaya tambahan minimum. Indikator-indikator yang mudah dideteksi, dicatat dan ditafsirkan akan memberikan andil yang cukup besar dalam mencapai sasaran hemat biaya.

- Dapat dipercaya. Teknik-teknik atau metode-metode yang diperlukan untuk memastikan informasi spesifik disebutkan dalam kriteria dan indikator yang harus dapat dipercaya, misalnya, seperti ditunjukkan oleh kemampuannya untuk diulang. Dengan kata lain, apakah kita mendapat jawaban yang sama pada waktu menerapkan kembali prosedur penilaian yang sama dalam kondisi yang sama?

- Kisaran respon yang memadai terhadap berbagai perubahan tingkat tekanan terhadap pengelolaan hutan, ekologis atau sosial. K\&I sebaiknya didefinisikan sedemikian rupa sehingga mencerminkan perubahan bertahap yang berarti sebagai tanggapan atas berbagai perubahan sistem. Walaupun dalam beberapa kasus sebuah jawaban sederhana ya/tidak mungkin berguna, dalam kebanyakan kasus dampak pengelolaan menghasilkan respon/tanggapan yang beragam menurut sistem yang mendasar. Sebuah indikator yang berguna akan memberikan informasi yang berarti tentang kisaran berbagai perubahan dalam sistem tersebut.

- Memberikan sebuah ringkasan atau ukuran yang terintegrasi menurut ruang dan/atau waktu. Ciri ini berkaitan dengan kuantitas sistem informasi yang terkandung dalam indikator tunggal. Beberapa indikator mengandung informasi yang berhubungan dengan sejumlah faktor.

Misalnya, indikator 'Vegetasi yang potensial mendominasi suksesi vegetasi sekunder yang tidak melimpah di tegakan bekas tebangan' mengintegrasi 
informasi gangguan yang diderita oleh hutan selama kegiatan eksploitasi. Kerusakan ini mencakup pembukaan sejumlah tajuk, gangguan pada tanah, kegiatan pemeliharaan, dll. Indikator-indikator ini, sering didefinisikan dalam hubungannya dengan titik-titik penyekik dalam sistem yang cenderung menjadi lebih informatif dan hemat biaya daripada yang lain (lihat juga 'kehematan biaya' di bawah). ${ }^{20}$

- Menarik bagi para pengguna. Ciri ini mengakui fakta bahwa orang-orang yang akan menerapkan K\&I perlu menerimanya sebagai ukuran yang penting, praktis dan logis. Para pengguna K\&I harus dapat menjawab 'ya' atas pertanyaan: Apakah rangkaian prinsip, kriteria, indikator, pengukur ini secara logis, praktis dan keuangan masuk akal bagi Anda? Misalnya, tim pakar kami sering ditanya untuk menilai kehematan biaya dari berbagai K\&I yang diamati mengingat bahwa kehematan biaya merupakan suatu faktor utama yang mempengaruhi penerimaannya. Isu yang berhubungan adalah apakah $\mathrm{K} \& \mathrm{I}$ dapat diterima oleh konsumen yang mungkin menerima atau menolak program sertifikasi berdasarkan daya tarik K\&I. ${ }^{21}$

\subsubsection{PERSPEKTIF LAIN UNTUK MEMBANTU IDENTIFIKASI DAN PENGEMBANGAN K\&IYANG LEBIH BAIK}

Dalam bagian ini kami membahas penilaian $K \& I$ dari empat perspektif: hubungan sebab-akibat yang terkait dengan pengelolaan hutan lestari; isi

\footnotetext{
${ }^{20}$ Namun, penting juga untuk mempertahankan rangkaian logis yang disebutkan dalam ciri 'Pendekatan dan penjelasan secara logis yang berkaitan dengan sasaran penilaian'.

${ }^{21}$ Misalnya, K\&I mengacu pada perlindungan jenis satwa liar tertentu lebih menarik daripada yang lain.
} 
informasi; klasifikasi waktu; dan klasifikasi menurut tingkat geopolitis. Setiap kriteria atau indikator dapat didefinisikan dengan cara yang berbeda tergantung perspektif yang dipilih. Beberapa hasil definisi yang berbeda hanya pada awal karena pilihan kata-kata yang berbeda. Namun dalam kasus lain, perbedaan-perbedaan perspektif cukup banyak mempengaruhi perumusan K\&I dan ini akan menghasilkan tipe indikator yang berbeda, dengan konsekuensi-konsekuensi yang dinilai, di mana, kapan dan bagaimana. Perbedaan perspektif ini akan mempengaruhi indikator dan ambang batas kinerja yang lebih banyak daripada pengaruhnya terhadap kriteria.

Kami menyarankan agar perspektif yang berbeda ini dapat digunakan sebagai alat bantu untuk mengidentifikasi dan mengembangkan K\&I yang lebih baik, bukan merupakan akhir perbedaan itu sendiri.

\section{Hubungan Sebab-Akibat dengan Pengelolaan Hutan Lestari}

Ada dua tipe hubungan sebab-akibat yang didentifikasi. Pertama, membedakan masukan fisik dari manusia, atau proses oleh manusia dan keluarannya terhadap ekosistem hutan atau sistem sosial. Kedua, hubungan sebab-akibat yang berbeda digunakan waktu K\&I diidentifikasi sebagai tegangan-tegangan (atau tekanan-tekanan), yang mempengaruhi keadaan sistem atau berbagai respon dari sistem. Dua tipe klasifikasi tersebut tidak berdiri sendiri. Pengalaman kami telah memperlihatkan bahwa klasifikasi masukan-proses-hasil lebih siap diterima oleh para tim pakar saat membahas berbagai kegiatan manusia.

Stork dkk. (1997) menggambarkan suatu sistem tekanan/respon: sebuah rangkaian kejadian mulai dari intervensi manusia seperti pembalakan hutan yang menimbulkan pengaruh, ${ }^{22}$ fragmentasi habitat, yang kemudian

22 Mereka mengatakan ini sebagai 'mediator' pengaruh perantara. 
mempengaruhi proses, seperti reproduksi yang selanjutnya mempengaruhi keanekaragaman hayati. Dari perspektif ini mereka berpendapat bahwa indikator-indikator tekanan tersebut dapat diterapkan pada awal rangkaian kejadian ini sedangkan indikator-indikator kegiatan atau respon sistem lebih tepat pada bagian akhir.

Beberapa definisi istilah diberikan di bawah ini:

- Masukan dari manusia. Apa yang dimasukkan, diambil atau dioperasikan dalam proses atau sistem tertentu. Contoh: Persentase pendapatan diinvestasikan kembali untuk hutan tersebut.

- Proses oleh manusia. Suatu rangkaian kegiatan manusia atau cara kerja. Contoh: 'Pembalakan direncanakan secara rasional, 'Rimpang yang terlalu besar dihindari'.

- Keluaran. Hasil atau pengaruh yang timbul karena adanya masukan dan proses-proses pada tiga sistem yang dilihat. Contoh: 'Tegakan sisa mengalami regenerasi secara memuaskan'.

- Tekanan. Adalah faktor, kekuatan atau stimulus eksternal yang dialami oleh sebuah sistem. Faktor ini digunakan untuk mengelompokkan sebabsebab perubahan status suatu komponen sistem. Contoh: 'Maksimum lima pohon ditebang per hektar'; 'Pembalakan dilarang pada kemiringan lebih dari $25^{\circ} .{ }^{23}$

Misalnya, Brown dkk. (1997) cenderung memandang indikator genetis suatu lingkungan sebagai ukuran-ukuran respon ekosistem terhadap tekanan eksternal seperti fragmentasi habitat. Mereka berpendapat bahwa

${ }^{23}$ Perhatikan bahwa 'larangan pembalakan' dapat merupakan tekanan terhadap produksi barang dan jasa sedangkan 'ijin pembalakan' dapat menjadi tekanan terhadap ekosistem. 
indikator-indikator respon terhadap tekanan-tekanan ini mempengaruhi ciri-ciri populasi, proses mikro-evolusi dan keragaman genetis.

- Keadaan. Kondisi atau kualitas komponen sistem yang bersangkutan. Klasifikasi ini digunakan kalau tujuannya adalah untuk menggambarkan sebuah kondisi yang diinginkan dari sebuah komponen sistem, terpisah dari kekuatan perubahan apa yang berlangsung dalam sistem. Contoh: 'Masyarakat yang hidupnya bergantung hutan menyadari hak-haknya terhadap sumber daya'.

- Respon. Adalah reaksi sistem terhadap tekanan. Dalam konteks lain respon ditafsirkan secara sempit sebagai respon manusia (terutama kebijakan) terhadap berbagai perubahan keadaan hutan (contoh: Anon. 1993). Dalam konteks sekarang istilah tersebut digunakan untuk mengklasifikasikan respon manusia maupun ekosistem yang berhubungan dengan tekanan atau perubahan keadaan sistem. Beberapa contoh respon mungkin berupa: 'Tumbuhan menjalar seperti Merremia spp. dan Mesoneuron spp. umumnya tidak ada di dalam tegakan' dan 'Berbagai alternatif ekonomi meningkat karena berbagai kegiatan kehutanan'.

\section{Klasifikasi Waktu}

Klasifikasi waktu digunakan untuk mengetahui alokasi kriteria atau indikator dalam suatu periode waktu tertentu, contoh: sebagian besar tingkat pertumbuhan rata-rata merupakan suatu indikator sejarah (masa lalu), volume tegakan total adalah suatu indikator sekarang (saat ini) dan suatu proyeksi tingkat pertumbuhan dapat diprediksi dan merupakan indikator untuk masa depan.

\section{Klasifikasi Menurut Skala Geopolitis}

Klasifikasi ini digunakan untuk mengurutkan kriteria atau indikator menurut tingkat pengaruh primernya terhadap pengelolaan hutan. Misalnya, konversi 
CITES bersifat internasional dalam hal pengaruh geopolitis; definisi 'produksi' atau 'konversi' hutan dalam konteks Indonesia bersifatnasional; pajak lokal, instrumen pelaporan dan pengontrolan/pengawasan dilihat sebagai instrumen regional; dan keputusan yang diambil dalam unit pengelolaan hutan atau populasi sekitar hutan akan berpengaruh lokal.

Pengujian di Jerman memberikan andil besar dalam pengidentifikasian metode-metode ini untuk mengevaluasi K\&I (Palmer 1995, Aneks 5).

\section{Penilaian, Pemantauan dan Panduan: Klarifikasi Istilah}

Karena banyak diterapkan dalam pengelolaan hutan lestari, istilah-istilah penilaian, pemantauan dan panduan sering membingungkan. Konsep-konsep ini saling terkait karena semuanya berkenaan dengan pengelolaan hutan lestari dan ada kesamaan gagasan di antara istilah-istilah tersebut.

Tujuan utama penilaian kelestarian pengelolaan hutan adalah untuk menjawab tiga pertanyaan berikut.

- Apakah pengelolaan hutan memiliki komitmen untuk kelestarian?

- Apakah kondisi hutan dan para penggunanya dapat diterima?

- Apakah respon terhadap intervensi pengelolaan positif?

Untuk menggunakan analogi dokter-pasien, suatupenilaian sebaiknya mencoba dan mencapai suatu diagnosa apakah:

- ada gangguan kesehatan, contoh: kelestarian;

- bagian mana dari tubuh yang mengalami gangguan, seperti dalam kriteria 'Aspek struktur dan keanekaragaman hayati dari integritas ekosistem telah mengalami kerusakan, dan, jika mungkin,

- tingkat kerusakan. 
Penilaian juga dapat memberikan petunjuk mengenai sifat penyakit ('Mata rantai penyerbukan telah terputus'), namun, kami belum melihatnya sebagai ciri yang diperlukan. Kami tidak melihatnya sebagai suatu keharusan dalam sistem penilaian untuk mengusulkan cara-cara penyembuhannya atau pemantauannya. ${ }^{24}$ Fungsi-fungsi ini, jika diinginkan, akan memerlukan modul diagnosa tambahan dan mengarah pada panduan untuk pengelolaan. Dalam sebuah proses sertifikasi umumnya, penilaian kelestarian hanyalah satu dari banyak langkah, seperti yang disajikan dalam Gambar 5.

Kami memandang penilaian dalam konteks pengelolaan hutan lestari sebagai proses di mana informasi tentang pengelolaan hutan dikumpulkan dengan tujuan untuk menetapkan, dalam suatu kerangka kerja harapan-harapan yang jelas, status hutan sekarang dan kemungkinan kecenderungannya di masa depan dalam hal interaksi di antara kehidupan manusia dan hutan, dengan menggunakan kriteria dan indikator tertentu.

Dalam istilah yang lebih konkret, perbedaan antarapenilaian kelestarian dan pemantauan adalah bahwa penilaian bertujuan untuk memudahkan keputusan penilaian di tempat tentang pengelolaan dengan mendefinisikan indikator untuk membandingkan keadaan yang ada dengan sasaran yang sudah didefinisikan sebelumnya, seperti yang disebutkan dalam pengukur 'Tajuk yang dibuka tidak boleh melebihi X persen'. Sebaliknya, dalam prosespemantauan indikator umumnya bersifat lebih netral dan mengikuti prosedur, dan didefinisikan untuk memungkinkan interpretasi terhadap suatu kecen-

${ }^{24}$ Ini jangan dirancukan dengan proses sertifikasi, di mana sah saja untuk mengharapkan pengelolaan untuk menanggapi permintaan dalam melakukan berbagai perbaikan dan memberikan buktinya ketika kunjungan pengawasan berlangsung. 
derungan dalam suatu kurun waktu, berdasarkan pengulangan pengumpulan data (contoh: perubahan persentase luas hutan).

Sebaliknya, panduan biasanya adalah resep untuk tindakan-tindakan yang diperlukan untuk mencapai sasaran tertentu. Panduan ini merupakan indikator penilaian tidak langsung terutama jika indikatornya bersifat memberi resep, seperti 'Tidak boleh ada traktor pembalakan pada lereng yanglebih curam dari $25^{\circ}$. Namun, panduan tidak bersifat implisit dalam suatu indikator preskriptif atau evaluatif (contoh: 'Jenis-jenis dalam suksesi sekunder terhitung kurang dari 10 persen luas bidang dasar'). Dalam kasus ini, untuk menghasilkan panduan yang relevan, asumsi-asumsi yang mendasari perumusan indikator pokok perlu diterjemahkan menjadi resepresep pengelolaan. Interpretasi ini terutama akan diperlukan jika indikator penilaian berorientasi pada respon atau keluaran.

Kami berpendapat bahwa sesungguhnya penyediaan gambaran lengkap dari kondisi yang ada sekarang dalam sebuah sistem penilaian atau pemantauan adalah tidak produktif. Penekanan yang lebih penting sebaiknya diberikan pada pengukuran kecenderungan atau perubahan dalam sistem. Upayaupaya untuk mendeskripsikan keseluruhan sistem justru akan menambah biaya ekstra padahal tidak terlalu diperlukan. 


\section{Gambar 5. Proses Sertifikasi (dari Upton dan Bass 1995).}

Dalam gambar ini penggunaan $K \& I$ hanya terjadi dalam tahap-tahap yang diberi warna

lebih gelap. Proses pengujian dan pemilihan K\&I yang diuraikan dalam panduan ini berlangsung di luar proses ini, atau mungkin sebagai bagian dari kunjungan penapisan.

\begin{tabular}{|c|c|c|}
\hline $\begin{array}{l}\text { Tanggung jawab } \\
\text { lembaga Sertifikasi }\end{array}$ & $\begin{array}{l}\text { Program } \\
\text { Sertifikasi }\end{array}$ & $\begin{array}{c}\text { Tanggung jawab pengelola/ } \\
\text { pemilik hutan }\end{array}$ \\
\hline $\begin{array}{l}\text { wawancara, diskusi, } \\
\text { presentasi, evaluasi } \\
\text { awal kebijakan dan } \\
\text { sasaran (standar) }\end{array}$ & Aplikasi & $\begin{array}{c}\text { menyediakan informasi } \\
\text { dasar, deskripsi lokasi dan } \\
\text { kegiatan pengisian } \\
\text { kuesioner wawancara }\end{array}$ \\
\hline $\begin{array}{l}\text { penilai mengunjungi lokasi, } \\
\text { pemilihan akhir tim audit yang } \\
\text { sesuai kondisi lokal, audit } \\
\text { metodologi dan persiapan } \\
\text { akhir rencana kerja }\end{array}$ & $\begin{array}{l}\text { Kunjungan } \\
\text { Penapisan }\end{array}$ & $\begin{array}{c}\text { pertemuan dengan staf } \\
\text { senior, pemahaman proses } \\
\text { sertifikasi menyediakan } \\
\text { dokumen-dokumen awal } \\
\text { pengelolaan audit logistik }\end{array}$ \\
\hline $\begin{array}{l}\text { memeriksa apakah standar-standar } \\
\text { yang ada memadai dan dipenuhi, } \\
\text { mengidentifikasi prioritas, mengevaluasi } \\
\text { sistem pengelolaan dan menilai } \\
\text { prasyarat-prasyarat sumber dayanya }\end{array}$ & $\begin{array}{l}\text { Tinjauan Dokumen } \\
\text { (pemeriksaan) }\end{array}$ & $\begin{array}{c}\text { menyediakan } \\
\text { dokumentasi yang } \\
\text { rinci }\end{array}$ \\
\hline $\begin{array}{l}\text { melakukan verifikasi indikator utama } \\
\text { dan kecukupan sumber daya, } \\
\text { mensahkan sistem pengelolaan, } \\
\text { wawancara stakeholder eksternal }\end{array}$ & $\begin{array}{l}\text { Penilaian lapang } \\
\text { (pemeriksaan/ } \\
\text { pengesahan) }\end{array}$ & $\begin{array}{l}\text { menyediakan akses ke } \\
\text { lokasi, dokumentasi dan } \\
\text { staf }\end{array}$ \\
\hline $\begin{array}{l}\text { pengesahan teknis } \\
\text { prosedur dan hasil audit }\end{array}$ & $\begin{array}{l}\text { Tinjauan oleh rekan } \\
\text { (keabsahan) }\end{array}$ & $\begin{array}{l}\text { menerima sertifikat dan menerima } \\
\text { syarat-syarat penggunaannya }\end{array}$ \\
\hline $\begin{array}{l}\text { pengesahan teknis } \\
\text { prosedur dan hasil audit }\end{array}$ & Sertifikasi & \\
\hline $\begin{array}{c}\text { mengatur dan } \\
\text { mengimplementasikan rantai } \\
\text { inspeksi pemeliharaan }\end{array}$ & $\begin{array}{l}\text { Pemberian } \\
\text { Label / Nama }\end{array}$ & $\begin{array}{c}\text { berusaha tidak memberi label } \\
\text { tanpa rantai inspeksi } \\
\text { pemeliharaan }\end{array}$ \\
\hline $\begin{array}{c}\text { menilai kelanjutan kepatuhan } \\
\text { dan agar sertifikat tidak disalahgunakan, } \\
\text { menilai kemajuan dalam } \\
\text { 'perkembangan selanjutnya' }\end{array}$ & Tinjauan Berkala & $\begin{array}{l}\text { menyediakan akses untuk } \\
\text { lokasi, dokumentasi dan staf }\end{array}$ \\
\hline
\end{tabular}




\section{Sistem pengelolaan vs. Standar Kinerja}

Konsep kerangka kerja yang disajikan dalam bagian sebelumnya akan dapat diterapkan dengan baik untuk pengembangan sistem penilaian kelestarian berdasarkan:

- K\&I untuk mengevaluasi kehadiran proses atau 'sistem' (seperti yang terdapat dalam sistem pengelolaan lingkungan ${ }^{25}$ ); atau

- K\&I untuk menilai kepatuhan terhadap standar kinerja.

Dasar yang pertama menekankan sifat prosedur dalam sistem pengelolaan dan berusaha memperlihatkan kehadiran dan kualitas sistem-sistem ini. Dasar yang kedua menilai kelestarian berdasarkan set kinerja standar atau sasaran. Namun, kami yakin bahwa kedua pendekatan memiliki keabsahan dan sebaiknya digunakan bersama untuk mencapai efisiensi maksimum. Ini mungkin dilakukan dalan konsep kerangka kerja yang diuraikan, sebagai prosedur maupun sebagai keluaran - atau indikator yang berorientasi sasaran/hasil. Ini ditegaskan oleh hasil pengujian CIFOR; set K\&I yang diusulkan oleh tim di Indonesia, Pantai Gading dan Brasil yang berisi K\&I berdasarkan kinerja dan juga proses. Hasil-hasil ini menunjukkan bahwa kombinasi antara standar proses maupun standar kinerja memang perlu.

Sembilan ciri yang diuraikan dalam Bab 5.3.1 dan perspektif berbeda yang diuraikan dalam Bab 5.3.2 memberikan ide untuk meningkatkan kehematan biaya suatu sistem penilaian. Kehematan biaya seluruhnya akan bergantung pada dua kualitas; isi informasi dari elemen K\&I dan metode yang digunakan untuk mengumpulkan informasi tentang elemen $K \& I$.

${ }^{25}$ Menurut Upton dan Bass (1995), suatu sistem pengelolaan lingkungan didefinisikan sebagai 'struktur organisasi, tanggung jawab, praktek, proses dan sumber daya untuk mengimplementasikan pengelolaan lingkungan'. 


\section{Isi Informasi dan Kehematan Biaya}

Agar hemat biaya, indikator perlu dipilih sedemikian rupa sehingga dapat memberikan informasi tentang perubahan titik-titik kritis dalam sistem. Pemilihan indikator-indikator seperti ini akan menjamin bahwa informasi tentang interaksi sistem yang mempengaruhi titik kritis ini akan tercermin pada perubahan titik itu sendiri. Setelah memilih 'Hal-hal kritis', perhatian berikutnya adalah mendefinisikan indikator-indikator tersebut. Ini dapat dilakukan secara deskriptif, kualitatif atau kuantitatif. Dalam salah satu kasus ini, penting untuk mengetahui apa yang akan diamati atau diukur dan, dalam kasus selanjutnya, ukuran apa yang digunakan. Akhirnya, perlu dipikirkan juga interval waktu tentang informasi apa yang akan diintegrasikan.

Dalam rangka mencapai efisiensi informasi, ada beberapa syarat yang perlu dipenuhi. Beberapa syarat ini telah disebutkan dalam sembilan ciri yang diuraikan dalam Bab 5.3.1. Secara khusus, kehematan biaya dapat ditingkatkan dengan mengembangkan mekanisme-mekanisme untuk saling membagikan informasi secara efektif atau kaitan ganda dari K\&I, bahkan jika mungkin lintas antardisiplin ilmu. Jadi, sebuah indikator biofisik mungkin juga digunakan untuk menentukan pemenuhan suatu kriteria yang berhubungan dengan integritas ekosistem dan juga dengan suatu kriteria sosial. Misalnya, hasil tangkapan ikan di sungai-sungai dalam kawasan pembalakan dapat digunakan sebagai indikator praktek pembalakan (pemeliharaan daerah penyangga di dekat sungai-sungai untuk mencegah kenaikan suhu air dan penimbunan sedimen supaya permukaan sungai tidak meningkat, dll.) dan juga dapat digunakan sebagai suatu indikator dampak ekonomi dan sosial pengelolaan hutan (pendapatan atau substitusi pendapatan, sumber protein hewani, kualitas air). Demikian pula, ciri-ciri populasi dari jenis binatang yang penting mungkin merupakan indikator yang penting untuk 
kriteria ekologis dan juga kriteria sosial (contoh: sebagai sumber makanan untuk masyarakat lokal).

\subsubsection{INTEGRASI INFORMASI DAN K\&I YANG HEMAT BIAYA}

Informasi juga mungkin diintegrasikan tanpa harus memindahkannya ke tingkat hierarki yang lebih tinggi. Ini terjadi misalnya ketika informasi yang terdapat dalam beberapa indikator dipadukan untuk membentuk indikator gabungan yang baru atau nilai indeks gabungan.

Untuk meningkatkan aspek hemat biaya melalui perbaikan isi informasi, seseorang mungkin menanyakan pertanyaan-pertanyaan berikut.

- Sudahkah K\&I berhasil dibatasi untuk bidang-bidang terpenting dalam kelestarian?

- Berapa banyak informasi yang terkandung dalam setiap pokok bahasan $\mathrm{K} \& \mathrm{I}$ ?

- Seberapa hati-hati pendefinisian K\&I telah dilakukan?

- Dapatkah kita mendefinisikan indikator secara lebih baik sehingga dapat mengintegrasikan informasi secara lebih berarti?

- Di mana, dalam sebuah sistem, kita sebaiknya menempatkan suatu indikator dalam rangka meringkas informasi tentang interaksi secara memuaskan?

Perhatikan di sini bahwa ada konflik konsep yang melekat antara keinginan untuk mendapatkan $\mathrm{K} \&$ I yang efisien dan juga saling terkait, dan kebutuhan K\&I spesifik berdasarkan diagnosa. Kami melihat bahwa konflik yang tampak ini tidak kritis. Dalam beberapa kasus kaitannya mungkin lebih diutamakan, dan dalam kasus lain diagnosa yang spesifik mungkin lebih penting. (Lihat 
komentar dalam Bab 5.3.1 mengenai K\&I spesifik berdasarkan diagnosa, dan juga K\&I dalam diskusi 'kaitan' pada bagian M, Formulir 2 dalam Lampiran 8.2)

- Hanya setelah K\&I didefinisikan secara tepat menurut uraian K\&I di atas, isu kehematan biaya dari pengumpulan data perlu dipertimbangkan. Efisiensi biaya tersebut tidak boleh lebih diutamakan daripada desain sistem K\&I yang logis.

(Catatan: Tugas mendefinisikan prosedur lapang akan dilakukan dalam tahap selanjutnya.) 


\section{Tiga Studi Kasus}

Sintesis oleh Phil Macoun berdasarkan laporan proyek

Uraian metode-metode dalam panduan ini bertujuan untuk memandu pengembangan, pengujian dan pemilihan $K \& I$ berdasarkan suatu panduan yang fleksibel namun teliti. Dalam menerapkan metode-metode ini, kami mengharapkan perlunya modifikasi untuk mencerminkan kondisi lokasi masing-masing, dan juga sesuai dengan sasaran khusus pengujian. Bab ini menyajikan tiga contoh yang memperlihatkan penyesuaian metode menurut keadaan spesifik yang ada. Studi kasus yang dibahas adalah:

1. Prakarsa African Timber Organization (ATO) tentang Prinsip, Kriteria dan Indikator untuk Pengelolaan Hutan Lestari di Afrika: Pengujian di Gabon.

2. Pengujian Kriteria dan Indikator Amerika Utara di Boise National Forest, Boise, Idaho.

3. Pengembangan Kriteria dan Indikator untuk Hutan yang Dikelola Masyarakat di Kamerun, Kalimantan Timur dan Brasil.

Dalam semua pengujian ini, garis besar strukturnya disajikan dalam panduan ini, namun setiap pengujian telah menyesuaikan dan mengaplikasikan metode ini dengan cara yang berbeda. Kecuali disebutkan secara khusus, umumnya digunakan 3 Filter dan 2 Formulir (Bab 3.1), dengan beberapa modifikasi. 


\subsection{PRAKARSA AFRICAN TIMBER ORGANIZATION (ATO) TENTANG PRINSIP, KRITERIA DAN INDIKATOR UNTUK PENGELOLAAN HUTAN LESTARI DI AFRIKA: PENGUJIAN DI GABON}

Pengujian terhadap prinsip, kriteria dan indikator untuk pengelolaan hutan lestari dilakukan di Gabon dari 1 April sampai 30 April 1998. Tahap kerja pengujian di lapangan (dua minggu) dilakukan dalam suatu HPH yang luasnya lebih dari 500.000 hektar, milik Compagnie Equatoriale des Bois (CEB) dan terletak di Gabon timur.

Dari tiga studi kasus yang disajikan dalam bab ini, pengujian di Gabon adalah yang paling mendekati panduan metode CIFOR. Oleh karena itu pengujian ini sangat bermanfaat untuk melihat beberapa kelebihan dan kekurangan metode spesifik yang diuraikan dalam panduan ini.

Di lokasi pengujian, sekitar 16.170 penduduk tersebar di 43 desa dan 4 kota dan hampir seluruhnya berada di sekitar atau di dalam lokasi ini. Karena industri kerajinan tangan yang sebelumnya cukup maju sudah tidak ada lagi, kegiatan 'ekonomi' yang saat ini berlangsung hanya untuk kebutuhan sendiri; contohnya, pertanian tradisional, perburuan dan pengumpulan hasil hutan. Perusahaan pembalakan, CEB, telah beroperasi di kawasan ini sejak tahun 1987 dan mempekerjakan sekitar 250 orang di lokasi ini.

Tim pakar terdiri dari 5 anggota, yaitu seorang rimbawan/ekologiwan (juga sebagai pemimpin tim), seorang ekonom, seorang ekologiwan, seorang antropologiwan dan seorang sosiologiwan. Tim pakar didampingi oleh seorang koordinator dari ATO dan kadang menerima masukan 'eksternal' dari pakar lain. Setelah pengujian, tim pakar merasa bahwa jumlah ideal 
anggotanya adalah tiga atau empat dan sebaiknya tidak ada dua pakar dari disiplin ilmu yang sama. ${ }^{26}$ Lebih lanjut, mereka merasa tim ini akan mendapat manfaat dari dukungan keahlian eksternal jangka pendek selama minggu kedua dalam tahap pengujian di lapang.

Selama pengujian ini tim pakar menerapkan metode yang sangat dekat dengan yang dibuat oleh CIFOR, dan hasilnya positif. Beberapa aspek dari metode ini yang mendukung hasil yang positif adalah:

- Pada awal pengujian, disediakan dua hari untuk presentasi metodologi oleh tim pakar CIFOR. Lokakarya Uraian Ringkas ${ }^{27}$ sangat penting untuk dapat melakukan pengujian secara benar. Sebenarnya diperlukan waktu yang lebih banyak untuk persiapan tim pakar bahkan selama pengujian tengah berlangsung karena beberapa hal mendasar dalam metodologi masih belum jelas atau membingungkan para anggota tim.

- Tim pakar menerima dua set dasar, yang berisi 230 butir, yang memenuhi syarat sebagai set awal $K \& I^{28}$. Set yang digunakan adalah: set ATO, yang dianggap relatif tersusun baik dalam hal hierarkinya; set Kribi, yang dihasilkan dari suatu kumpulan enam set, termasuk set ATO.

- Suatu cara pelaksanaan kunjungan lapang (Filter No. 2) yang diterapkan untuk memberikan kesempatan bagi Diskusi Tim Pakar dan mengikuti

${ }^{26}$ Hal ini mengharuskan pemecahan suatu prinsip menjadi beberapa komponen kriteria untuk memberi Bab yang sama kepada masing-masing pakar, sehingga diperlukan pekerjaan tambahan untuk mengumpulkan kembali komponen-komponen tersebut dan menyelesaikan kontradiksi yang ada.

${ }^{27}$ Libat Bab 2.5.3.

${ }^{28}$ Libat Bab 2.3. 
panduan yang disarankan untuk Strukturisasi Interaksi Tim. ${ }^{29}$ Misalnya:

- Perjalanan atau kunjungan lapang sedapat mungkin dilakukan oleh tim multidisiplin ilmu.

- Setiap sore tim pakar dan koordinator mengadakan pertemuan untuk membicarakan masalah-masalah yang dihadapi dan kemajuan yang dicapai selama satu hari itu, serta menyiapkan program kerja untuk hari berikutnya.

- Setiap 3 atau 4 hari, satu hari penuh atau setengah hari dialokasikan untuk pertemuan tim pakar, di mana peserta membagikan informasi tentang kemajuan pekerjaan mereka dan kesulitan-kesulitan yang ditemui.

Tim pakar juga menemui kesulitan-kesulitan dengan beberapa metode CIFOR, dan menyarankan pendekatan alternatif yang mungkin berguna. Mereka merasa bahwa:

- Formulir 2 lebih baik digunakan sebagai alat pengulangan yang dinamis daripada sebagai suatu alat 'statis', yaitu formulirnya diisi sebelum pengujian dan setelahnya.

- Beberapa kerangka kerja dalam formulir (K, L dan M) tidak banyak bermanfaat bagi tim pakar, dan bahkan menimbulkan kebingungan dan membuat formulir ini lebih menjadi beban.

- Formulir 2 memang bermanfaat sebagai alat untuk mencatat dan mengatur data yang dikumpulkan untuk satu butir, tetapi formulir ini tidak memberi petunjuk tentang penyusunan dan strukturisasi butir-butir dalam hierarki. Saat pengujian berlangsung, masalah strukturisasi hierarki ini

${ }^{29}$ Libat Bab 3.3.5. 
paling sulit diatasi oleh anggota tim. Sekitar sembilan sampai sepuluh jam selama hampir tiga hari dihabiskan untuk pembahasan dalam penyusunan set K\&I sebagai keluaran dari Filter No. 2, meskipun banyak pertemuan lainnya di luar jam ini.

Pengujian ditutup dalam suatu lokakarya yang dihadiri oleh sekitar 50 orang dari berbagai bidang keilmuan dan dari banyak negara. Lokakarya ini dilaksanakan sesuai dengan rekomendasi $\mathrm{CIFOR}^{30}$ dan menghasilkan sejumlah penyempurnaan set K\&I akhir yang diusulkan. Dalam lokakarya, ada empat kelompok kerja (pokja) yaitu pokja untuk Kebijakan Umum, pokja untuk Pengelolaan, pokja Ekologi dan pokja Aspek Sosial. Setiap pokja terdiri dari sekitar duapuluh orang, sehingga diskusi yang lebih terbuka bisa terlaksana dan cukup mudah dilakukan oleh pemimpin kelompok. Setiap kelompok dipimpin oleh seorang ketua dan seorang notulis. Hasil-hasil dari seluruh kelompok kemudian dibahas dalam sesi pleno dan hasil hierarkinya diadopsi saat lokakarya.

\subsection{PENGUJIAN DI AMERIKA UTARA TERHADAP KRITERIA DAN INDIKATOR HUTAN LESTARI}

Pengujian tentang Kriteria dan Indikator di Amerika Utara dilakukan dari 8 Juni sampai 10 Juli 1998, yaitu di kawasan Boise National Forest, Idaho, USA. Lokasi pengujian ini luasnya sekitar 4,3 juta akre (1,7 juta hektar) dan terletak di wilayah kerja Forest Service United States Department of Agriculture (USDA) di wilayah barat daya negara bagian Idaho.

${ }^{30}$ Libat Bab 3.4.2 dan 3.4.4. 
Lokasi pengujian Boise ini merupakan suatu studi kasus yang menarik karena kawasan ini mewakili suatu Unit Pengelolaan Hutan (UPH) yang tingkat pengelolaan hutannya sudah canggih. Ciri-ciri kawasan ini adalah:

- Sebagian besar pemilik lahan menganut rencana pengelolaan sumber daya secara komprehensif yang umumnya bertujuan untuk produktivitas dan kesehatan ekologi hutan jangka panjang.

- Kawasan ini memiliki basis data yang komprehensif dan tingkat keterlibatan stakeholdernya tinggi.

- Hutannya mewakili suatu sumber daya bernilai bagi berbagai pihak pengguna, menyediakan penghasilan dari hasil kayu, kesempatan rekreasi alam, kayu bakar dan hasil hutan lain bagi penduduk lokal.

- Kawasan ini juga berfungsi sebagai suatu tempat perlindungan bagi banyak binatang dan tumbuhan, dan melindungi ekosistem serta prosesproses a lami yang mungkin merosot di lahan-lahan di dekatnya.

Para anggota tim pakar dipilih dari berbagai disiplin ilmu dan berasal dari berbagai bagian Amerika Serikat, Kanada dan Meksiko. Tim inti pengujian terdiri dari dua orang ekologiwan, seorang ilmuwan sosial, seorang ekonom, tiga orang manajer hutan, dan seorang ahli genetika hutan. Spesialis tambahan lainnya adalah seorang ahli biokimia karbon, seorang antropologiwan, seorang ekologiwan sistem dan seorang ekologiwan hutan.

Dibandingkan dengan pengujian sebelumnya terhadap metode CIFOR untuk pengembangan, pengujian dan pemilihan K\&I, cakupan pengujian Boise sangat luas. 'Tim pakar' lebih banyak anggotanya dan mencakup disiplin ilmu yang lebih banyak dan mereka bekerja jauh lebih lama di lapang. Mereka juga melakukan pengujian satu langkah lebih lanjut dengan mencoba menerapkan indikator yang dipilih dan mengomentari tingkat kemudahan dalam penggunaannya. 
Set K\&I yang dipilih untuk evaluasi meliputi: 1) K\&I yang berasal dari sintesis CIFOR Tahap I; 2) Panduan Penilaian Dasar CIFOR untuk kesejahteraan manusia; 3) K\&I Canadian Council of Forest Ministers (CCFM) untuk pengelolaan hutan lestari di Kanada; 4) Indikator lokal/regional; termasuk Idaho Forest Practices Act; dan, 5) The Greater Fundy Ecosystem Guidelines, yang dikembangkan untuk Fundy Model Forest.

Sebelum pengujian lapang dimulai di Amerika Utara, diadakan beberapa pertemuan untuk menginformasikan dan memperoleh partisipasi dalam pengujian ini. Pada bulan Maret1998 serangkaian presentasi dilakukan bagi calon mitra kerjasama dan para peserta yang berminat. Para peserta ini mencakup beberapa lembaga, perusahaan dan lainnya yang mungkin bisa memberikan data, menyajikan makalah riset atau menjadi pengamat selama pengujian berlangsung. Selain itu, juga diadakan pertemuan dengan kelompok-kelompok yang mungkin tertarik untuk mengetahui hasil akhir pengujian, tetapi tidak diharapkan untuk berpartisipasi. Akhirnya pertemuan dengan staf negara bagian Idaho dan kongres AS diadakan untuk menyajikan informasi tentang pengujian yang akan dilakukan di Amerika Utara dan apa yang ingin dicapai. Selain itu, para pemimpin pengujian CIFOR bertemu dengan pegawai Boise National Forest dan Boise State University untuk mengatur logistik selama seluruh tim berada di Boise.

Metode yang digunakan umumnya sesuai dengan yang diuraikan dalam buku pegangan ini, tetapi dengan beberapa modifikasi agar lebih cocok dengan konteks di Amerika Utara. Metode ini meliputi tiga langkah yang tersusun dalam empat filter atau tahapan terpisah. Pada setiap tahapan, suatu K\&I tertentu dapat ditolak, digabungkan, atau lolos ke evaluasi yang lebih rinci pada filter selanjutnya. Penggunaan empat filter ini memang lebih banyak 
daripada format yang disarankan dalam Bab 3.1, yaitu tiga filter, tetapi sebenarnya hanya sedikit lebih rinci untuk memperlihatkan kemajuan yang sama.

Tahap 1 dilakukan sesuai dengan metode yang ditentukan untuk Filter 1 (lihat Bab 3.2). Setiap anggota tim diminta untuk membaca sekumpulan informasi yang menyeluruh tentang lokasi penelitian, dan juga berbagai dokumen perencanaan dan evaluasi lokal. Kemudian mereka diberi versi Formulir 1 yang telah dimodifikasi untuk diisi. Seperti Formulir 1 dalam Lampiran 8.1 Formulir ini meminta para pakar untuk mengurutkan (menurut skala 1-5) setiap kriteria dan indikator dibandingkan dengan suatu set parameter. Hasil-hasil Formulir 1 ditabulasi dan dirata-ratakan pada sebuah lembar isian yang kemudian dibagikan kepada semua anggota tim ketika tahap kerja lapang dimulai.

Formulir 1 dimodifikasi dengan cara-cara berikut:

- Sebuah kolom tambahan disediakan untuk menunjukkan apakah setiap elemen set dasar yang dievaluasi adalah Prinsip, Kriteria atau Indikator.

- Kategori yang digunakan untuk mengelompokkan K\&I diganti. Revisi kategori yang digunakan dalam Pengujian Boise Test adalah: Biofisika; Sosial; Perencanaan \& Kebijakan; Pengelolaan pengendalian kerusakan; Pengelolaan pengendalian hasil.

- Sebuah kolom tambahan disediakan untuk meminta para pakar mengurutkan setiap K\&I berdasarkan kesesuaiannya dengan kerangka kerja teoretis.

- Sebuah kotak tambahan disediakan untuk memberikan komentar.

Tahap 2, Kerja lapang awal, berupa lokakarya orientasi selama tiga hari mengenai kondisi sosial, ekonomi dan ekologi lokal, dan juga ringkasan data 
yang tersedia untuk pengujian. Hari ketiga lokakarya digunakan untuk kunjungan lapang, untuk melihat kondisi hutan dan praktek pemanenan di semua lahan yang kepemilikannya berbeda. Kemudian tim bekerja dalam subkelompok dan mendiskusikan hasil tabulasi Formulir 1. Setelah perdebatan berlangsung, ada kriteria dan indikator yang ditolak, digabungkan atau dilanjutkan ke evaluasi selanjutnya yang lebih rinci. Proses ini adalah versi yang lebih mendalam dari 'Diskusi Tim Awal', yang diuraikan dalam langkah pertama yaitu Filter 2 .

Di antara set kriteria dan indikator yang diuji, terminologinya tidak konsisten. Untuk menguji elemen yang sama dalam set indikator yang berbeda (yaitu Tahap I CIFOR dan CCFM), para anggota menggunakan definisi Prinsip, Kriteria, dan Indikator yang diberikan oleh Tropenbos (1997). Kriteria dan indikator dikelompokkan kembali ke dalam tiga prinsip utama, mengikuti definisi Tropenbos. Prinsip-prinsip ini adalah (1) memelihara integritas lingkungan, (2) hasil dan kualitas kekayaan hutan bersifat lestari, dan (3) masyarakat menerima tanggung jawab untuk pengelolaan sumber daya.

Pada Tahap 3, Evaluasi lapang, para anggota bekerja dengan bahan-bahan pustaka, para pakar lain dan dalam kelompok diskusi untuk mengritik atau menyempurnakan dasar-dasar teoretis untuk setiap kriteria atau indikator. Dalam beberapa kasus tahap ini memerlukan kontak langsung dengan para pakar di kawasan lokal atau menghubungi orang lain melalui telepon atau e-mail. Untuk setiap indikator mereka juga mencoba untuk menggunakan data dari Boise Study Area untuk menilai kepraktisannya. Para anggota tim juga berbicara dengan nara sumber lokal untuk mengetahui pendapat mereka tentang nilai suatu indikator. Tahap ini dapat dianggap sebagai latihan-latihan lapang yang direkomendasikan sebagai bagian kedua Filter 2. 
Untuk setiap indikator yang diuji, para anggota tim mengisi Formulir 2 (Lampiran 8.2) yang telah dimodifikasi. Modifikasi ini tidak mengubah isi informasi yang dikumpulkan untuk setiap kriteria dan indikator, tetapi untuk membantu memfokuskan informasi ini sehingga jauh lebih bermanfaat bagi tim pengujian.

Dalam Tahap 4 diadakan lokakarya setelah kerja lapang. Lokakarya ini berlangsung selama dua hari, yang dihadiri 60 peserta baru dari lembaga dengan latar belakang disiplin ilmu yang berbeda. Selama lokakarya ini, kelompok kerja membahas usulan-usulan yang disiapkan oleh tim yang bersangkutan. Lokakarya ini menyediakan kesempatan bagi para anggota tim untuk mendapatkan komentar dari rekan lainnya, dan juga untuk mendapatkan tanggapan pertama tentang K\&I yang diusulkan dan tingkat penerapannya yang lebih luas.

Beberapa masalah yang dialami oleh tim dalam usahanya untuk menciptakan suatu set K\&I yang relevan untuk konteks lokal di Boise, Idaho, mungkin juga dapat dijadikan masukan bagi tim lain yang berusaha untuk menyesuaikan set K\&I. Sampai tahapan ini isu-isu yang muncul dalam kaitannya dengan K\&I yang berbeda untuk disiplin ilmu yang berbeda diuraikan sebagai berikut.

K\&I Ekologi:

- Pengukuran variabel ekologi secara praktis akan menghabiskan banyak biaya dan waktu.

- Banyak set indikator yang tidak memberikan dukungan atau penjelasan yang mendukung konsep. Alasan teoretis untuk pemilihan indikator sering terlalu singkat atau tidak ada.

- Pengukuran-pengukuran dalam set CCFM dan CIFOR terlalu 
mengandalkan data yang sudah tersedia, sehingga datanya harus dikembangkan supaya sesuai. Oleh karena itu tingkat manfaat indikator menjadi berkurang.

- Indikator ekologi CIFOR cenderung lebih sesuai untuk hutan tropis dan tidak terlalu tepat untuk lokasi Boise yang beriklim sedang.

K\&I Ekonomi:

- K\&I CIFOR dan PPD-CIFOR (versi awal Perangkat No. 5) tidak mencakup indikator ekonomi yang jelas selain beberapa pertimbangan keadilan. Sebuah makalah kerja CIFOR oleh Ruitenbeek dan Carter (1998) yang membahas K\&I dari sudut pandang ekonomi digunakan sebagai dokumen sumber.

- Hampir seluruh K\&I CCFM fokusnya adalah parameter ekonomi nasional dan sulit untuk menerapkannya pada tingkat UPH.

- Anggota tim merasa bahwa set yang diuji sangat terbatas, karena sifatnya diagnostik dan fokusnya lebih ke struktur ekonomi dengan sedikit aspek dinamis. Hubungan dengan kelestarian kebanyakan berada di urutan kedua.

K\&I Pengelolaan:

Indikator pengelolaan sasarannya hanya kawasan yang termasuk dalam program pengelolaan hutan, dan fokusnya cenderung pada pengelolaan pohonpohon. Dalam konteks pengujian di Amerika Utara hal ini berarti konsep teori pengelolaan hutan hanya diterapkan pada kira-kira 25\% dari seluruh kawasan seluruhnya, karena hanya 25\% luas kawasan pengujian yang bisa diambil hasilnya. Tim pakar mengidentifikasi perlunya indikator yang dapat diterapkan untuk seluruh kawasan atau ekosistem yang diteliti. Untuk itu definisi pengelolaan perlu diperluas dengan memasukkan kegiatan-kegiatan 
seperti: tidak ada pengelolaan, restorasi terestrial dan perairan, penebangan hutan nontradisional, perencanaan untuk fungsi ekologi dan lainnya.

K\&I Sosial:

- Perbedaan antara negara maju dan negara berkembang dalam pengujian di Amerika Utara dan pengujian K\&I PPD-CIFOR yang dilakukan sebelumnya membuat indikator yang dihasilkan tidak bisa diterapkan secara tepat. Keadaan yang kontras ini dapat dijelaskan sebagai perbedaan antara masyarakat yang hidup di dalam hutan atau masyarakat yang tergantung pada hutan dan masyarakat yang tinggal di suatu kawasan berhutan.

- Dalam konteks Amerika Utara landasan hukum dan perundangundangan yang sangat luas melindungi berbagai hak kepemilikan dan perjanjian yang lebih bervariasi daripada di negara sedang berkembang. Hasilnya indikator ini relatif mudah untuk dinilai, tetapi tidak berguna untuk mengukur kepuasan masyarakat terhadap struktur hukum/ perundang-undangan.

- Metode PPD-CIFOR kebanyakan bersumber dari antropologi dan tidak dirancang untuk memanfaatkan sebanyak mungkin sumber-sumber data yang ada di Amerika Utara. Oleh karena itu metode ini hanya berguna di tempat pengujian yang relatif sempit atau sebagai cara awal penyempurnaan metode.

Secara umum masalah-masalah utama yang ditemukan dalam set K\&I yang diuji adalah:

- Set indikator yang diuji dikembangkan pada tingkat nasional, dan tidak mudah diterapkan pada tingkat pengelolaan hutan;

- Baik set CCFM maupun CIFOR Tahap 1 tidak memberikan nilai-nilai 
sasaran yang berguna ('norma' atau nilai ambang batas) untuk indikatornya. Agar lebih berguna, indikator ini perlu dikaitkan dengan suatu nilai sasaran yang diacu;

- Sering ada kerancuan atau tumpang tindih antara set-set indikator dalam hal definisi Prinsip, Kriteria dan Indikator;

- Set indikator yang diuji secara umum kurang didokumentasikan dan dijadikan bahan acuan.

- Set indikator tidak menjawab isu-isu operasional yang berkaitan dengan penerapannya. Misalnya, isu-isu biaya, tingkat kemudahan untuk pengulangan, pengelolaan data dan pengawasan kualitas; dan

- Akhirnya, para pakar merasakan sangat sulit bekerja dalam tim lintas disiplin ilmu karena masih belum ada dasar teoretis yang diterima untuk menggabungkan indikator ekologi, sosial dan ekonomi. Sebuah makalah oleh Hoekstra dkk., (1998) diajukan sebagai dasar teoretis untuk penggabungan ini.

\subsection{PENGUJIAN DAN PENGEMBANGAN KRITERIA DAN INDIKATOR UNTUK HUTAN YANG DIKELOLA MASYARAKAT}

Pengujian K\&I untuk hutan yang dikelola masyarakat (community managed forests - CMF) dilakukan antara bulan Maret 1997 dan Februari 1998 di tiga lokasi pengujian: Central Province, Kamerun; Kalimantan Barat, Indonesia; Para, Brasil. Fokus riset CIFOR sebelumnya untuk pengembangan K\&I adalah kelestarian produksi kayu pada Tingkat Unit Pengelolaan Hutan di kawasan hutan alami. Dalam pengujian K\&I untuk CMF sasarannya diperluas sampai pengujian dan pengembangan $K \& I$ untuk kelestarian tipe penge- 
lolaan hutan lainnya, termasuk perkebunan dan pengelolaan hutan oleh masyarakat.

Setiap pengujian berlangsung satu bulan dan dikerjakan oleh tim lintas disiplin ilmu yang terdiri dari seorang ilmuwan sosial, seorang ekologiwan dan seorang spesialis pengelolaan hutan, dan juga berkonsultasi dengan masyarakat hutan lokal. Sesuai dengan berbagai disiplin limu ini set K\&I yang dihasilkan dibagi menjadi tiga kategori: sosial-ekonomi, pengelolaan hutan dan ekologi. Partisipasi masyarakat terus diupayakan selama pengujian ini yaitu dengan menggunakan teknik Participatory Rural Appraisal (PRA).

Sasaran pengujian adalah untuk:

- Mengidentifikasi K\&I yang dapat digunakan oleh berbagai kelompok pemerhati hutan untuk menilai kelestarian sumber daya hutan di lokasilokasi pengujian;

- Mengetahui sejauh mana K\&I yang dihasilkan relevan untuk lokasi geografis lainnya yang bukan lokasi pengujian; dan

- Menilai sumber daya apa saja yang akan diperlukan oleh para calon pengguna agar dapat menerapkan K\&I yang dihasilkan. Misalnya, dana bantuan, pengetahuan, ketrampilan dan teknologi.

Selama pengujian ada beberapa aspek berbeda yang juga mendapat sorotan, yaitu dalam kaitannya dengan metode-metode yang dianjurkan oleh CIFOR untuk pengembangan, pengujian dan pemilihan K\&I. Beberapa kekuatan dan keterbatasan umum metode CIFOR juga ditemukan. Pengujian ini juga membantu mengungkapkan kesesuaian metode ini untuk mendorong partisipasi masyarakat dan menyaring informasi yang dapat diterapkan secara umum di berbagai lokasi. 


\section{Kekuatan dan Keterbatasan Umum}

Hal-hal yang dibahas berikut ini adalah kekuatan dan kelemahan metode CIFOR yang diuraikan dalam panduan ini, dan beberapa di antaranya berhubungan dengan cara-cara metode ini diterapkan dalam pengujian K\&I untuk hutan yang dikelola masyarakat.

Kekuatan metode ini adalah:

- Fokus pada kunjungan lapang. Hampir seluruh penguji memiliki pengalaman yang luas di bidang kehutanan masyarakat atau pembangunan terpadu daerah pedesaan di kawasan yang berhutan. Namun, setelah mereka berkonsultasi dengan para penghuni hutan dan mengunjungi rumah, kebun dan hutan mereka, semua mengakui perlunya menyesuaikan pemikiran awal mereka tentang hal-hal yang dianggap paling relevan untuk penerapan $\mathrm{K} \& \mathrm{I}$ di hutan yang dikelola masyarakat. Hal ini menegaskan pentingnya kunjungan lapang yang merupakan faktor terpenting dalam metode yang direkomendasikan.

- Partisipasi masyarakat. Partisipasi masyarakat hutan sangat membantu kelompok stakeholder yang berbeda untuk lebih mengerti saling keterkaitan antara gagasan dan kepentingan masing-masing stakeholder.

Keterbatasan metode ini adalah:

- Kemampuan Hierarki Tropenbos mengenai Prinsip, Kriteria, Indikator dan Pengukur untuk mewakili kenyataan sebenarnya di lapang ternyata sangat terbatas, karena pendekatannya tidak fleksibel dalam hal menempatkan isu-isu pada suatu tingkat hierarkis tunggal, padahal suatu isu dapat dimunculkan dalam bentuk yang berbeda pada tingkat hierarkis yang berbeda. Pemisahan isu-isu yang berkaitan dengan ekologi, pengelolaan hutan dan sosial membuatnya sulit untuk mengidentifikasi hubungan di antara kategori-ketegori ini. 
Dalam konteks Hutan yang Dikelola Masyarakat, pemilahan beberapa isu mungkin bisa disajikan lebih baik, menggunakan $\mathrm{K} \& \mathrm{I}$ lintas antar disiplin ilmu yang kompleks, daripada dipisah menjadi 3 set disiplin ilmu yang spesifik. Contohnya, untuk memantau bagaimana perubahan nilai ekonomi hutan mempengaruhi kebiasaan dan tingkah laku masyarakat terhadap konservasi, kami perlu memantau variabel sosial-ekonomi, ekologi dan aspek-aspek manajerial. Namun yang paling perlu dipantau adalah hubungan antara tipe variabel ini dan keluarannya.

- Selama pengujian-pengujian ini berlangsung ada isu-isu yang muncul dan mengungkapkan pentingnya pemilihan tim 'pakar' secara hati-hati untuk proses kegiatan yang melibatkan berbagai disiplin ilmu ${ }^{31}$. Misalnya, dalam pengujian di Brasil dan Kamerun beberapa anggota tim memilih bekerja sendiri untuk jangka waktu yang cukup lama, sehingga menghambat penggabungan subset yang dibuat dalam pengujian-pengujian ini. Mereka berpendapat bahwa pemisahan isu-isu menurut disiplin ilmu justru menghalangi penggabungan usaha-usaha oleh disiplin ilmu yang berbeda secara efektif.

Ukuran tim pemilihan yang relatif kecil kemungkinan juga ikut menyulitkan mereka dalam menggabungkan disiplin ilmu yang berbeda. Dalam Bab 2.5 kami menyarankan bahwa 'tim yang beranggotakan lima atau enam orang merupakan 'ukuran yang lebih baik 'untuk diskusi', dan lebih banyak diskusi di antara para penguji dapat lebih membantu menjelaskan cara-cara yang lebih baik bagi disiplin ilmu yang berbeda untuk saling berinteraksi. Dalam pengujian-pengujian ini pemimpin tim juga perlu terus mendorong partisipasi dan kerjasama semua anggota tim dalam menerapkan pendekatan antardisiplin ilmu selama pengujian.

31 Untuk tinjauan dari aspek-aspek penting pemilihan dan komposisi tim lihat Bab 2.5.1. 
Faktor lain yang disebutkan oleh anggota tim adalah jangka waktu yang relatif singkat untuk melakukan pengujian. Jangka waktu yang lebih lama dapat memberikan lebih banyak waktu untuk diskusi antara para penguji, yang akan menghasilkan intergrasi antardisiplin ilmu secara lebih efektif.

- Selama pengujian, tim juga dihadapkan pada set dasar K\&I yang berisi banyak K\&I yang semula diusulkan untuk pengelolaan hutan industri, dan kemudian diminta untuk memilih K\&I untuk hutan yang dikelola masyarakat. Dalam banyak kasus, pengujian ini mendatangkan bias ke dalam set akhir yang terkumpul. Tim menduga bahwa K\&I yang lebih sedikit untuk pengelolaan hutan komersial mungkin telah dimasukkan dalam Set K\&I yang dirumuskan selama pengujian, set dasarnya berbeda, atau tidak memiliki set dasar, yang diuji sebagai bagian dari tahap ini. Oleh karena itu, pengujian-pengujian ini menjelaskan pentingnya pemilihan set awal K\&I yang sesuai.

- Sementara komentar oleh sesama pakar yang disampaikan dalam lokakarya akhir memang penting, pengujian K\&I untuk hutan yang dikelola masyarakat menunjukkan bahwa rekomendasi yang diberikan perlu diterima secara hati-hati karena banyak di antara peserta yang tidak terlalu mengenal lokasi pengujian ini. Selama pengujian, dalam lokakarya akhir ada kesempatan untuk mengungkapkan hipotesis baru yang belum diuji untuk diajukan menjadi bagian Set K\&I yang telah diuji lapang. Tujuannya adalah untuk menghilangkan hipotesis yang tidak valid. Hal ini membuat lokakarya tidak konsisten dengan tujuan pembuatan usulan Set K\&I yang lebih relevan dan hemat biaya. Hipotesis yang tidak diuji ini mungkin bisa kontra-produktif, dan bahkan membuat set yang akhirnya menjadi tidak relevan atau tidak hemat biaya untuk berbagai lokasi. 
- Salah satu dari sasaran awal K\&I untuk pengujian di hutan yang dikelola masyarakat adalah untuk mengevaluasi indikator dan pengukur yang dikembangkan berdasarkan kriteria 'kemudahan penggunaan' dan ‘biaya penerapan'. Sasaran ini tidak dapat dicapai secara memuaskan dalam kerangka waktu proses pengujian karena ciri-ciri ini harus dievaluasi secara terpisah untuk setiap calon kelompok pengguna. Dengan demikian, kerangka waktu selama satu bulan terlalu singkat untuk pengujian indikator dan pengukur secara benar untuk hutan yang dikelola masyarakat.

\section{Partisipasi Masyarakat}

Selama proses pengujian lapang, para anggota masyarakat didorong untuk aktif menyumbangkan ide-ide mereka. Namun, selama proses-proses berikutnya yang mencapai puncaknya pada lokakarya akhir, anggota masyarakat semakin kurang dilibatkan dalam proses pengujian. Akibatnya isi dari Set K\&I yang dikembangkan akhirnya hanya ditetapkan oleh tim pakar meskipun ada persetujuan meningkatkan partisipasi masyarakat secara lebih interaktif. Oleh karena itu, set akhir mungkin tidak sepenuhnya sesuai dengan definisi masyarakat tentang indikator yang seharusnya atau yang disepakati bersama.

Secara umum masyarakat desa berpartisipasi dalam memberi informasi. Peserta yang paling aktif dan vokal cenderung dari anggota masyarakat yang lebih kaya dan berpengaruh secara politis. Beberapa dari penghalang terhadap partisipasi masyarakat yang lebih efektif adalah:

- perbedaan yang jelas di pihak penguji dalam hal menerapkan pendekatan mereka untuk memperoleh informasi dan dalam menerapkan pengetahuan lokal.

- Kendala bahasa di lokasi pengujian Kamerun dan Indonesia, karena mayoritas penduduk lokal hanya berbicara dalam bahasa sukunya. 
Ada kecenderungan bahwa pihak yang bukan anggota masyarakat ikut mengevaluasi kontribusi anggota masyarakat menurut standar mereka sendiri. Kecenderungan ini khususnya jelas terlihat dalam lokakarya ketika para profesional sedang membahas K\&I dengan anggota masyarakat. Peserta lokakarya cenderung untuk: sibuk berdebat sampai pembahasan yang bersifat akademis melampaui tingkat pemahaman masyarakat yang menjadi peserta lokakarya; secara substansial meragukan akan validitas dan kegunaan pengetahuan lokal; terlalu khawatir untuk membiarkan orang lokal menguasai diskusi karena takut bahwa pertanyaan-pertanyaan yang penting tidak dibahas secara memadai.

Lebih lanjut, dalam lokakarya penutup masyarakat memiliki kemampuan dan pengetahuan yang berbeda. Karena bahasa dan wawasan yang berbeda, tidak semua peserta dapat dengan mudah saling mengerti satu sama lain. Secara umum, peserta yang vokal dan lebih tegas cenderung lebih berpengaruh dalam perdebatan.

\section{Generalisasi untuk Lokasi yang Berbeda}

Usaha untuk mengidentifikasi prinsip-prinsip umum yang dapat diterapkan di berbagai lokasi terbukti sangat sulit. Tiga Set K\&I yang digabungkan dari pengujian yang berbeda jelas berbeda memperlihatkan perbedaan isu-isu yang ditangani dan distribusi penekanannya dalam masing-masing isu. Mungkin penyebabnya adalah:

- Perbedaan spesialisasi di antara para pakar;

- Perbedaan prioritas perhatian lokal;

- Variasi dalam hal kemudahan akses informasi yang relevan; dan

- Pengalaman praktis. Misalnya, tidak ada pakar anggota tim yang memiliki keahlian teknis penyadapan karet, sehingga pengertian mereka tentang 
praktek penyadapan karet yang dianggap baik terbatas dalam lingkup pengetahuan lokal. Di lokasi lainnya perbedaan pengalaman praktis ini juga sangat bervariasi.

Faktor lain yang menyulitkan untuk membandingkan hasil-hasil dari tiga pengujian adalah variasi penggunaan kata definisi. Misalnya, ketidakkonsistenan dalam mendefinisikan Prinsip, Kriteria, Indikator dan Pengukur menyulitkan untuk mengidentifikasi K\&I umum. Demikain juga untuk mengidentifikasi K\&I yang umum untuk lebih dari satu lokasi. K\&I disaring menurut kemiripan kata-kata kunci dan persamaan konseptual; sampai sejauh mana kata-kata yang berbeda dalam konteks yang serupa, atau katakata yang sama dalam konteks yang berbeda, dianggap memiliki pengertian yang sama, masih merupakan pertanyaan yang belum terjawab. Misalnya, Indikator yang berisi kata-kata seperti 'dilarang', 'larangan', 'tidak sah', 'kuasa', 'terlarang', tidak terlalu jelas menunjukkan distribusi kekuasaan, kecuali jika posisi kata-kata ini dalam K\&I yang kompleks jelas menunjukkan kekuasaan siapa yang menjadi fokus.

Secara umum, hasil-hasil pengujian K\&I untuk hutan yang dikelola masyarakat dan pengelolaan hutan untuk kayu komersial menunjukkan bahwa Prinsip dan Kriteria, sebagai suatu kumpulan kebenaran fundamental yang luas, memiliki relevansi universal. Indikator dan Pengukur yang lebih rinci, yang merupakan perangkat penilaian yang lebih praktis untuk mengevaluasi sejauh mana proses dan metode yang diadaptasi sesuai dengan berbagai peluang dan kendala kondisi lokal, jauh lebih bervariasi di antara lokasi yang berbeda. Temuan-temuan ini sesuai dengan hasil temuan Prabhu dkk. (1996). 


\section{LAPORAN-LAPORAN PROYEK}

\section{PENGUJIAN ATO DI GABON}

Nasi, R. 1998. Initiative of the African Timber Organization on principles, criteria and indicators (PCIs) for sustainable forest management in Africa. Test on PCIs in Gabon. CIFOR Draft Report. CIFOR, Bogor, Indonesia.

\section{PENGUJIAN DI AMERIKA UTARA}

Woodley, S., Alward, G., Guiterrez, L.I., Hoekstra, T., Holt, B., Livingston, L. Loo, J., Skibicki, A., Williams, C., Wright, P. 1999a. North American test of criteria and indicators of sustainable forestry. USAID/USFS/CIFOR Report - Volume 1. Washington, DC.

Woodley, S., Alward, G., Guiterrez, L.I., Hoekstra, T., Holt, B., Livingston, L. Loo, J., Skibicki, A., Williams, C., Wright, P. 1999b. North American test of criteria and indicators of sustainable forestry. USAID/USFS/CIFOR Report - Volume 2. Washington, DC.

\section{HUTAN YANG DIKELOLA MASYARAKAT}

Burford de Oliveira, N., Shiembo, P.N., Tiani, A.M. dan Vabi, M. 1998. Developing and testing criteria and indicators for the sustainability of community managed forests in the SOLIDAM zone, Central Province, Cameroon. CIFOR Draft Report. CIFOR, Bogor, Indonesia.

Burford de Oliveira, N. 1999. Community participation in developing and applying criteria and indicators of sustainable and equitable forest management. CIFOR Draft Report. CIFOR, Bogor, Indonesia.

Burford de Oliveira, N. bersama Ritchie, B., McDougall, C., Hartanto, H. dan Setyawati, T. 1999. Developing criteria and indicators of community 
managed forests, as assessment and learning tools: objectives, methodologies, results. CIFOR Draft Report. CIFOR, Bogor, Indonesia.

Maryani, R., Sunito, S., Hatta, G., Burford de Oliviera, N. 1998. Developing criteria and indicators for community managed forests. Indonesian test sites: Bedigong and Darok villages, Sanggau-West Kalimantan. CIFOR Report. CIFOR, Bogor, Indonesia. 


\section{Pustaka dan Bahan Bacaan Lanjutan}

Anon. 1993. OECD Core Set of Indicators for Environmental Performance Review. Environment Monograph No. 83. OECD, Paris.

Attiwill, P.M. 1994. The disturbance of forest ecosystems: the ecological basis for conservative management. Forest Ecology and Management 63: 247-300.

Boyle, T.J.B., M. Lawes, N. Manokaran, R. Prabhu, J. Ghazoul, S. Sastrapradja, H.-C. Thang, V. Dale, H. Eeley, B. Finegan, J. Soberon dan N.E. Stork. Criteria and Indicators for Assessing the Sustainability of Forest Management: A Practical Approach to Assessment of Biodiversity. CIFOR, Bogor.

Brown, A.H.D., A.G. Young, J.J. Burdon, L. Christidis, G. Clarke, D. Coates dan W. Sherwin. 1997. Genetic Indicators for State of the Environment Reporting. Report of a workshop on genetic indicators for state of the environment reporting held at the centre for plant biodiversity research, CSIRO Plant Industry, 9-13 April 1997. CSIRO, Canberra.

Colfer, C.J. Pierce. 1995. Who Counts Most in Sustainable Forest Management? CIFOR Working Paper No. 7. CIFOR, Bogor.

Colfer, C.J. Pierce dan R.L. Wadley. 1996. Assessing "Participation" in Forest Management: Workable Methods and Unworkable Assumptions. CIFOR Working Paper No. 12.

Colfer, C.J. Pierce dengan R. Prabhu dan E. Wollenberg. 1995. Principles, Criteria and Indicators: Applying Ockam's Razor to the People - Forest Link. CIFOR Working Paper No. 8. CIFOR, Bogor. 
Colfer, C.J. Pierce, R.L. Wadley, E. Harwell dan R. Prabhu. 1997. Inter-generational Access to Resources: Developing Criteria and Indicators. CIFOR Working Paper No. 18. CIFOR, Bogor.

Colfer, C.J. Pierce, J. Woelfel, R.L. Wadley dan E. Harwell 1996. Assessing People's Perceptions of Forests in Danau Sentarum Wildlife Reserve. CIFOR Working Paper No. 13. CIFOR, Bogor.

Constanza, R. 1992. Ecological economic issues and considerations in indicator development, selection and use: Toward an operational definition of ecosystem health. Dalam: D.H. McKenzie, D.E. Hyatt dan J.E. McDonald (eds.), Ecological Indicators, Volume 2, h. 1491-1502. Elsevier Applied Science, London.

Gentile, J.H. dan M.W. Slimak. 1992. Endpoints and indicators in ecological risk assessments. Dalam: D.H. McKenzie, D.E. Hyatt dan J.E. McDonald (eds.), Ecological Indicators, Volume 2, h. 1385-1397. Elsevier Applied Science, London.

ITTO (International Tropical Timber Organization). 1991. Criteria for the Measurement of Sustainable Tropical Forest Management. ITTO, Yokohama.

Lammerts van Bueren, E.M. dan E. Blom. 1997. Hierarchical Framework for the Formulation of Sustainable Forest Management Standards: Principles, Criteria and Indicators. The Tropenbos Foundation, Leiden.

Landres, P.B. 1992. Ecological indicators: Panacea or liability? Dalam: D.H. McKenzie, D.E. Hyatt dan J.E. McDonald (eds.), Ecological Indicators, Volume 2, h. 1295-1319. Elsevier Applied Science, London.

Liang, T.Y. 1994. The basic entity model: A fundamental theoretical model of information and information processing. Information and Management 30: $647-661$. 
Mengin-Lecreulx, P. dengan A. Anvo, C. Huttel, H. van Haaften dan N'Guessan K. Anatole. 1995. Final Report: Test Côte d'Ivoire June 2-30, 1995. CIFOR Project on Testing Criteria and Indicators for Sustainable Mangement of Forests. CIFOR, Bogor (English translation by Guy Ferlin).

Ostrom, E. 1994. Neither Market nor State: Governance of Common-pool Resources in the Twenty-first Century. International Food Policy Research Institute, Washington, DC.

Palmer, J. dengan P. Boateng, Lukito Daryadi, E. Panitz dan P. Rosenberg 1994. Final Report, Test Germany November 12-28, 1994. CIFOR Project on Testing Criteria and Indicators for Sustainable Management of Forests. CIFOR, Bogor.

Schmutzenhofer, H. 1992. IUFRO's birthday. IUFRO News 21: 3.

Stork, N.E., T.J.B. Boyle, V. Dale, H. Eeley, B. Finegan, M. Lawes, N. Maokaran, R. Prabhu dan J. Soberon. 1997. Criteria and Indicators for Assessing the Sustainability of Forest Management: Conservation of Biodiversity. CIFOR Working Paper No. 17. CIFOR, Bogor.

Schneider, E.D. 1992. Monitoring for ecological integrity: The state of the art. Dalam: D.H. McKenzie, D.E. Hyatt dan J.E. McDonald (eds.), Ecological Indicators, Volume 2, h. 1403-1419. Elsevier Applied Science, London.

Upton, C. dan S. Bass 1995. The Forest Certification Handbook. Earthscan Publications, London.

Wiersum, K.F. 1995. 200 years of sustainability in forestry: Lessons from history. Environmental Management 19: 321-329.

Wollenberg E. dan C.J. Pierce Colfer 1996. Social sustainability in the forest. ITTO Newsletter 6(2): 9-11. 
World Commission on Environment and Development. 1988. Our Common Future.

Oxford University Press, Oxford (Commission report chaired by Gro Brundtland). 


\section{Lampiran}

- Contoh Formulir 1

- Contoh Formulir 2

- Perangkat Penilaian K\&I Sosial

- Contoh Cara Menyusun Tabel dan Menyajikan Daftar Akhir $\mathrm{K} \& \mathrm{I}$

- Glosari 


\subsection{Contoh Formulir 1}

\section{Formulir 1:}

\begin{tabular}{|c|c|c|c|c|c|c|c|}
\hline 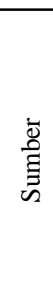 & 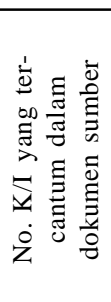 & 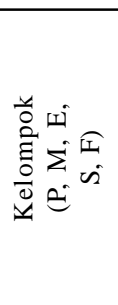 & 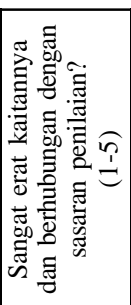 & 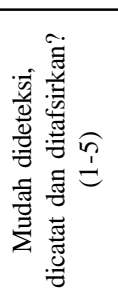 & 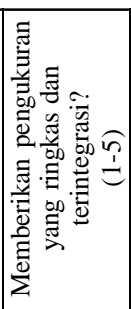 & 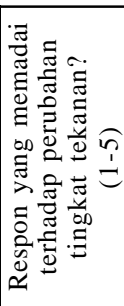 & 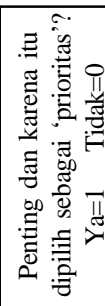 \\
\hline 1 & 2 & 3 & 4 & 5 & 6 & 7 & 8 \\
\hline & & & & & & & \\
\hline
\end{tabular}

Keterangan:

P : Kerangka kerja kebijakan, perencanaan dan legal

$\mathrm{S}$ : Dampak sosial

M : Kegiatan kehutanan, produksi barang dan jasa

E : Dampak ekologis

F : Aspek keuangan/finansial dan ekonomi 


\section{Lanjutan, Contoh Formulir 1}

Formulir 1: Untuk Ujicoba Kamerun. Isilah formulir ini sebelum 28 Oktober.

\begin{tabular}{|c|c|c|c|c|c|c|c|}
\hline $\begin{array}{l}\overline{\mathbf{D}} \\
\text { है } \\
\text { है }\end{array}$ & 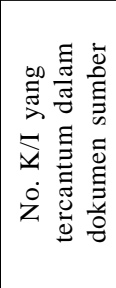 & 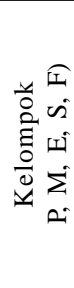 & 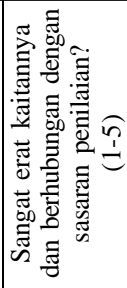 & 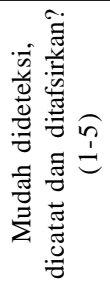 & 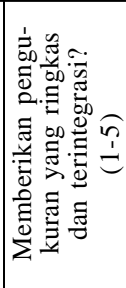 & 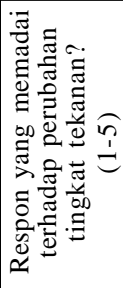 & 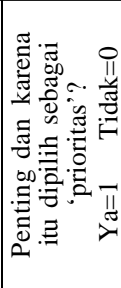 \\
\hline 1 & 2 & 3 & 4 & 5 & 6 & 7 & 8 \\
\hline $1(=A T O)$ & B.2.3 & $\mathrm{P}$ & 4 & 1 & 4 & 2 & 1 \\
\hline 1 & B. 3 & $\mathrm{P}$ & 5 & 2 & 2 & 4 & 1 \\
\hline 1 & B. 3.1 & $\mathrm{P}$ & 5 & 4 & 3 & 4 & 1 \\
\hline 1 & B. 3.2 & S & 3 & 3 & 1 & 2 & 1 \\
\hline 1 & K. 1 & $\mathrm{P}$ & 5 & 3 & 5 & 2 & 1 \\
\hline 1 & K.1.1 & M & 5 & 4 & 4 & 5 & 1 \\
\hline 1 & K.1.2 & $\mathrm{P}$ & 5 & 5 & 1 & 4 & 1 \\
\hline 1 & K.1.3 & M & 3 & 3 & 2 & 1 & 1 \\
\hline 1 & K. 1.4 & M & 4 & 4 & 2 & 1 & 1 \\
\hline 1 & K. 2 & M & 5 & 2 & 3 & 1 & 1 \\
\hline 1 & K.1 & M & & & & & \\
\hline 1 & K.1.1 & M & 4 & 2 & 4 & 3 & 0 \\
\hline 1 & K.1.2 & M & 5 & 4 & 2 & 2 & 0 \\
\hline 1 & K.1.2* & M & 5 & 4 & 4 & 4 & 1 \\
\hline 1 & K.1.2.1 & $\mathrm{E}$ & 4 & 2 & 4 & 2 & 1 \\
\hline 1 & K.1.2.2 & E & 5 & 4 & 3 & 1 & 1 \\
\hline 1 & K.1.2.3 & M & 5 & 5 & 2 & 4 & 1 \\
\hline 1 & K.1.2.4 & M & 4 & 4 & 3 & 2 & 1 \\
\hline 1 & K.1.2.5 & M & 5 & 5 & 2 & 1 & 1 \\
\hline
\end{tabular}

Keterangan:

$\mathrm{P}$ : Kerangka kerja kebijakan, perencanaan dan legal

$S$ : Dampak sosial

M : Kegiatan kehutanan, produksi barang dan jasa

E : Dampak ekologis

F : Aspek keuangan/finansial dan ekonomi 


\subsection{Contoh Formulir 2}

\section{Pengujian Kriteria dan Indikator: Metode CIFOR}

Formulir 2: Respon di Lapang

\begin{tabular}{l|l|l|l|} 
Inisial Pakar \\
$\mathrm{A}=\ldots \ldots, \mathrm{B}=\ldots \checkmark \ldots$, \\
$\mathrm{C}=\ldots \ldots$,
\end{tabular}$\quad \begin{aligned} & \text { Sumber } \\
& \text { dokumen sumber } \\
& \text { yang ada }\end{aligned}$

Nomor Indentifikasi Akhir. (seperti dilaporkan dalam daftar akhir) Kelompok $\mathrm{S} \quad \begin{aligned} & \text { Kebijakan=P, Sosial=S, Produksi Barang dan Jasa=M, } \\ & \text { Ekologi=E, Aspek Keuangan dan Ekonomi=F }\end{aligned}$
NO. TIM 1

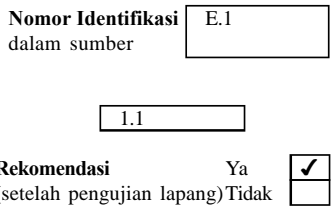

Tuliskan kriteria dan indikator seperti yang tercantum dalam dokumen sumber di sini (gunakan Kotak F untuk versi akhir) Semua stakeholder memiliki hak mengelola yang ditentukan dengan elas dan aman

Berikan alasan Anda untuk pemilihan kriteria dan indikator ini:

Isu-isu kepemilikan tanah merupakan hal paling penting bagi semua PHL yang berhasil dalam waktu dan tempat $\mathrm{B}$

Ciri-ciri Gunakanlah skala 1-5 waktu menjawab, di mana 1=tidak/buruk/tidak penting dan 5=ya/baik/penting $\quad$ C

(d)

(o)

Memberikan ringkasan atau pengukuran yang terintegrasi?

Kaitannya erat dan berhubungan dengan tujuan penilaian?

Respon yang memadai terhadap perubahan

tingkat tekanan? (sensitif)

Secara diagnosis spesifik?

Menarik bagi para pengguna? (d)

(o)

\begin{tabular}{l|l|}
\hline 5 & 5 \\
\hline
\end{tabular} Mudah dideteksi, diukur, dicatat dan ditafsirkan? Layak?

Dapat didefinisikan dengan jelas?

Apakah hasilnya dapat diperbanyak? (dapat dipercaya)

Sejauh mana relevansi kriteria dan indikator 5 ini?

Lainnya:

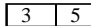

\begin{tabular}{|l|l|}
\hline 5 & 5 \\
\hline
\end{tabular}
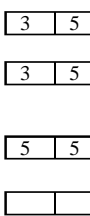

Berikan rujukan pustaka (jika ada):

Berikan rujukan K\&I dalam Set Dasar (contoh: ATO) yang tumpang tindih (sangat mirip) pada kriteria dan indikator yang direkomendasikan di atas:

ATO

DDB

Menyusun set

\begin{tabular}{|c|c|c|c|c|c|c|c|}
\hline & $1-5$ & & $1-5$ & & $1-5$ & $1-5$ & $1-5$ \\
\hline E 1.1 & 4 & E 1.2 & & & & & \\
\hline $6 \mathrm{~A}$ & 2 & & & & & & \\
\hline S 16 & 4 & & & S 21 & & & \\
\hline
\end{tabular}

Versi akhir kriteria/indikator, tuliskan hanya jika berbeda dengan definisi dalam Kotak $A$ :

Dimensi sosial PHL bergantung pada kemanan dan kepemilikan lahan hak hukum adat dan nilai-nilai lainnya dari masyarakat asli 
CATATAN: Tuliskan catatan Anda waktu mengevaluasi kriteria/indikator (Kotak A) di sini:

Kriteria ini cenderung menyimpulkan suatu pengamatan yang diharapkan di lapang. Selanjutnya, tanpa menjaga dan menerima hak lahan dari semua stakeholser yang tercantum dalam konteks, maka barang dan jasa yang tersedia tidak dapat dikelola secara lestari.

Apakah K\&I ini perlu dievaluasi

$\begin{array}{ll}\text { Di lapang? } & \checkmark \\ \text { Di kantor? } & \square\end{array}$

Keduanya?

\section{Catatlah di bawah ini jenis dokumen apa saja yang diperlukan jika K\&I ini digunakan dalam penilaian lapang} untuk menilai pengelolaan hutan lestari. 
Catatan Harian Kegiatan-kegiatan Pokok untuk Mengevaluasi K\&I

\begin{tabular}{|l|l|l|}
\hline Tanggal & Kegiatan & Catatan \\
\hline 27.10 .96 & Wawancara dengan kepala desa & \\
\hline 28.10 .96 & Analisis jender, diskusi dengan beberapa anggota masyarakat & \\
\hline 30.10 .96 & Wawancara dengan pegawai pemerintah Kribi & \\
\hline & & \\
\hline & & \\
\hline & & \\
\hline & & \\
\hline & & \\
\hline & & \\
\hline & & \\
\hline & & \\
\hline & & \\
\hline & & \\
\hline & & \\
\hline & & \\
\hline & & \\
\hline
\end{tabular}




\begin{tabular}{|c|c|c|c|c|c|c|c|c|c|c|}
\hline \multirow{3}{*}{$\begin{array}{l}\text { Fungsi 1 } \\
\text { Alasan }\end{array}$} & \multirow{3}{*}{$\begin{array}{l}\text { Masukan dari } \\
\text { manusia }\end{array}$} & \multirow[t]{2}{*}{ (d) } & \multirow[t]{2}{*}{ (o) } & \multirow{3}{*}{$\begin{array}{l}\text { Proses oleh } \\
\text { manusia }\end{array}$} & \multirow{2}{*}{$\frac{\text { (d) }}{4}$} & \multirow[t]{2}{*}{ (o) } & \multirow[b]{2}{*}{ Keluaran } & \multirow[t]{2}{*}{ (d) } & \multirow[t]{2}{*}{ (o) } & \multirow[t]{2}{*}{$\mathrm{K}$} \\
\hline & & & & & & & & & & \\
\hline & & & & & & & \multicolumn{2}{|c|}{ Pemimpin Tugas: ...... } & & \\
\hline \multirow{3}{*}{$\begin{array}{l}\text { Fungsi } 2 \\
\text { Alasan }\end{array}$} & \multirow{3}{*}{ Tekanan } & (d) & (o) & \multirow{3}{*}{ Pernyataan } & (d) & (o) & \multirow[b]{2}{*}{ Respon } & (d) & $(\mathrm{o})$ & $\overline{\mathrm{L}}$ \\
\hline & & 5 & & & & & & & & \\
\hline & & & & & & & Pemimpin $\mathrm{T}$ & $: \ldots \ldots$ & & \\
\hline
\end{tabular}

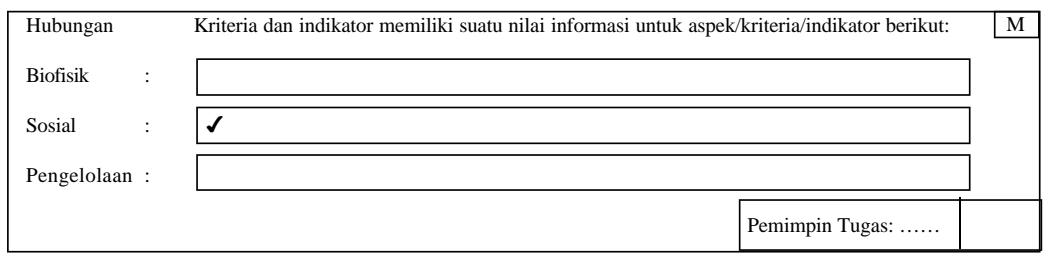

CATATAN PENULIS: Kotak di bawah ini tidak digunakan oleh anggota tim pakar

\begin{tabular}{|c|c|c|c|}
\hline \multicolumn{3}{|c|}{ Catatan Lokakarya (hanya untuk keperluan kantor) } & $\mathrm{N}$ \\
\hline Apakah lokakarya menerima kriteria indikator ini tanpa perubahan? & YA & TIDAK & \\
\hline \multicolumn{3}{|l|}{ Mengapa? } & \\
\hline $\begin{array}{l}\text { Apakah revisi diperlukan? } \\
\text { Tuliskan revisi: }\end{array}$ & YA & TIDAK & \\
\hline \multicolumn{3}{|l|}{ Tuliskan alasan untuk revisi? } & \\
\hline Ataukah kriteria dan indikator ini ditolak karena tidak sesuai? & YA & TIDAK & \\
\hline \multicolumn{3}{|l|}{ Tuliskan alasannya: } & \\
\hline
\end{tabular}




\subsection{PERANGKAT PENILAIAN K\&I SOSIAL}

Beberapa perangkat dasar telah diciptakan dan diuraikan dalam Makalah Kerja CIFOR. Perangkat ini meliputi:

- suatu teknik sederhana untuk membantu para pengelola hutan menentukan stakeholder yang paling relevan yang terkait dalam pengambilan keputusan (Colfer 1995);

- suatu metode untuk menilai tingkat keterlibatan masyarakat lokal dalam pengelolaan sumber daya hutan secara bersama (Colfer dan Wadley 1996);

- satu kelompok yang terdiri dari tiga metode kualiatatif yang dirancang untuk menilai keamanan akses antargenerasi untuk memanfaatkan sumber daya (Colfer dkk. 1997);

- suatu metode untuk menilai persepsi masyarakat tentang hubungan mereka dengan hutan (Colfer dkk. 1996); dan

- sekelompok metode yang dirancang untuk menilai kesejahteraan wanita dan juga pria (termasuk diskusi berbagai masalah terkait) (Colfer dkk. 1997).

Kami masih belum puas dengan berbagai metode ini, dan telah melakukan pengujian tambahan dengan 12 metode untuk menilai kesejahteraan masyarakat. ${ }^{32}$ Metode-metode ini dibagi menjadi tiga topik utama:

32 Metode ini diuraikan lebih terinci dalam pengulangan ketiga (Januari 1997) dari 'paket ilmu sosial' (suatu pengujian metode penilaian ilmu sosial dalam mendefinisikan para pengelola hutan, keamanan akses antargenerasi terhadap sumber daya, dan pengelolaan hutan secara bersama) yang masih sedang dikembangkan oleh CIFOR. 
Penilaian 'siapa yang perlu dipertimbangkan' dalam pengelolaan hutan lestari

- Analisis Kelompok Sasaran

- Analisis CatPac untuk wawancara dengan pertanyaan terbuka dan tercatat, mengenai topik-topik yang berkaitan dengan hutan

- Kuisioner Galileo untuk Menghasilkan Peta Kognitif mengenai Masyarakat dan Sumber Daya Alam

Penilaian keamanan akses antar generasi untuk memanfaatkan sumber daya

- Analisis Kecenderungan Sejarah [juga relevan dengan isu-isu pengelolaan secara bersama]

- Transek Sejarah Lansekap: Dulu, Sekarang, Proyeksi Masa Depan

- Metode Kontinuum Iteratif [juga relevan untuk menilai hak-hak antargenerasi terhadap sumber daya - lihat bagian bawah]

- Pemetaan Partisipatif

- Pembagian Manfaat antara berbagai Stakeholder: Metode Distribusi Kerikil 1

- Akses Suatu Generasi terhadap Sumber Daya: Metode Distribusi Kerikil 2

Penilaian hak dan kewajiban masyarakat untuk mengelola hutan secara bersama-sama (atau untuk berpartisipasi dalam pengelolaan hutan)

- Penyortiran Kartu Partisipasi untuk Isu-isu Pengelolaan Bersama

- Hak dan Kemampuan Mengelola: Metode Distribusi Kerikil 3

- Metode Kontinuum Iteratif [juga relevan untuk keamanan akses terhadap sumber daya antargenerasi]

- Panduan bagi Peneliti tentang Empat Kepentingan Fungsi Partisipasi 


\subsection{CONTOH CARA MENYUSUN TABEL DAN MENYAJIKAN DAFTAR AKHIR K\&I}

\begin{tabular}{|c|c|c|c|c|c|c|c|c|c|}
\hline \multirow[b]{2}{*}{$\mathbf{P}$} & \multirow[b]{2}{*}{ C } & \multirow[b]{2}{*}{$\mathbf{I}$} & \multirow[b]{2}{*}{$\mathbf{V}$} & \multirow[b]{2}{*}{ Uraian } & \multicolumn{5}{|c|}{ Sumber Set K\&I } \\
\hline & & & & & DDB & ITW & LEI & $\mathbf{S A}$ & S W \\
\hline I & & & & $\begin{array}{l}\text { Keutuhan ekosistem hutan } \\
\text { dipelihara. }\end{array}$ & & & & & \\
\hline & 1 & & & $\begin{array}{l}\text { Pemeliharaan fungsi ekosistem } \\
\text { yang terancam tetap terjamin } \\
\text { pada setiap tahap pengelolaan } \\
\text { hutan. }\end{array}$ & & & & & \\
\hline & & 1 & & $\begin{array}{l}\text { Kawasan yang penting secara } \\
\text { ekologis (perlindungan DAS } \\
\text { dan tanah, kawasan dengan } \\
\text { keanekaragaman hayati tinggi, } \\
\text { tingkat endemisme yang tinggi, } \\
\text { adanya jenis langka/terancam } \\
\text { punah, habitat sensitif) } \\
\text { diidentifikasi, dilaporkan dan } \\
\text { secara memadai dikelola atau } \\
\text { dilindungi. }\end{array}$ & & K. 1.5 .3 & & & 5.5 \\
\hline & & 2 & & $\begin{array}{l}\text { Koridor hutan yang belum } \\
\text { dibalak di tepi sungai yang } \\
\text { melintasi lereng dan punggung } \\
\text { bukit, yang menghubungkan } \\
\text { perbatasan daerah resapan dan, } \\
\text { menghubungkan beberapa } \\
\text { bidang lahan hutan yang tidak } \\
\text { akan dikelola tetap } \\
\text { dipertahankan. }\end{array}$ & & K. 1.5 .2 & & $5.108 b$ & 5.6 \\
\hline & & & 1 & $\begin{array}{l}\text { Indeks Perkolasi (Mengukur } \\
\text { hubungan lansekap dari satu } \\
\text { tepi ke tepi lainnya). }\end{array}$ & & & & & \\
\hline
\end{tabular}




\subsection{GLOSARI}

ATO: African Timber Organization. ATO terdiri dari 13 negara penghasil kayu di Afrika yaitu Angola, Kamerun, Republik Afrika Tengah, Kongo, Pantai Gading, Guini, Gabon, Ghana, Liberia, Nigeria, Sao Tome dan Principe serta Zaire. ATO telah melakukan kegiatan pengembangan suatu sistem sertifikasi untuk anggotanya sejak 1993.

Continuous Forest Inventory (CFI): Suatu sistem pengukuran pohon yang dilakukan secara periodik dari tegakan atau plot tertentu untuk mengungkapkan status hutan dan perubahannya dari waktu ke waktu.

CSA: Canadian Standards Association. CSA adalah sebuah asosiasi nirlaba yang bebas, nonpemerintah, yang mengembangkan program standarisasi dan sertifikasi di berberapa bidang termasuk pengembangan standarisasi yang berkaitan dengan pengelolaan hutan lestari.

DDB: Deskundigenwerkgroep Duurzaam Bosbeheer. Sebuah kelompok kerja dari Belanda untuk kriteria and indikator.

FAO: Food and Agriculture Organization sebuah badan di bawah PBB.

FMU: Forest Management Unit (Unit Pengelolaan Hutan). Sebuah kawasan dengan batas yang jelas, sebagian besar tertutup hutan, dikelola dengan serangkaian tujuan yang jelas dan berorientasi pada rencana pengelolaan jangka panjang.

FSC: Forest Stewardship Council. Sebuah LSM internasional beranggotakan para perwakilan dari masyarakat ilmuwan, masyarakat indijenus, bisnis dan LSMLSM lain. FSC memasyarakatkan pengelolaan hutan yang baik dan menjalankan program akreditasi sukarela untuk berbagai organisasi dan perusahaan yang menyediakan sertifikasi dalam sektor kehutanan, tetapi FSC sendiri tidak melakukan sertifikasi. 
Greenpeace: Greenpeace adalah sebuah organisasi yang bebas, yang memasyarakatkan kampanye anti kekerasan, konfrontasi kreatif dalam memecahkan masalah lingkungan global, dan mengusahakan pemecahan yang sangat dibutuhkan untuk masa depan yang hijau dan damai'.

Helsinki \& Montreal Processes: Kelompok kerja yang dibentuk dengan tujuan untuk mengembangkan dan mengimplementasikan $K \& I$ yang disetujui secara internasional untuk pengelolaan hutan lestari.

HHNK: Hasil Hutan Non Kayu seperti madu, rotan, satwa liar dan tanaman obat.

ITTO: Internasional Tropical Timber Organization. Sebuah organisasi antar pemerintah yang bekerja sebagai wadah konsultasi antara produsen dan konsumen dari negara-negara anggota mengenai berbagai aspek ekonomi perkayuan dunia.

ITW: The Initiative Tropenwald. ITW, dibentuk oleh perserikatan perdagangan kayu, para importir dan pengolah kayu di Jerman, pada tahun 1992, kegiatannya adalah mengembangkan suatu proses sertifikasi menggunakan lembagalembaga berakreditasi nasional di dalam negara-negara pengekspor kayu untuk mengeluarkan sertifikat bahwa produsen telah memenuhi standar pengelolaan hutan yang tinggi.

K\&I: Kriteria dan indikator (lihat definisi dan uraian dalam Bab 5.2).

LEI: Lembaga Ekolabel Indonesia (The Indonesian Ecolabeling Institute). Sebuah organisasi yang independen, bekerja melakukan ekolabel di Indonesia.

LSM: Lembaga Swadaya Masyarakat.

Kawasan Hutan Permanen: Berbagai kategori lahan, baik milik umum atau milik pribadi, yang dipertahankan dalam bentuk kawasan hutan. Kategori ini 
mungkin mencakup lahan yang akan dilindungi; lahan untuk konservasi alam, lahan untuk produksi kayu dan hasil hutan lainnya. Dalam kategori ini juga termasuk lahan hutan yang diijinkan untuk pembalakan dan kategori-kategori lahan di mana pembalakan tidak diijinkan.

SCS Inc: Scientific Certification Services. Sebuah organisasi negara AS yang mengembangkan program pemberian label lingkungan. SCS telah menerapkan FCP (Forest Conservation Programme/Program Perlindungan Hutan) di AS dan di tempat lain.

SGS-Forestry/Qualifor: SGS-Forestry adalah sebuah perusahaan jasa pelayanan hutan swasta yang telah mengembangkan suatu program sertifikasi yang disebut Qualifor yang telah diakreditasi oleh Forest Stewardship Council (Dewan Pemeliharaan Hutan).

Sistem TPTI: (Sistem Tebang Pilih Tanam Indonesia). Sistem pemanenan hutan yang diterapkan di Indonesia.

Smartwood: Sebuah program sertifikasi hutan. Diawali oleh Rain-Forest Alliance pada tahun 1989, program ini sekarang merupakan program sertifikasi kehutanan yang tertua dan terbesar dari program yang ada.

TCA: (atau ACT) The Amazon Cooperation Treaty. TCA ditandatangani pada tahun 1978 oleh Bolivia, Brasil, Kolombia, Equador, Guyana, Peru, Suriname dan Venezuela untuk memasyarakatkan pembangunan yang serasi di Lembah Sungai Amazon.

UNEP:United Nations Environment Programme.

Woodmark: Woodmark adalah sebuah skema sertifikasi yang ditujukan untuk memajukan jaringan pengelolaan hutan yang baik. Skema ini dikembangkan oleh Soil Association, sebuah LSM lingkungan. 
WWF: World Wide Fund for Nature. WWF adalah organisasi perlindungan alam yang bebas yang terbesar di dunia. 


\section{Berbagai Kemungkinan Set Dasar Kriteria dan Indikator}

\subsection{ACUAN GENERIK KRITERIA DAN INDIKATOR CIFOR *}

\section{(TANPA PENGUKUR)}

\begin{tabular}{|c|r|r|l|}
\hline $\mathbf{P}$ & $\mathbf{K}$ & $\mathbf{I}$ & \multicolumn{1}{c|}{ DESKRIPSI } \\
\hline $\mathbf{1}$ & & & $\begin{array}{l}\text { Kebijakan, perencanaan dan kerangka kelembagaan mendukung } \\
\text { pengelolaan hutan lestari }\end{array}$ \\
\hline & $\mathbf{1 . 1}$ & & $\begin{array}{l}\text { Dana untuk pengelolaan hutan selalu tersedia dan dalam jumlah } \\
\text { yang memadai }\end{array}$ \\
\hline & 1.1 .1 & $\begin{array}{l}\text { Kebijakan dan perencanaan didasarkan atas informasi yang akurat dan } \\
\text { terkini }\end{array}$ \\
\hline 1.1 .2 & $\begin{array}{l}\text { Ada cara-cara yang efektif dalam koordinasi antarlembaga dalam hal tata } \\
\text { guna lahan dan pengelolaan lahan }\end{array}$ \\
\hline 1.1 .3 & $\begin{array}{l}\text { Adanya kawasan hutan permanen yang merupakan basis pengelolaan hutan } \\
\text { lestari, yang mencakup hutan lindung dan hutan produksi, dan dilindungi } \\
\text { oleh undang-undang }\end{array}$ \\
\hline 1.2 & 1.1 .4 & $\begin{array}{l}\text { Ada rencana tata guna lahan regional, yang menggambarkan berbagai } \\
\text { macam peruntukan lahan hutan, yang memperhatikan nilai-nilai berbagai } \\
\text { faktor seperti jumlah penduduk, pertanian, konservasi, lingkungan dan } \\
\text { budaya }\end{array}$ \\
\hline 1.1 .5 & $\begin{array}{l}\text { Lembaga-lembaga yang bertanggung jawab untuk pengelolaan hutan dan } \\
\text { penelitian mendapat dana dan tenaga yang memadai }\end{array}$ \\
\hline $\begin{array}{l}\text { Ada kebijakan ekonomi yang bersifat pencegahan } \\
\text { Ada dana cadangan untuk mengatasi kerusakan yang mungkin terjadi } \\
\text { (performance bond) }\end{array}$ \\
\hline Berbagai langkah untuk mencegah korupsi sudah dilaksanakan \\
\hline
\end{tabular}

* Dikutip dari Perangkat Seri Kriteria dan Indikator no. 2 


\begin{tabular}{|c|c|c|c|}
\hline & 1.3 & & Kebijakan nonkehutanan tidak mengganggu pengelolaan hutan \\
\hline & & 1.3 .1 & Tidak ada insentif sektor pertanian untuk melakukan perluasan produksi \\
\hline & & 1.3 .2 & Tidak ada pengendalian harga untuk produksi pangan dalam negeri \\
\hline & & 1.3 .3 & Tidak ada pengendalian harga untuk bahan bakar minyak \\
\hline & & 1.3 .4 & Tidak ada kebijakan pemukiman yang mengganggu \\
\hline & & 1.3 .5 & $\begin{array}{l}\text { Tidak ada gangguan dari nilai tukar mata uang yang telalu tinggi atau } \\
\text { terlalu rendah }\end{array}$ \\
\hline & 1.4 & & Ada daerah penyangga yang berfungsi dengan baik \\
\hline & & 1.4 .1 & Tingkat konflik tata batas dalam unit pengelolaan hutan unit (UPH) rendah \\
\hline & & 1.4.2 & Masyarakat lokal menghormati tata batas UPH \\
\hline & & 1.4 .3 & $\begin{array}{l}\text { Pengelola hutan (seperti HPH, Perusahaan kayu) menunjukkan berbagai } \\
\text { upaya untuk melindungi tata batas UPH }\end{array}$ \\
\hline & 1.5 & & $\begin{array}{l}\text { Hukum dan perundang-undangan menjamin akses terhadap } \\
\text { hutan dan sumber daya hutan }\end{array}$ \\
\hline & & 1.5 .1 & Keamanan kepemilikan yang jelas dan didokumentasikan dengan baik \\
\hline & & 1.5 .2 & Ada kebijakan untuk tidak mengambil alih tata guna lahan yang ada \\
\hline & & 1.5 .3 & $\begin{array}{l}\text { Ada hak untuk memungut hasil hutan nonkayu (HHNK) (misalnya, kayu } \\
\text { bakar) }\end{array}$ \\
\hline & & 1.5 .4 & Kebijakan hak kepemilikan lahan tidak mendiskriminasikan hak atas hutan \\
\hline & & 1.5 .5 & Kebijakan penetapan harga kayu bulat/ekspor kayu bulat efisien \\
\hline & & 1.5 .6 & Sistem alokasi lahan pengusahaan hutan berlangsung transparan \\
\hline & 1.6 & & $\begin{array}{l}\text { Ada reinvestasi modal untuk berbagai pilihan kegiatan } \\
\text { pemanfaatan hutan }\end{array}$ \\
\hline & & 1.6 .1 & $\begin{array}{l}\text { Tidak ada pelarian modal secara besar-besaran (mendorong 'tebang dan } \\
\text { lari') }\end{array}$ \\
\hline 2 & & & Pemeliharaan Integritas Ekosistem \\
\hline
\end{tabular}




\begin{tabular}{|c|c|c|}
\hline 2.1 & & $\begin{array}{l}\text { Proses-proses yang menjaga keanekaragaman hayati di dalam } \\
\text { hutan yang dikelola (UPH) dilindungi }\end{array}$ \\
\hline & 2.1 .1 & Pola-pola lansekap tetap dipertahankan \\
\hline & 2.1 .2 & $\begin{array}{l}\text { Perubahan keragaman habitat akibat intervensi manusia tetap dipertahankan } \\
\text { di dalam batas kritisnya seperti ditetapkan oleh variasi alami dan/atau } \\
\text { tujuan konservasi }\end{array}$ \\
\hline & 2.1.3 & $\begin{array}{l}\text { Struktur relung (guilds) komunitas tertentu tidak menunjukkan perubahan } \\
\text { yang berarti, khususnya yang mewakili komunitas tertentu seperti kelompok } \\
\text { penyerbuk dan penyebar biji }\end{array}$ \\
\hline & 2.1.4 & $\begin{array}{l}\text { Tingkat kekayaan/keragaman kelompok-kelompok tertentu tidak } \\
\text { menunjukkan perubahan yang penting }\end{array}$ \\
\hline & 2.1 .5 & $\begin{array}{l}\text { Ukuran populasi dan struktur demografi jenis-jenis tertentu tidak } \\
\text { menunjukkan perubahan yang berarti, dan berbagai tahap dalam siklus } \\
\text { kehidupan secara demografis dan ekologis tetap terwakili }\end{array}$ \\
\hline & 2.1.6 & $\begin{array}{l}\text { Status pembusukan dan unsur hara tidak menunjukkan perubahan yang } \\
\text { berarti }\end{array}$ \\
\hline & 2.1 .7 & $\begin{array}{l}\text { Tidak ada perubahan penting dalam hal kualitas dan kuantitas air dalam } \\
\text { daerah resapan air }\end{array}$ \\
\hline 2.2 & & Berbagai fungsi ekosistem tetap dipelihara \\
\hline & 2.2 .1 & Rantai makanan dan ekosistem tidak terkontaminasi oleh bahan kimia \\
\hline & 2.2 .2 & $\begin{array}{l}\text { Tempat-tempat yang rentan secara ekologis dilindungi, seperti daerah } \\
\text { penyangga yang berada di sepanjang aliran sungai }\end{array}$ \\
\hline & 2.2 .3 & $\begin{array}{l}\text { Tempat-tempat yang mewakili berbagai lokasi yang nilai ekologisnya } \\
\text { penting dilindungi atau dikelola secara tepat }\end{array}$ \\
\hline & 2.2 .4 & Jenis hidupan yang langka atau terancam punah dilindungi \\
\hline & 2.2 .5 & $\begin{array}{l}\text { Erosi dan bentuk-bentuk kemerosotan lahan lainnya dipertahankan sekecil } \\
\text { mungkin }\end{array}$ \\
\hline 2.3 & & Konservasi berbagai proses untuk mempertahankan variasi genetis \\
\hline & 2.3 .1 & $\begin{array}{l}\text { Berbagai tingkat keragaman genetis tetap dipertahankan dalam batas-batas } \\
\text { kritisnya }\end{array}$ \\
\hline
\end{tabular}




\begin{tabular}{|c|c|c|c|}
\hline & & 2.3 .2 & Tidak ada perubahan arah frekuensi genotip \\
\hline & & 2.3 .3 & Tidak ada perubahan dalam aliran/migrasi gen \\
\hline & & 2.3.4 & Tidak ada perubahan dalam sistem perkawinan \\
\hline 3 & & & $\begin{array}{l}\text { Pengelolaan hutan menjaga atau meningkatkan akses antargenerasi } \\
\text { terhadap sumber daya dan berbagai manfaat ekonomi secara adil }\end{array}$ \\
\hline & 3.1 & & $\begin{array}{l}\text { Pihak pengelola lokal dapat secara efektif mengendalikan } \\
\text { pemeliharaan dan akses terhadap sumber daya }\end{array}$ \\
\hline & & 3.1 .1 & $\begin{array}{l}\text { Kepemilikan dan hak pemanfaatan sumber daya (dalam satu generasi atau } \\
\text { antargenerasi) jelas dan mengakui klaim yang sudah ada }\end{array}$ \\
\hline & & 3.1 .2 & $\begin{array}{l}\text { Berbagai aturan dan norma dalam penggunaan sumber daya dipantau dan } \\
\text { ditegakkan pelaksanaannya }\end{array}$ \\
\hline & & 3.1 .3 & $\begin{array}{l}\text { Cara-cara untuk mengatasi konflik berfungsi baik tanpa menggunakan } \\
\text { kekerasan }\end{array}$ \\
\hline & & 3.1 .4 & Akses terhadap sumber daya dianggap adil oleh masyarakat lokal \\
\hline & & 3.1 .5 & Masyarakat lokal merasakan keamanan aksesnya terhadap sumber daya \\
\hline & 3.2 & & $\begin{array}{l}\text { Para pengelola hutan memperoleh manfaat ekonomi yang cukup } \\
\text { dari hasil-hasil hutan yang diambilnya }\end{array}$ \\
\hline & & 3.2 .1 & Mekanisme distribusi manfaat dianggap adil oleh masyarakat lokal \\
\hline & & 3.2 .2 & $\begin{array}{l}\text { Adanya kesempatan bagi masyarakat lokal dan masyarakat yang } \\
\text { menggantungkan hidupnya pada hutan untuk memperoleh pekerjaan dari } \\
\text { perusahaan-perusahaan kehutanan }\end{array}$ \\
\hline & & 3.2 .3 & Upah dan tunjangan lainnya sesuai dengan standar nasional dan/atau ILO \\
\hline & & 3.2 .4 & Ganti rugi terhadap kerusakan diberikan secara adil \\
\hline & & 3.2 .5 & Berbagai hasil hutan digunakan secara optimal dan adil \\
\hline & 3.3 & & $\begin{array}{l}\text { Masyarakat mengaitkan masa depan mereka dan anak-anak } \\
\text { mereka dengan pengelolaan sumber daya hutan }\end{array}$ \\
\hline & & 3.3 .1 & $\begin{array}{l}\text { Masyarakat menanamkan modal di lingkungannya (misalnya, waktu, } \\
\text { tenaga, uang) }\end{array}$ \\
\hline & & 3.3 .2 & Tingkat migrasi keluar rendah \\
\hline
\end{tabular}




\begin{tabular}{|c|c|c|c|}
\hline & & 3.3 .3 & $\begin{array}{l}\text { Masyarakat menyadari pentingnya keseimbangan antara jumlah penduduk } \\
\text { dengan pemanfaatan sumber daya alam }\end{array}$ \\
\hline & & 3.3 .4 & $\begin{array}{l}\text { Anak-anak mendapatkan pendidikan (formal dan informal) tentang } \\
\text { pengelolaan sumber daya alam }\end{array}$ \\
\hline & & 3.3 .5 & Perusakan sumber daya alam oleh masyarakat lokal jarang terjadi \\
\hline & & 3.3 .6 & Masyarakat memelihara hubungan batin dengan lahan hutan \\
\hline 4 & & & $\begin{array}{l}\text { Stakeholder yang relevan memiliki hak dan kemampuan yang } \\
\text { diakui untuk mengelola hutan secara bersama dan adil }\end{array}$ \\
\hline & 4.1 & & $\begin{array}{l}\text { Adanya berbagai mekanisme yang efektif untuk melakukan } \\
\text { komunikasi dua arah antara para stakeholder dalam kaitannya } \\
\text { dengan pengelolaan hutan }\end{array}$ \\
\hline & & 4.1 .1 & $\begin{array}{l}>50 \% \text { dari pegawai Departemen Kehutanan dan Perkebunan dan karyawan } \\
\text { HPH dapat berbicara dalam satu atau beberapa bahasa lokal, atau > } 50 \% \\
\text { wanita lokal dapat menggunakan bahasa yang digunakan oleh HPH dalam } \\
\text { berinteraksi }\end{array}$ \\
\hline & & 4.1 .2 & $\begin{array}{l}\text { Para stakeholder lokal bertemu dengan frekuensi yang cukup, keragaman } \\
\text { lokal cukup terwakili, dan dengan kualitas interaksi yang cukup }\end{array}$ \\
\hline & & 4.1 .3 & $\begin{array}{l}\text { Kontribusi masing-masing stakeholder saling dihormati dan dihargai secara } \\
\text { wajar }\end{array}$ \\
\hline & 4.2 & & $\begin{array}{l}\text { Para stakeholder memiliki pengetahuan yang lengkap tentang } \\
\text { penggunaan sumber daya hutan (termasuk pengetahuan tentang } \\
\text { kelompok-kelompok pengguna hutan dan peranan jender), dan } \\
\text { juga pengetahuan tentang rencana pengelolaan hutan sebelum } \\
\text { rencana tersebut dilaksanakan }\end{array}$ \\
\hline & & 4.2 .1 & $\begin{array}{l}\text { Adanya rencana/peta-peta yang menunjukkan pengintegrasian berbagai } \\
\text { penggunaan hutan oleh berbagai stakeholder yang berbeda }\end{array}$ \\
\hline & & 4.2 .2 & $\begin{array}{l}\text { Rencana yang diperbarui, studi-studi dasar dan peta dapat diperoleh dengan } \\
\text { mudah, yang menunjukkan rincian kawasan seperti penebangan hutan dan } \\
\text { pembangunan jalan, disertai kerangka waktunya }\end{array}$ \\
\hline & & 4.2 .3 & Studi-studi dasar tentang sistem masyarakat lokal juga tersedia dan diacu \\
\hline & & 4.2 .4 & $\begin{array}{l}\text { Pegawai pengelola hutan mengakui adanya berbagai kepentingan dan hak } \\
\text { stakeholder lainnya }\end{array}$ \\
\hline
\end{tabular}




\begin{tabular}{|c|c|c|c|}
\hline & & 4.2 .5 & $\begin{array}{l}\text { Pengelolaan HHNK mencerminkan kepentingan dan hak-hak stakeholder } \\
\text { lokal }\end{array}$ \\
\hline & 4.3 & & $\begin{array}{l}\text { Ada kesepakatan tentang hak-hak dan berbagai kewajiban stake- } \\
\text { holder yang relevan }\end{array}$ \\
\hline & & 4.3 .1 & Tingkat konflik yang ada dapat diterima oleh para stakeholder \\
\hline 5 & & & $\begin{array}{l}\text { Kesehatan hutan, para pengelola hutan dan budayanya dapat } \\
\text { diterima oleh semua stakeholder }\end{array}$ \\
\hline & 5.1 & & $\begin{array}{l}\text { Ada keseimbangan yang cukup baik antara berbagai kegiatan } \\
\text { manusia dan kondisi lingkungannya }\end{array}$ \\
\hline & & 5.1 .1 & $\begin{array}{l}\text { Berbagai kondisi lingkungan yang dipengaruhi oleh kegiatan manusia tetap } \\
\text { dalam keadaan stabil atau membaik }\end{array}$ \\
\hline & & 5.1 .2 & $\begin{array}{l}\text { Migrasi masuk dan/atau pertambahan penduduk secara alami selaras } \\
\text { dengan pemeliharaan hutan }\end{array}$ \\
\hline & 5.2 & & $\begin{array}{l}\text { Ada pengakuan terhadap hubungan antara kesehatan masyarakat } \\
\text { dengan pengelolaan hutan }\end{array}$ \\
\hline & & 5.2 .1 & $\begin{array}{l}\text { Pihak pengelola hutan bekerjasama dengan petugas kesehatan masyarakat } \\
\text { dalam mengatasi berbagai penyakit yang berkaitan dengan pengelolaan } \\
\text { hutan }\end{array}$ \\
\hline & & 5.2 .2 & $\begin{array}{l}\text { Status gizi masyarakat lokal cukup baik (misalnya, tingkat pertumbuhan } \\
\text { tinggi dan berat badan anak-anak sesuai dengan standar internasional, tingkat } \\
\text { kematian bayi dan balita rendah) }\end{array}$ \\
\hline & & 5.2 .3 & $\begin{array}{l}\text { Para pegawai yang bekerja di bidang kehutanan memperhatikan persyaratan- } \\
\text { persyaratan dan keamanan kerja sesuai dengan standar ILO dan bertanggung } \\
\text { jawab atas risiko kesehatan yang berkaitan dengan pekerjaan mereka }\end{array}$ \\
\hline & 5.3 & & $\begin{array}{l}\text { Ada pengakuan terhadap pentingnya keterkaitan antara } \\
\text { pemeliharaan hutan dengan kebudayaan }\end{array}$ \\
\hline & & 5.3 .1 & $\begin{array}{l}\text { Para pengelola hutan dapat menjelaskan keterkaitan antara budaya } \\
\text { masyarakat dengan hutan lokal }\end{array}$ \\
\hline & & 5.3 .2 & $\begin{array}{l}\text { Rencana-rencana pengelolaan hutan mencerminkan perhatian terhadap } \\
\text { isu-isu yang terkait dengan kebudayaan }\end{array}$ \\
\hline & & 5.3 .3 & Tidak ada tanda-tanda tentang adanya perpecahan budaya \\
\hline 6 & & & Hasil dan kualitas barang dan jasa dari hutan bersifat lestari \\
\hline
\end{tabular}




\begin{tabular}{|c|c|c|}
\hline 6.1 & & $\begin{array}{l}\text { Unit Pengelolaan Hutan dilaksanaan berdasarkan kepemilikan } \\
\text { lahan yang sah, dengan mengakui hak-hak adat (tradisional), } \\
\text { atau dengan perjanjian sewa-menyewa yang jelas }\end{array}$ \\
\hline & 6.1 .1 & $\begin{array}{l}\text { Ada dokumen bukti-bukti kesepakatan dengan masyarakat lokal tetang tempat- } \\
\text { tempat di mana pihak pengelola hutan dapat melakukan kegiatannya }\end{array}$ \\
\hline & 6.1 .2 & $\begin{array}{l}\text { Ada informasi tentang identitas, lokasi dan populasi masyarakat indijenus } \\
\text { dan masyarakat tradisional yang hidup di sekitar kawasan hutan yang dikelola } \\
\text { atau masyarakat yang mengklaim kawasan hutan yang dikelola }\end{array}$ \\
\hline & 6.1 .3 & $\begin{array}{l}\text { Ada berbagai bukti atau pernyataan dari perwakilan organisasi-organisasi } \\
\text { masyarakat indijenus atau masyarakat tradisional yang menetapkan luas } \\
\text { wilayah pengelolaan masing-masing, disertai dengan peta-petanya }\end{array}$ \\
\hline 6.2 & & $\begin{array}{l}\text { Sasaran pengelolaan diuraikan secara jelas dan didokumentasikan } \\
\text { dengan baik }\end{array}$ \\
\hline & 6.2 .1 & $\begin{array}{l}\text { Sasaran diuraikan dengan jelas, khususnya dalam hal berbagai fungsi hutan, } \\
\text { dengan memperhatikan aspek-aspek distribusi ruangnya }\end{array}$ \\
\hline 6.3 & & Rencana pengelolaan hutan bersifat komprehensif \\
\hline & 6.3 .1 & Tersedianya rencana pengelolaan hutan yang komprehensif \\
\hline & 6.3 .2 & $\begin{array}{l}\text { Pengelolaan melibatkan berbagai stakeholder yang tepat dan mempertim- } \\
\text { bangkan berbagai fungsi hutan, seperti produksi kayu, HHNK, ekologi dan } \\
\text { kesejahteraan masyarakat lokal }\end{array}$ \\
\hline & 6.3 .3 & $\begin{array}{l}\text { Aturan pengambilan hasil berdasarkan luas hutan atau volume hasil } \\
\text { disebutkan dengan jelas }\end{array}$ \\
\hline & 6.3 .4 & $\begin{array}{l}\text { Sistem silvikultur yang tepat dengan tipe hutan dan hasil hutan yang } \\
\text { diproduksi disebutkan dengan jelas }\end{array}$ \\
\hline & 6.3 .5 & $\begin{array}{l}\text { Sistem pemanenan dan peralatannya ditetapkan sesuai dengan kondisi hutan } \\
\text { untuk mengurangi dampak/pengaruh }\end{array}$ \\
\hline & 6.3 .6 & Rencana pengelolaan secara berkala diserahkan untuk direvisi \\
\hline 6.4 & & Implementasi rencana pengelolaan berlangsung efektif \\
\hline & 6.4 .1 & Unit-unit hutan dibuat zonasinya untuk berbagai tujuan pengelolaan \\
\hline & 6.4 .2 & Tata batas ditandai di lapangan \\
\hline
\end{tabular}




\begin{tabular}{|c|c|c|}
\hline & 6.4 .3 & $\begin{array}{l}\text { Hasil inventarisasi seluruh pemanfaatan hutan dan hasil-hasil hutannya } \\
\text { tersedia }\end{array}$ \\
\hline & 6.4 .4 & $\begin{array}{l}\text { Para karyawan mendapat pelatihan yang memadai untuk melaksanakan } \\
\text { pengelolaan }\end{array}$ \\
\hline & 6.4 .5 & $\begin{array}{l}\text { Infrastruktur disiapkan sebelum pemanenan dan dilakukan sesuai aturan- } \\
\text { aturan pemanenan }\end{array}$ \\
\hline & 6.4 .6 & Kerusakan terhadap tegakan sisa rendah \\
\hline & 6.4 .7 & $\begin{array}{l}\text { Rehabilitasi lahan dan hutan yang terkena dampak dilakukan sesuai dengan } \\
\text { aturan-aturan yang ditetapkan }\end{array}$ \\
\hline & 6.4 .8 & $\begin{array}{l}\text { Tidak ada dampak di luar lokasi seperti dampak kualitas/kuantitas air di } \\
\text { daerah hilir, dampak terhadap infrastruktur dsb. }\end{array}$ \\
\hline & 6.4 .9 & $\begin{array}{l}\text { Berbagai sistem untuk produksi dan transformasi hasil hutan berlangsung } \\
\text { efisien }\end{array}$ \\
\hline 6.5 & & $\begin{array}{l}\text { Sistem pemantauan dan sistem audit terhadap pengelolaan sesuai } \\
\text { dengan perencanaan }\end{array}$ \\
\hline & 6.5 .1 & Petak ukur permanen tetap ada dan dihitung secara teratur \\
\hline & 6.5 .2 & $\begin{array}{l}\text { Semua dokumentasi dan catatan tentang pengelolaan hutan dan berbaga } \\
\text { kegiatan yang terkait dengan pengurusan hutan disimpan dalam kondisi } \\
\text { baik sehingga dapat dimanfaatkan untuk kepentingan pemantauan }\end{array}$ \\
\hline & 6.5 .3 & $\begin{array}{l}\text { Petak kerja dalam keadaan terlindung (misalnya, dari kebakaran, peram- } \\
\text { bahan hutan dan pemanfaatan kembali sebelum waktunya) }\end{array}$ \\
\hline & 6.5 .4 & $\begin{array}{l}\text { Penandaan pohon-pohon sebagai sumber biji dan pohon potensial untuk } \\
\text { pertumbuhan berikutnya dilakukan }\end{array}$ \\
\hline & 6.5 .5 & $\begin{array}{l}\text { Hasil-hasil yang berasal dari pemantauan dan penelitian, dan juga berbaga } \\
\text { informasi ilmiah dan teknis, dimasukkan ke dalam implementasi dan revisi } \\
\text { rencana pengelolaan }\end{array}$ \\
\hline 6.6 & & Keberadaan dan distribusi keuntungan ekonomis dilakukan secara adil \\
\hline & 6.6 .1 & Perkiraan rent capture pemerintah \\
\hline & 6.6 .2 & Perkiraan rent capture operator kehutanan \\
\hline & 6.6 .3 & Perkiraan rent capture masyarakat lokal di hutan \\
\hline
\end{tabular}




\section{BACAAN LEBIH LANJUT}

Prabhu, R., Colfer, C.J.P., Venkateswarlu, P., Tan, L-C., Soekmadi, R. dan Wollenberg, E. 1996. Testing criteria and indicators for sustainable management of forests: Phase I. Final Report. CIFOR Special Publication. CIFOR, Bogor, Indonesia.

Stork, N.E., Boyle, T.J.B., Dale, V., Eeley, H., Finegan, B., Lawes, M., Manokaran, N., Prabhu, R., dan Soberon, J. 1997. Croteria and indicators for assessing the sustainability of forest management: Conservation of biodiversity. CIFOR Working Paper no. 17. CIFOR, Bogor, Indonesia.

Colfer, C.J.P., Brocklesby, M.A., Diaw, C., Etuge, P., Günter, M., Harwell, E., McDougall, C., Porro, N.M., Porro, R., Prabhu, R., Salim, A., Sardjono, M.A., Tchikangwa, B., Tiani, A.M., Wadley, R.L., Woelfel, J. dan Wollenberg, E. 1999. The BAG (Basic assessment guide for human well-being). Criteria \& Indicators Toolbox Series No. 5. CIFOR, Bogor, Indonesia.

Colfer, C.J.P., Brocklesby, M.A., Diaw, C., Etuge, P., Günter, M., Harwell, E., McDougall, C., Porro, N.M., Porro, R., Prabhu, R., Salim, A., Sardjono, M.A., Tchikangwa, B., Tiani, A.M., Wadley, R.L., Woelfel, J. dan Wollenberg, E. 1999. The Grab BAG: Supplementary methods for assessing human wellbeing. Criteria \& Indicators Toolbox Series No. 6. CIFOR, Bogor, Indonesia. 


\subsection{CONTOH LAIN SET K\&I UNTUK TINGKAT UNIT PENGELOLAAN HUTAN (UPH) (DI LUAR CIFOR)}

\subsubsection{LEMBAGA EKOLABEL INDONESIA}

Lembaga Ekolabel Indonesia (LEI) menjelaskan organisasinya sebagai berikut. ${ }^{33}$

Lembaga Ekolabel Indonesia adalah sebuah organisasi nirlaba yang bertugas: (1) untuk meningkatkan tanggung jawab Indonesia dalam melaksanakan pembangunan berkelanjutan, (2) bertindak proaktif dalam memilih sebuah sistem pengelolaan hutan secara lestari, dan (3) menciptakan suatu proses sertifikasi ekolabel yang kemudian memperoleh pengakuan dari negara-negara lain. Pendirian satu lembaga sertifikasi ini di Indonesia bertujuan agar misi dan gagasan yang sama, untuk menilai kinerja UPH akan menjadi kenyataan. Ini merupakan syarat yang penting jika tujuannya adalah untuk menciptakan suatu proses sertifikasi yang efisien, hanya untuk menyutujui satu set kriteria, dan indikator pengelolaan hutan secara lestari.

Satu aspek dari usaha LEI adalah pengembangan set prinsip-prinsip kriteria, dan indikator berikut ini. ${ }^{34}$

${ }^{33}$ Dari web-page LEI di http:/www.iscom.com/ ekolabel/buku0.html (6 Oktober 1997).

${ }^{34}$ Dikutip dari: http://www.iscom.com/-ekolabel/buku1.html (2 Oktober 1997). 


\section{Prinsip-prinsip yang berkaitan dengan pelestarian hasil-hasil hutan}

\section{PRINSIP PERTAMA: KEPASTIAN KEPEMILIKAN LAHAN}

\section{Kriteria 1:}

\section{Batas-batas yang jelas}

Batas sekitar kawasan hutan harus jelas dan dipahami oleh semua pihak yang relevan. Kawasan hutan terdiri dari, kawasan di luar HPH dan kawasan di dalam HPH, terdiri dari (1) petak tebang tahunan dan lima tahunan, (2) kawasan konservasi dan (3) kawasan yang dihuni oleh masyarakat lokal.

\section{Kriteria 2:}

\section{Kawasan bebas konflik}

Proses penetapan batas harus melibatkan partisipasi masyarakat lokal untuk memperoleh hak konsesi, untuk membatasi kemungkinan terjadinya konflik yang muncul selama proses ini.

\section{Kriteria 3:}

\section{HPH harus menjamin keamanan sumber daya hutan}

Sumber daya hutan yang sangat banyak harus dilindungi. HPH bertanggung jawab melakukan hal ini.

\section{PRINSIP KEDUA: MELESTARIKAN HASIL-HASIL HUTAN}

Sistem silvikultur harus diterapkan dalam mengelola hutan. Sistem ini memungkinkan unit pengelolaan untuk menghasilkan hasil-hasil hutan secara terus-menerus. Prinsip ini harus merupakan sistem di mana sistem pemanenan produk dilaksanakan untuk mencapai efisiensi dalam eksploitasi hutan. 
Kriteria 1:

\section{Eksploitasi hasil-hasil hutan harus mengingat daya dukung hutan}

Produksi dan siklus penebangan tahunan harus memungkinkan hutan untuk menghasilkan kembali hasil-hasil yang sama pada tingkat yang sama atau lebih besar daripada periode sebelumnya.

Kriteria 2:

\section{Efisiensi dalam memanen hasil-hasil hutan}

Berbagai kegiatan pemanenan harus didukung oleh kegiatan-kegiatan pembukaan hutan yang meminimalkan dampak dan menjamin keteraturan sepanjang tahun. Limbah hasil penebangan harus dijaga sebisa mungkin pada tingkat paling rendah.

\section{PRINSIP KETIGA: MELESTARIKAN NILAI EKONOMI BAGI PARA STAKEHOLDER}

Pengelolaan hutan juga harus menghasilkan nilai ekonomi, baik untuk unit pengelolaan, masyarakat lokal dan juga untuk pengembangan kawasan. Agar ide ini menjadi kenyataan, pengelolaan hutan harus ditangani oleh pengelola profesional dan dilaksanakan secara profesional.

Kriteria 1:

Peningkatan dampak positif ekonomi bagi para stakeholder Eksploitasi sumber daya hutan harus memberi keuntungan bagi pengusaha, sementara pada saat yang sama memberikan nilai tambah bagi masyarakat dan pembangunan daerah.

Kriteria 2:

Pengelolaan hutan harus didukung oleh tenaga-tenaga profesional 
Jumlah dan kualifikasi tenaga-tenaga profesional pengelolaan hutan harus memadai untuk mencapai tujuan-tujuan pengelolaan hutan secara lestari

\section{Prinsip-prinsip yang berkaitan dengan pelestarian ekosistem hutan}

\section{PRINSIP PERTAMA: REGENERASI, EKOLOGI DAN KESEIMBANGAN EKOSISTEM}

Kapasitas untuk regenerasi adalah kemampuan suatu ekosistem untuk pulih kembali setelah ada gangguan. Stabiliatas ekosistem ditetapkan sebagai suatu keseimbangan dinamis antara jumlah dan struktur ekosistem. Gangguan terhadap kapasitas regenerasi dan stabilitas ekosistem menunjukkan adanya penyimpangan yang besar dalam ekosistem. Penyimpangan ini mungkin bersifat tetap atau, sulit untuk kembali ke keadaan semula.

Kriteria 1:

\section{Memelihara hutan sebagai sarana penopang kehidupan}

Satu fungsi hutan adalah untuk menopang kehidupan. Fungsi ini mungkin akan terpelihara jika sebagian dari ekosistem hutan asli dan plasma nutfah dilindungi. Sarana-sarana agar ekosistem ini berkaitan dengan berbagai ekosistem lain juga harus ada, mungkin melalui sebuah daerah penyangga dan sebuah koridor untuk hidupan liar. Semakin terpelihara suatu ekosistem asli, semakin baik fungsi ekosistem untuk menopang kehidupan.

\section{Kriteria 2:}

\section{Memelihara hutan sebagai pusat keanekaragaman hayati}

Hutan juga berfungsi sebagai pusat keanekaragaman hayati dan fungsi ini harus dipelihara. Nilai sesungguhnya dan nilai potensial hutan tidak 
terhingga. Fungsi ini mungkin bisa diperpanjang jika dampak pembalakan

ditekan seminimum mungkin dan sebagian besar jenis asli dilindungi.

\section{PRINSIP KEDUA: KELANGSUNGAN HIDUP JENIS-JENIS PENENTU/ KUNCI}

Jenis-jenis kunci merupakan jenis-jenis yang memiliki pengaruh besar terhadap keberadaan jenis lain dalam ekosistem. Bila jenis kunci ini menjadi punah, jenis lain dalam beberapa rantai makanan juga akan punah. Umumnya, jenis kunci dapat dikenal dengan mudah sebagai jenis yang bergantung pada hutan. Semakin tinggi kelimpahan jenis kunci dalam sebuah ekosistem hutan yang dieksploitasi, maka dampak negatif dari kegiatankegiatan pembalakan semakin rendah.

Kriteria 1:

\section{Kelimpahan jenis kunci}

Kelimpahan jenis kunci menentukan kualitas ekosistem hutan. Keberhasilan dalam melindungi keberadaan jenis kunci, pada tingkat populasi - yang dapat melanjutkan hidupnya menunjukkan dukungan untuk melindungi ekosistem hutan dari kerusakan karena kegiatankegiatan pembalakan.

\section{Prinsip-prinsip yang berkaitan dengan pelestarian fungsi sosial-budaya hutan}

\section{PRINSIP PERTAMA: KEADILAN}

Keadailan merujuk pada konsep distribusi ideologi negara dan pembangunan. Artinya sumber daya hutan dianggap berkaitan dengan matapencaharian atau 
penghidupan negara. Oleh karena itu pengelolaan secara adil harus mengarah pada peningkatan kesejahteraan bangsa.

Kerangka kerja ini sebenarnya identik dengan salah satu yang digunakan dalam program Bina Desa (Keputusan Menteri Kehutanan no.691/Kpts II/ 1991) SUDAH DIHAPUSKAN; DIGANTI DENGAN SK 69, 1995 TENTANG KEWAJIBAN HPH yang jelas menyatakan tentang tanggung jawab HPH untuk mencoba meningkatkan kesejahteraan masyarakat lokal. Di lain pihak, ada keadilan antargenerasi, khususnya bagi mereka yang matapencahariannya mengandalkan hasil-hasil hutan, dan menghadapi kemungkinan dikucilkan dari hutan, dan dengan demikian menanggung kerugian karena kegiatan penebangan hutan. Kondisi masyarakat yang harus mengorbankan matapencaharian mereka yang mengandalkan hutan adalah tidak sejalan dengan kerangka kerja pembangunan berkelanjutan. Hak untuk hidup dari hasil-hasil hutan harus dinikmati oleh generasi mendatang, tidak hanya generasi kita. Dalam pengelolaan hutan, hak untuk generasi mendatang dalam memilih hidup dari hasil-hasil hutan harus diperhitungkan.

\section{Kriteria 1:}

\section{Kepastian hak-hak tradisional dan kepentingan masyarakat lokal}

Umumnya, sudah ada penduduk di dalam lokasi HPH sebelum kegiatankegiatan penebangan hutan dimulai. Mereka mempunyai pola-pola kehidupan tertentu dan mengandalkan hasil-hasil hutan. Infrastruktur sosial juga ada di tempat ini dan di dalamnya terkandung norma-norma dan nilai-nilai tertentu yang berkaitan dengan hutan. Infrastruktur berperan penting, baik dalam mempertahankan keberadaan masyarakat sebagai suatu entitas, dan sebagai sebuah ciri-ciri keberadaan anggotanya. Unit pengeloaan hutan harus memelihara keberadaan infrastruktur sosial yang penting ini demi kelangsungan hidup masyarakat. Ini mungkin 
dilakukan dengan memperlakukan infrastruktur sebagai bagian integral pengelolaan dan juga dalam memilih kegiatan-kegiatan unit pengelolaan. Ini akan mengurangi kemungkinan konflik yang mengganggu.

Kriteria 2:

\section{Kelanjutan akses terhadap hutan dan hasil-hasil hutan dan pengendaliannya}

Masyarakat lokal mengandalkan hutan sebagai bagian dari matapencaharian mereka. Ketergantungan ini ditentukan oleh tingkat akses dan pengendalian mereka terhadap hutan. Tanpa akses terhadap hutan, masyarakat tidak dapat melanjutkan hidup mereka. Mereka juga akan kehilangan perasaan memiliki dan juga kebanggaan dan kehormatan mereka. Oleh karena itu merupakan keharusan bahwa masyarakat terus memiliki akses dan kendali terhadap hasil-hasil hutan yang merupakan bagian integral kehidupan mereka dan secara tradisional memang adalah milik mereka. Tanpa akses dan kendali tidak mungkin untuk memelihara keamanan dan ketentraman kawasan.

Kriteria 3:

Kehadiran HPH harus memberikan kesempatan kepada masyarakat untuk meningkatkan kualitas hidup mereka

Tujuan pembangunan industri kehutanan adalah meningkatkan kesejahteraan ekonomi penduduk Indonesia. Penduduk yang tinggal di dalam dan di sekitar kawasan HPH adalah bagian dari penduduk Indonesia yang telah hidup di tempat tersebut bertahun-tahun. Oleh karena itu mereka harus menikmati manfaat hasil-hasil pembangunan hutan secara langsung. Tanpa meningkatnya kesejahteraan masyarakat lokal, berbagai usaha untuk mengelola eksploitasi hasil-hasil hutan akan banyak menghadapi masalah. 
Kriteria 4:

Masyarakat lokal harus mampu meningkatkan kemandirian ekonomi dan sosial melalui dukungan dan fasilitas infrastruktur unit pengelolaan hutan

Pembangunan bertujuan untuk memungkinkan baik individu dan kelompok untuk meningkatkan kehidupan di suatu negara merdeka. Kehidupan masyarakat di negara merdeka mengalami kemerdekaan dan kemandirian penuh. Jika kehidupan ekonomi dan sosial yang mandiri tidak ada, ada kemungkinan penduduk bergantung pada unit pengelolaan. Di lain pihak, tanpa bantuan, tingkat konflik akan meningkat.

\section{PRINSIP KEDUA: PERANSERTA MASYARAKAT}

Unit pengelolaan umumnya pendatang baru di suatu kawasan hutan, sementara masyarakat lokal sudah ada sebelumnya di kawasan tersebut sejak lama. Oleh karena itu tepat bila unit pengelolaan sepatutnya melibatkan masyarakat dalam kegiatan-kegiatannya. Keputusan Menteri Kehutanan tahun 1993 menyebutkan bahwa unit pengelolaan harus menghormati hak-hak tradisional masyarakat.

Kriteria 1:

Pengetahuan masyarakat yang berkaitan dengan pengelolaan hutan harus dipadukan dengan pengelolaan hutan secara lestari

Masyarakat, dengan hidup mengandalkan hutan dan tradisinya yang terpadu dengan hutan memiliki pemahaman dan pengetahuan tentang hutan yang baik sekali. Unit pengelolaan harus mengkaji pengetahuan ini sebagai suatu aset yang digunakan dalam pengelolaan hutan secara lestari. Tanpa menggunakan sumber daya yang kaya ini, pengetahuan 
yang bernilai tidak dimanfaatkan sepenuhnya. Kelambatan memahami juga mungkin penyebab punahnya jenis penting.

Kriteria 2:

Peranserta masyarakat dalam mengambil keputusan

Sebagaimana warga negara merdeka lainnya di Indonesia, masyarakat lokal memiliki hak yang sama untuk menentukan masa depan mereka. Oleh karena itu masyarakat berhak berbicara mengenai berbagai hal yang akan menyebabkan perubahan dalam kehidupan mereka. Jika unit pengelolaan hutan memiliki kebijakan atau program yang akan mempengaruhi jalan hidup masyarakat, mereka harus menyediakan kesempatan bagi masyarakat untuk memilih apa yang mereka inginkan untuk hidup mereka. Tanpa adanya kompromi antara apa yang diinginkan unit pengelolaan dan apa yang diinginkan oleh masyarakat, akan muncul konflik dan unit pengelolaan akan menghadapi banyak kesulitan.

\subsection{CONTOH KERANGKA KERJA K\&I UNTUK UPH}

\subsubsection{INTERNATIONAL TROPICAL TIMBER ORGANIZATION (ITTO)}

International Tropical Timber Organization (ITTO) dibentuk melalui suatu perjanjian pada tahun 1983. Tujuan utamanya adalah untuk menyediakan kerangka kerja yang efektif untuk konsultasi di antara anggota-anggota negara penghasil dan konsumen tentang semua aspek ekonomi kayu dunia yang berada dalam mandatnya. Salah satu sasaran ITTO adalah untuk membantu Anggota-anggotanya mencapai sasaran unik ITTO tahun 2000, yang menyatakan bahwa pada tahun 2000 semua hasil-hasil kayu tropis yang diperda- 
gangkan secara internasional melalui Negara-negara Anggota harus berasal dari hutan yang dikelola secara lestari. Lembaga pengurusannya adalah International Tropical Timber Council, yang terdiri dari 53 Anggota dan anggotaanggota ini bertemu tiap dua kali setahun. Pada tanggal 1 Januari 1997, International Tropical Timber Agreement 1994, mulai diberlakukan. ${ }^{35}$

Sebagai bagian dari upaya untuk meningkatkan pengelolaan hutan lestari, ITTO mengembangkan kriteria, dan indikator. Teks berikut dikutip dari sumber ITTO. ${ }^{36}$

\section{Kriteria 1: Menciptakan kondisi-kondisi yang memungkinkan untuk pengelolaan hutan secara lestari}

Kriteria ini meliputi faktor-faktor kelembagaan yang bersifat umum yang diperlukan dalam tindakan-tindakan yang disebutkan di bawah kriteria lain untuk mencapai sasaran, yang membahas masalah-masalah kapasitas lembaga dalam hal kebijakan, peraturan, sumber daya keuangan, penelitian, pegawai yang terlatih, pendidikan dan pelatihan, mekanisme konsultasi dan peranserta, dll. Banyak indikator yang sifatnya deskriptif. Secara keseluruhan, indikator-indikatir ini menunjukkan komitmen politis pada tingkat tertinggi. Ini akan bermanfaat bila negara-negara dapat melengkapi indikator-indikator yang ada dengan menyediakan dokumentasi yang relevan.

\footnotetext{
35 Paragraf ini disadur dari ITTO web-page http://www.itto.or.jp (6 Oktober 1997).

${ }^{36}$ Bagian berikut ini diperoleh dari uraian Laporan panel ITTO tentang indikator dan kriteria. Yokahama, September, 1997. Lampiran 4: Kriteria dan indikator untuk mengukur pengelolaan hutan tropis alami secara lestari. Bagian III. Kriteria dan indikator.
} 


\begin{tabular}{|c|c|c|c|}
\hline \multicolumn{2}{|c|}{$\begin{array}{l}\text { Indikator } \\
\text { Kerangka kerja Legal }\end{array}$} & \multirow{2}{*}{$\begin{array}{c}\text { Nasional } \\
+\end{array}$} & \multirow{2}{*}{$\begin{array}{c}\text { UPH } \\
-\end{array}$} \\
\hline 1.1 & $\begin{array}{l}\text { Ada kebijakan kehutanan yang menjamin keseimbangan } \\
\text { penggunaan sumber daya hutan oleh negara yang } \\
\text { bersangkutan. }\end{array}$ & & \\
\hline 1.2 & $\begin{array}{l}\text { Ada kerangka kerja legal (undang-undang, peraturan, dll) } \\
\text { untuk menentukan: } \\
\text { penetapan dan keamanan kawasan hutan yang permanen, } \\
\text { kontrol terhadap pengelolaan hutan, } \\
\text { kontrol terhadap pemanenan hutan, } \\
\text { kesehatan dan keselamatan. }\end{array}$ & $\begin{array}{l}+ \\
+ \\
+ \\
+\end{array}$ & $\begin{array}{l}- \\
- \\
-\end{array}$ \\
\hline \multicolumn{4}{|c|}{ Kerangka kerja Ekonomi } \\
\hline 1.3 & $\begin{array}{l}\text { Ketersediaan sumber daya keuangan (anggaran) untuk } \\
\text { keperluan pengeluaran, dan untuk investasi dan investasi } \\
\text { kembali dalam pengelolaan hutan, administrasi, penelitian } \\
\text { dan peningkatan sumber daya manusia melalui: } \\
\text { sumber daya nasional, } \\
\text { Bali Partnership Fund, dan } \\
\text { berbagai kontribusi lain dari kalangan internasional. }\end{array}$ & $\begin{array}{l}+ \\
+ \\
+\end{array}$ & $\begin{array}{l}+ \\
+ \\
+\end{array}$ \\
\hline 1.4 & $\begin{array}{l}\text { Struktur kelembagaan yang memadai untuk mendukung } \\
\text { pengelolaan hutan secara lestari. }\end{array}$ & + & + \\
\hline 1.5 & $\begin{array}{l}\text { Jumlah tenaga profesional dan teknisi yang memadai di } \\
\text { semua tingkat untuk melaksanakan tugas-tugas penting } \\
\text { untuk menjamin pengelolaan hutan secara lestari. }\end{array}$ & + & + \\
\hline 1.6 & $\begin{array}{l}\text { Sejumlah tenaga profesional untuk mendukung berbagai } \\
\text { aspek pengelolaan hutan secara lestari: } \\
\text { penelitian, dan } \\
\text { perluasan. }\end{array}$ & $\begin{array}{l}+ \\
+\end{array}$ & $\begin{array}{l}- \\
+\end{array}$ \\
\hline 1.7 & $\begin{array}{l}\text { Ada teknologi yang memadai untuk menerapkan } \\
\text { pengelolaan hutan lestari dan konversi hasil-hasil hutan } \\
\text { yang efisien. }\end{array}$ & + & + \\
\hline 1.8 & $\begin{array}{l}\text { Ada mekanisme pengawasan internal dan kapasitas untuk } \\
\text { memantau secara berkala, evaluasi dan umpan balik }\end{array}$ & + & + \\
\hline
\end{tabular}




\begin{tabular}{|ll|l|l|}
\hline $1.9 \quad \begin{array}{l}\text { kemajuan yang mengarah kepada pengelolaan hutan secara } \\
\text { lestari. }\end{array}$ & $+\begin{array}{l}\text { Tingkat peranserta masyarakat di berbagai tingkat } \\
\text { pengelolaan hutan, seperti perencanaan, pengambilan } \\
\text { keputusan dan pemantauan arah kemajuan pengelolaan } \\
\text { hutan secara lestari. }\end{array}$ & + \\
$1.10 \quad \begin{array}{l}\text { Informasi yang memadai dan tepat waktu untuk mening- } \\
\text { katkan kesadaran masyarakat tentang kebijakan hutan, } \\
\text { undang-undang dan kegiatan-kegiatan pengelolaan hutan } \\
\text { secara lestari. }\end{array}$ & + \\
\hline
\end{tabular}

\section{Kriteria 2: Keamanan sumber daya hutan}

Kriteria keamanan sumber daya hutan ini berkaitan dengan luas kawasan hutan, salah satu dasar untuk praktik-praktik pengelolaan hutan secara lestari. Pengelolaan hutan lestari merupakan usaha jangka panjang dan salah satunya bergantung pada keadaan, stabilitas dan keamanan kawasan hutan negara. Oleh karena itu kriteria ini secara komprehensif mempertimbangkan mana kawasan hutan yang aman dan tetap, baik yang terdiri dari hutan alam dan tanaman, yang cukup untuk memenuhi kebutuhan produksi, perlindungan, konservasi keanekaragaman hayati, dan fungsi-fungsi sosial, budaya dan ekonomi. Kriteria ini juga harus menampung aspirasi generasigenerasi sekarang dan masa depan terhadap hasil-hasil hutan dan berbagai jasa hutan dalam konteks rencana pembangunan ekonomi nasional, dan untuk mencapai pembangunan berkelanjutan. Aspek-aspek legal dan kelembagaan dimasukkan dalam Kriteria 1. 


\begin{tabular}{|c|c|c|c|}
\hline \multicolumn{2}{|c|}{$\begin{array}{l}\text { Indikator } \\
\text { Penjelasan Basis Sumber Daya }\end{array}$} & Nasional & UPH \\
\hline 2.1 & $\begin{array}{l}\text { Luas dan persentase kawasan total, dan ditunjukkan dalam } \\
\text { suatu kurun waktu tertentu: } \\
\text { berupa hutan alami, } \\
\text { berupa hutan tanaman, } \\
\text { berupa kawasan hutan permanen yang dilindungi oleh } \\
\text { undang-undang, dan } \\
\text { di dalam rencana-rencana tata guna lahan yang terinte- } \\
\text { grasi dan komprehensif. }\end{array}$ & $\begin{array}{l}+ \\
+ \\
+ \\
+\end{array}$ & $\begin{array}{l}+ \\
+ \\
+\end{array}$ \\
\hline 2.2 & $\begin{array}{l}\text { Luas dan persentase batas-batas eksternal kawasan hutan } \\
\text { permanen dengan batas-batas yang ditetapkan secara jelas. }\end{array}$ & + & + \\
\hline 2.3 & $\begin{array}{l}\text { Luas dan sifat dari: } \\
\text { eksploitasi ilegal, } \\
\text { perambahan, } \\
\text { peruntukan kembali untuk eksploitasi, } \\
\text { tebang dan bakar, } \\
\text { perburuan ilegal, dan } \\
\text { penambangan. }\end{array}$ & $\begin{array}{l}+ \\
+ \\
+ \\
+ \\
+ \\
+\end{array}$ & $\begin{array}{l}+ \\
+ \\
+ \\
+ \\
+ \\
+\end{array}$ \\
\hline 2.4 & $\begin{array}{l}\text { Kawasan hutan permanen dikonversi menjadi penggunaan } \\
\text { nonhutan permanen, dan ditunjukkan dalam suatu kurun } \\
\text { waktu tertentu. }\end{array}$ & + & - \\
\hline 2.5 & $\begin{array}{l}\text { Meningkatkan kawasan hutan permanen yang didirikan } \\
\text { secara legal, dan ditunjukkan dalam suatu kurun waktu } \\
\text { tertentu. }\end{array}$ & + & - \\
\hline \multicolumn{2}{|c|}{ Prosedur-prosedur Perlindungan } & & \\
\hline 2.6 & $\begin{array}{l}\text { Ada berbagai kebijakan, strategi dan prosedur untuk } \\
\text { mengontrol perambahan ke dalam hutan. }\end{array}$ & + & - \\
\hline
\end{tabular}




\section{Kriteria 3: Kondisi ekosistem hutan}

Kriteria ini berkenaan dengan kualitas hutan dan merupakan landasan untuk berlangsungnya fungsi-fungsi biologis ekosistem hutan secara efisien, dipandang secara terpisah dari komposisi jenis itu sendiri. Kondisi ekosistem hutan dapat diubah baik oleh kegiatan manusia dan peristiwa-peristiwa alam. Contohcontoh pengubahan oleh manusia adalah pencemaran, pengambilan biomassa secara terus-menerus dan terlalu banyak, mengubah penutup hutan dan pemadatan tanah karena kagiatan mesin-mesin, peristiwa alam mencakup, kebakaran hutan, banjir atau siklon. Tidak semua faktor-faktor ini terjadi di negara tertentu atau tipe hutan tertentu, dan tiap negara harus memilih sumber pengubahnya yang pengaruhnya berarti terhadap pengelolaan hutan secara lestari.

Ukuran kuantitatif tanah dan variabel-variabel produktivitas yang akurat hanya dapat diperoleh melalui pencatatan plot-plot sampel permanen secara berkala; tetapi penilaian kualitatif untuk beberapa indikator dilakukan melalui pengamatan yang hati-hati, misalnya dengan membandingkan kawasan yang ditebang dengan contoh kawasan hutan yang tidak terganggu dalam tipe hutan yang sama. Sebaliknya, kerusakan kebakaran mungkin dapat dideteksi melalui teknik penginderaan jauh.

Perubahan kuantitatif di tingkat nasional hanya dapat dinilai melalui pengujian sampel yang dibagi dalam tingkat-tingkat yang dibuat dalam hutan pada tingkat unit pengelolaan hutan.

Di beberapa negara data yang sesuai mungkin tidak tersedia dengan mudah. Dalam kasus-kasus seperti ini, masing-masing negara menilai dirinya sendiri apakah isu-isu yang ada cukup penting pengaruhnya bagi masa depan hutan mereka untuk menjamin pengeluaran waktu dan uang yang diperlukan untuk memperoleh data yang memadai. 


\begin{tabular}{|c|c|c|c|}
\hline \multicolumn{2}{|c|}{$\begin{array}{l}\text { Indikator } \\
\text { Gangguan dan Tekanan }\end{array}$} & Nasional & UPH \\
\hline 3.1 & $\begin{array}{l}\text { Luas hutan dan tingkat kerusakan, dan ditunjukkan dalam } \\
\text { suatu kurun waktu tertentu, disebabkan oleh: } \\
\text { (a) kebakaran, } \\
\text { (b) kemarau, } \\
\text { (c) badai atau bencana alam, dan } \\
\text { (d) kasus-kasus lain seperti perubahan hidrologi, pence- } \\
\text { maran, penyenggutan dan penggembalaan. }\end{array}$ & $\begin{array}{l}+ \\
+ \\
+ \\
+\end{array}$ & $\begin{array}{l}+ \\
+ \\
+ \\
+\end{array}$ \\
\hline \multicolumn{4}{|c|}{ Prosedur-prosedur Konservasi dan Perlindungan } \\
\hline 3.2 & $\begin{array}{l}\text { Tersedia tatacara untuk rancangan jalan hutan, termasuk } \\
\text { syarat-syarat drainase dan konservasi daerah penyangga di } \\
\text { sepanjang aliran sungai. }\end{array}$ & + & + \\
\hline 3.3 & $\begin{array}{l}\text { Adanya prosedur-prosedur: } \\
\text { (a) untuk melindungi tanah dari pemadatan karena } \\
\text { pemanenan oleh mesin selama periode } \\
\text { kelembaban tanah tinggi, } \\
\text { (b) untuk melindungi tanah dari erosi selama operasi } \\
\text { penebangan, dan untuk dampak pembalakan yang } \\
\text { rendah dan untuk mengurangi dampak kerusakan } \\
\text { terhadap tegakan sisa. }\end{array}$ & $\begin{array}{l}+ \\
+ \\
+\end{array}$ & $\begin{array}{l}+ \\
+\end{array}$ \\
\hline 3.4 & $\begin{array}{l}\text { Ada prosedur-prosedur karantina dan pitosanitari untuk } \\
\text { mencegah masuknya berbagai hama dan penyakit. }\end{array}$ & + & - \\
\hline 3.5 & $\begin{array}{l}\text { Ada prosedur-prosedur untuk mencegah introduksi jenis } \\
\text { eksotis yang secara potensial berbahaya. }\end{array}$ & + & - \\
\hline \multicolumn{4}{|c|}{ Pengaruh Iklim } \\
\hline 3.6 & $\begin{array}{l}\text { Total temperatur, sebagai cara-cara untuk menilai iklim } \\
\text { dan indeks kelembaban. }\end{array}$ & + & - \\
\hline 3.7 & $\begin{array}{l}\text { Penyimpanan karbon total dalam tegakan hutan dan } \\
\text { perubahan penyimpanan karbon. }\end{array}$ & + & - \\
\hline
\end{tabular}




\section{Kriteria 4: Aliran hasil-hasil hutan}

Kriteria ini berkaitan dengan pengelolaan hutan untuk produksi kayu dan HHNK. Produksi seperti ini hanya dapat lestari dalam jangka panjang jika hasil-hasil hutan secara ekonomi dan keuangan dapat terus berlangsung. Pendapatan dari hasil-hasil ini salah satunya harus tercermin dalam pembayaran biaya secara penuh, termasuk biaya lingkungan dan sosial.

Hutan yang dikhususkan untuk produksi mampu memenuhi berbagai fungsi hutan lainnya yang penting, seperti melindungi lingkungan dan, sampai tingkat tertentu mendukung pelestarian keanekaragaman hayati. Peran ganda hutan yang beragam ini seharusnya dijaga melalui pelaksanaan praktikpraktik pengelolaan hutan yang memelihara potensi sumber daya hutan untuk menghasilkan berbagai bentuk manfaat bagi masyarakat.

\begin{tabular}{|c|c|c|c|}
\hline \multicolumn{2}{|c|}{$\begin{array}{l}\text { Indikator } \\
\text { Penilaian Sumber Daya }\end{array}$} & Nasional & UPH \\
\hline 4.1 & $\begin{array}{l}\text { Luas dan persentase hutan di mana inventarisasi dan } \\
\text { prosedur-prosedur survei telah digunakan untuk menetapkan: } \\
\text { (a) hasil-hasil hutan utama, } \\
\text { (b) hak-hak dan kepemilikan sumber daya, dan } \\
\text { (c) jumlah masing-masing hasil. }\end{array}$ & $\begin{array}{l}+ \\
+\end{array}$ & $\begin{array}{l}+ \\
+\end{array}$ \\
\hline 4.2 & $\begin{array}{l}\text { Estimasi hasil panen secara lestari (tebangan) untuk masing- } \\
\text { masing kayu utama dan HHNK. }\end{array}$ & + & + \\
\hline 4.3 & $\begin{array}{l}\text { Statistik untuk kayu dan HHNK yang penting, ditunjukkan } \\
\text { dalam suatu kurun waktu tertentu, menurut: } \\
\text { (a) luas, } \\
\text { (b) tipe hutan, dan } \\
\text { (c) jumlah hasil panen. }\end{array}$ & $\begin{array}{l}+ \\
+ \\
+\end{array}$ & $\begin{array}{l}+ \\
+ \\
+\end{array}$ \\
\hline
\end{tabular}




\section{Prosedur-prosedur Perencanaan}

4.4 Luas dan persentase hutan yang dicakup dalam rencanarencana pengelolaan yang terintegrasi, termasuk semua elemen yang diidentifikasi dalam indikator 4.3 - 4.9, dan yang juga memperhitungkan pengaruh lingkungan dalam Kriteria 5 dan 6.

4.5 Luas petak kerja yang dipanen yang memiliki rencanarencana panen (operasi) rinci disiapkan sebelum panen (termasuk luas yang akan dipanen, luas yang akan dilindungi, lokasi jalan dan rel kereta api, dll) (Lihat juga Kriteria 3.2).

4.6 Adanya proyeksi jangka panjang, berbagai strategi dan rencana produksi, termasuk penggunaan hutan tanaman.

4.7 Tersedia catatan yang meliputi luas dan sifat pengelolaan hutan di sekitar kawasan hutan permanen.

\section{Petunjuk-petunjuk Pengelolaan}

4.8 Tersedia petunjuk-petunjuk pengelolaan untuk masingmasing kayu utama dan HHNK yang dipanen.

4.9 Tersedia prosedur untuk memantau dan mengkaji ulang dasar-dasar yang digunakan sebagai petunjuk.

4.10 Ada prosedur-prosedur untuk melengkapi regenerasi alami bila prosedur-prosedur ini tidak efektif.

\section{Prosedur-prosedur Pemantauan dan Evaluasi}

4.11 Persentase luas hutan yang ditebang, yang untuk ini suatu evaluasi komprehensif (tertulis) untuk menilai kelengkapan pelaksanaan petunjuk tersedia.

4.12 Persentase luas hutan yang ditebang di mana survei pascapanen dilakukan, dan persentase luas hutan lain yang memiliki regenerasi efektif dalam semua kelas ukuran termasuk penyemaian. 


\section{Kriteria 5: Keanekaragaman hayati}

Panduan ITTO untuk Konservasi Keanekaragaman Hayati dalam Hutan Produksi Tropis (ITTO Policy Development Series No. 5) menyebutkan prinsipprinsip umum untuk menentukan konservasi keanekaragaman hayati di hutan tropis.

Tindakan-tindakan di tingkat nasional harusnya meliputi:

- Pendirian dan pengelolaan suatu sistem kawasan yang dilindungi (Gabungan dari Kategori IUCN I sampai VI) berisi contoh-contoh wakil dari semua tipe hutan yang ada di dalam suatu negara. Sistem ini, sejauh mungkin diharapkan, mencakup contoh-contoh hutan dalam kondisikondisi aslinya atau mendekati asli. Catatan sejarah tentang hutan ini sebaiknya digunakan bila ada. Jika suatu tipe hutan diketahui telah hilang, usahakan untuk merehabilitasinya. Keefektifan sistem seperti ini tergantung pada luas total kawasan yang dilindungi, persentase dari masing-masing tipe penutup hutan, keterwakilannya, ukuran relatif luas tipe hutan dan lansekap, keadaannya (mencakup ekosistem lain di sekitarnya), dan adanya koridor biologis yang menghubungkan ekosistemekosistem atau 'batu loncatan' di antara sistem-sistem tersebut. Ini dapat dipastikan melalui kebijakan tata guna lahan nasional yang efektif, tata guna lahan hutan dan untuk kawasan yang dilindungi, didukung oleh undang-undang yang tepat dan mekanisme yang efektif untuk pelaksanaan dan penerapannya.

- Perlindungan yang efektif bagi jenis-jenis hidupan, khususnya yang terancam punah, langka atau genting harus ditangani pada tingkat nasional dengan undang-undang satwa yang efektif; dan, pada tingkat unit pengelolaan hutan melalui tatacara pengelolaan. 
- Konservasi keanekaragaman hayati di tingkat yang tepat, di dalam hutan yang dikelola untuk produksi, baik untuk mendukung kualitas hutan (lihat Kriteria 3 - Kondisi ekosistem hutan) dan untuk menyediakan kerangka bagi kawasan yang dilindungi sehingga jaringan kawasan lindung menjadi efektif. Konservasi seperti ini dijamin pelaksanaannya oleh petunjuk-petunjuk pengelolaan untuk hutan yang bersangkutan. Usaha untuk pemanenan hutan dengan berbagai cara harus dilakukan sedemikian rupa sehingga struktur hutan asli terpelihara. Panduan rinci diberikan dalam publikasi ITTO di atas (Recommended Actions 8-17).

\begin{tabular}{|c|c|c|c|}
\hline \multicolumn{2}{|c|}{$\begin{array}{l}\text { Indikator } \\
\text { Keragaman Ekosistem }\end{array}$} & Nasional & UPH \\
\hline 5.1 & $\begin{array}{l}\text { Statistik, untuk masing-masing tipe hutan di dalam negeri } \\
\text { tentang tiap kawasan lindung yang termasuk dalam kategori } \\
\text { kawasan lindung IUCN I sampai VI. Statistik ini harus } \\
\text { meliputi: } \\
\text { (a) jumlah kawasan lindung di tiap-tiap tipe hutan, } \\
\text { (b) luas total kawasan yang berada untuk tiap-tiap tipe hutan, } \\
\text { (c) kisaran ukuran dan ukuran rata-rata kawasan lindung } \\
\text { untuk tiap-tiap tipe hutan, } \\
\text { (d) persentase penutupan tipe hutan, } \\
\text { (e) persentase batas-batas di lapangan atau yang batas- } \\
\text { batasnya jelas, dan } \\
\text { (f) kehadiran koridor-koridor biologis atau 'batu loncatan' } \\
\text { di antara kawasan-kawasan lindung. }\end{array}$ & $\begin{array}{l}+ \\
+ \\
+ \\
+ \\
+\end{array}$ & $\begin{array}{l}- \\
-\end{array}$ \\
\hline \multicolumn{4}{|c|}{ Keanekaragaman Jenis } \\
\hline 5.2 & $\begin{array}{l}\text { Adanya prosedur-prosedur untuk mengidentifikasi jenis } \\
\text { flora dan fauna hutan yang dalam keadaaan bahaya, langka } \\
\text { dan terancam punah. }\end{array}$ & + & + \\
\hline 5.3 & $\begin{array}{l}\text { Jumlah jenis yang dalam keadaan bahaya, langka atau terancam } \\
\text { punah dan persentasenya dalam hubungannya dengan jumlah } \\
\text { jenis total yang ada di hutan. Daftar harus dilampirkan jika ada. }\end{array}$ & + & + \\
\hline
\end{tabular}




\section{Keanekaragaman Genetis}

5.4 Adanya strategi untuk melaksanakan konservasi genetis in situ dan/atau ex situ untuk berbagai jenis flora dan fauna hutan yang komersial, yang dalam keadaan bahaya, langka dan terancam punah.

5.5 Kehadiran petunjuk-petunjuk dan pelaksanaan dan pengelolaan untuk:

(a) menjaga bagian dari tiap-tiap hutan produksi tidak terganggu,

(b) melindungi jenis flora dan fauna hutan yang dalam keadaan bahaya, langka dan terancam punah, dan

(c) melindungi unsur-unsur biologis yang penting, seperti pohon-pohon bibit, lokasi-lokasi sarang, guild dan jenis-jenis kunci.

\section{Prosedur-prosedur Pemantuan dan Evaluasi}

5.6 Suatu ukuran keanekaragaman hayati yang dilindungi di dalam hutan-hutan produksi, dan struktur hutan, berasal dari sampel survei standar yang diulang untuk kelompokkelompok jenis terpilih yang dilakukan dalam kawasan yang dipanen dan kawasan yang tetap bebas dari intervensi manusia.

\section{Kriteria 6: Perlindungan air dan tanah}

Kriteria ini berkaitan dengan fungsi tetap hutan, khususnya yang berhubungan dengan nilai-nilai yang berpengaruh di luar lokasi. Perlindungan air dan tanah penting untuk memelihara produktivitas dan kualitas ekosistem hutan (lihat Kriteria 3 - Kondisi ekosistem hutan); tetapi hutan yang dikelola dengan baik juga berperanan penting dalam memelihara stabilitas aliran dan kualitas air yang berasal dari hutan dan melindungi daerah hilir dari pengaruh banjir berkala dan erosi tanah yang semakin cepat. Dampak lingkungan dan sosial karena pengelolaan yang buruk dapat menjadi sangat serius dan sangat mahal untuk memulihkannya. 
Masing-masing UPH mempunyai ciri-cirinya sendiri dalam hal perlindungan air dan tanah (kemiringan, struktur geologi dan tingkat erodibilitas tipe tanah). Oleh karena itu perlindungan air dan tanah paling baik terjamin oleh adanya panduan khusus untuk situasi-situasi yang berbeda yang hanya dapat didasarkan pada pengalaman dan penelitian. Indikator-indikator nasional yang absah hanya dapat dihasilkan dari kumpulan indikator pada tingkat unit pengelolaan hutan, atau dari kenyataan bahwa ada panduan yang cukup dan dijalankan sebagaimana mestinya.

\begin{tabular}{|ll|c|c|}
\hline Indikator & Nasional & UPH \\
Kadar Perlindungan & $\begin{array}{l}\text { Persentase luas hutan total yang dikelola terutama untuk } \\
\text { perlindungan air dan tanah. }\end{array}$ & + \\
6.2 & $\begin{array}{l}\text { Persentase luas hutan yang ditebang, yang nilai-nilai untuk } \\
\text { daerah resapan di luar lokasinya telah ditentukan dan } \\
\text { didokumentasikan sebelum rencana penebangan. }\end{array}$ & + \\
$6.3 \quad \begin{array}{l}\text { Persentase hutan yang akan ditebang yang telah ditentukan } \\
\text { sebagai kawasan yang lingkungannya rentan (misalnya, sangat } \\
\text { curam atau mudah tererosi) sebelum rencana penebangan. }\end{array}$ & + & + \\
6.4 & $\begin{array}{l}\text { Persentase hutan yang ditebang, yang sistem drainasenya } \\
\text { sudah ada batasnya di lapangan atau ditentukan dengan jelas } \\
\text { sebelum penebangan. }\end{array}$ & + \\
6.5 & $\begin{array}{l}\text { Persentase luas hutan total yang berupa daerah penyangga di } \\
\text { sepanjang aliran air, badan air dan kawasan lain, yang sesuai, } \\
\text { seperti hutan-hutan mangrove dan kawasan basah lainnya. }\end{array}$ & + \\
$6.6 \quad \begin{array}{l}\text { Persentase luas daerah penyangga total sepanjang aliran } \\
\text { yang dilindungi selama penebangan hutan berlangsung. }\end{array}$ & + \\
Prosedur-prosedur Perlindungan \\
6.7 & + & + \\
\hline
\end{tabular}


(a) penggunaan bahan-bahan kimia di dalam hutan, dan

(b) pengelolaan kebakaran.

$\begin{array}{ll}+ & + \\ + & +\end{array}$

\section{Kriteria 7: Pengaruh-pengaruh sosial, budaya dan ekonomi}

Kriteria ini berkaitan dengan pengaruh hutan yang dikelola secara lestari terhadap kondisi sosial, budaya dan ekonomi, selain pengaruh-pengaruh yang disebutkan dalam Kriteria 4 - Aliran hasil-hasil hutan, Kriteria 5 Keanekaragaman hayati dan Kriteria 6-Perlindungan/pemeliharaan tanah dan air.

Hutan yang dikelola dengan baik merupakan suatu sumber daya yang terus membarui dengan sendirinya, jika secara ekonomi dapat berjalan, akan meningkatkan pengaruh sosial, budaya dan ekonomi, memberi masukan penting bagi pembangunan negara yang berkelanjutan.

\begin{tabular}{|c|c|c|c|}
\hline \multicolumn{2}{|c|}{$\begin{array}{l}\text { Indikator } \\
\text { Pengaruh Ekonomi }\end{array}$} & Nasional & UPH \\
\hline 7.1 & $\begin{array}{l}\text { Investasi total dalam sektor kehutanan dan sektor-sektor yang } \\
\text { terkait, dan ditunjukkan dalam suatu kurun waktu tertentu. }\end{array}$ & + & + \\
\hline 7.2 & $\begin{array}{l}\text { Jumlah lapangan kerja di bidang kehutanan secara langsung } \\
\text { dan tidak langsung dan sektor-sektor terkait sebagai persen- } \\
\text { tase lapangan kerja total, dan ditunjukkan dalam suatu kurun } \\
\text { waktu tertentu. }\end{array}$ & + & + \\
\hline 7.3 & $\begin{array}{l}\text { Volume dan nilai kayu dan HHNK yang diperdagangkan di: } \\
\text { (a) pasar dalam negeri, dan } \\
\text { (b) pasar internasional, dan ditunjukkan dalam suatu kurun } \\
\text { waktu tertentu. }\end{array}$ & $\begin{array}{l}+ \\
+\end{array}$ & $\begin{array}{l}+ \\
+\end{array}$ \\
\hline 7.4 & $\begin{array}{l}\text { Volume dan nilai kayu dan HHNK, termasuk kayu bakar } \\
\text { untuk kegunaan subsisten. }\end{array}$ & + & + \\
\hline
\end{tabular}


7.5 Ada mekanisme distribusi insentif yang efisien dan adil dalam pembagian biaya dan manfaat yang pantas untuk pihak-pihak yang terlibat.

7.6 Rasio produksi kayu bulat dalam negeri terhadap kapasitas pengolahan industri berbasis kayu, dan ditunjukkan dalam suatu kurun waktu tertentu.

7.7 Efisiensi Pemanfaatan:

(a) persentase sisa volume kayu di dalam hutan yang masih dapat dimanfaatkan, dan

(b) laju pemulihan perusahaan pengolah kayu.

7.8 Nilai dan persentase sektor kehutanan terhadap Pendapatan Kotor Nasional, dan ditunjukkan dalam suatu kurun waktu tertentu.

7.9 Jumlah penduduk yang mengandalkan hutan karena tradisi dan gaya hidupnya.

7.10 Jumlah lokasi hutan rekreasi yang didirikan dan tersedia untuk digunakan oleh masyarakat umum dan jumlah pengunjung ke lokasi-lokasi tersebut.

7.11 Jumlah lokasi hutan yang tersedia untuk:

(a) penelitian, dan

(b) pendidikan.

7.12 Luas hutan yang ditanami pohon buah-buahan dan jenis pohon lainnya yang dikelola untuk dimanfaatkan langsung dan berguna bagi masyarakat lokal, dan ditunjukkan dalam suatu kurun waktu tertentu.

\section{Pengaruh-pangaruh Budaya}

7.13 Jumlah lokasi purbakala yang penting dan lokasi budaya diketahui, dipetakan dan dilindungi.

\section{Peranserta Masyarakat}

7.14 Luas kawasan kepemilikan dan hak-hak guna atas hutan didokumentasikan. 


\begin{tabular}{|c|c|c|c|}
\hline 7.15 & $\begin{array}{l}\text { Adanya prosedur-prosedur yang memberi kesempatan pada } \\
\text { perencanaan hutan dan kegiatan-kegiatan pengelolaan dan } \\
\text { pertimbangan untuk memenuhi proses-proses legal } \\
\text { atau hak-hak adat yang berkaitan dengan masyarakat indijenus } \\
\text { dan masyarakat lokal, penduduk hutan, dan masyarakat lain } \\
\text { yang bergantung pada hutan. }\end{array}$ & + & + \\
\hline 7.16 & $\begin{array}{l}\text { Besarnya peranserta masyarakat indijenus dan masyarakat } \\
\text { lokal, penduduk hutan dan masyarakat lain yang bergan- } \\
\text { tung pada hutan di dalam kegiatan-kegiatan ekonomi yang } \\
\text { bersumber pada hutan. }\end{array}$ & + & + \\
\hline 7.17 & $\begin{array}{l}\text { Jumlah kesepakatan yang melibatkan masyarakat lokal } \\
\text { dalam hal tanggung jawab bersama dalam bidang pengelola- } \\
\text { an hutan secara lestari. }\end{array}$ & + & - \\
\hline
\end{tabular}

\subsubsection{FOREST STEWARDSHIP COUNCIL (FSC)}

FSC, merupakan sebuah LSM internasional yang terdiri dari wakil-wakil yang berasal dari masyarakat ilmuwan, masyarakat indijenus, pengusaha dan LSM-LSM lainnya. Dewan ini bergerak di bidang kelembagaan internasional untuk sistem-sistem akreditasi nasional dan sertifikasi lokal. Prinsip-prinsip dan kriteria yang dibuat oleh FSC pada awal tahun 1994 tidak hanya meliputi praktik-praktik pengelolaan hutan, tetapi juga aspek-aspek penggunaan hutan dari segi sosial dan legal, kepatuhan terhadap hukum-hukum nasional dan kesepakatan internasional, kepemilikan lahan secara legal, hak-hak, masyarakat indijenus terhadap sumber daya hutan di lahan mereka, kesejahteraan para pekerja, dampak sosial kegiatan-kegiatan kehutanan bagi masyarakat. Sekretariat FSC telah meluncurkan berbagai panduan bagi lembaga sertifikasi dan penjelasan prosesnya yang akan diadopsi untuk mengakreditasikan sertifikasi. Beberapa prasyarat akreditasi antara lain 
adalah bebas dari kepentingan kelompok dan terbuka, proses-proses dapat dipertanggungjawabkan. ${ }^{37}$

Setelah prinsip-prinsip dan kriteria dikembangkan oleh FSC, prinsip-prinsip 1 - 9 diratifikasi oleh Anggota Dewan Pendanaan dan Dewan Direktur pada bulan September 1994. Prinsip 10 diratifikasi oleh Anggota FSC dan Dewan Direktur pada bulan Pebruari 1996.

\section{PRINSIP 1: KEPATUHAN TERHADAP HUKUM-HUKUM DAN PRINSIP-PRINSIP FSC}

Pengelolaan hutan harus mematuhi semua hukum yang berlaku di negara tempat mereka tinggal, dan perjanjian dan kesepakatan internasional di mana suatu negara adalah salah satu yang menandatangani dan memenuhi semua Prinsip dan Kriteria FSC.

1.1 Pengelolaan hutan mematuhi semua hukum nasional dan lokal dan syarat-syarat administrasi.

1.2 Semua biaya yang dikenakan ditentukan secara legal, royalti-royalti, pajak-pajak dan beban lain harus dibayar.

1.3 Di negara-negara penandatanganan perjanjian, ketetapan dari semua kesepakatan internasional yang mengikat seperti CITES, Perjanjianperjanjian ILO, ITTA, dan Ketentuan Keanekaragaman Hayati, harus dipatuhi.

1.4 Konflik-konflik di antara undang-undang, peraturan dan Prinsip dan Kriteria FSC harus dievaluasi untuk kepentingan sertifikasi, berdasarkan

37 Paragraf ini disadur dari ringkasan yang disediakan oleh World Resources Institute di http://www.igc.apc.org/wri/biodiv/opp-bx2.html\#FSC (6 Ockober 1997). 
kasus demi kasus, oleh lembaga sertifikasi bersama pihak-pihak yang terlibat atau yang terpengaruhi.

1.5 Kawasan pengelolaan hutan harus dilindungi dari penebangan ilegal, pemukiman dan kegiatan-kegiatan lain yang tidak legal.

1.6 Para pengelola hutan harus menunjukkan komitmen jangka panjang untuk mematuhi Prinsip dan Kriteria FSC.

PRINSIP 2: KEPEMILIKAN DAN HAK-HAK GUNA DAN TANGGUNG JAWABNYA

Kepemilikan jangka panjang dan hak-hak guna atas lahan dan sumber daya hutan harus ditentukan secara jelas, didokumentasikan dan dibuat secara legal.

2.1 Bukti yang jelas adanya hak-hak guna atas hutan dalam jangka panjang (misalnya, status lahan, hak-hak adat, kesepakatan kontrak) harus ditunjukkan.

2.2 Masyarakat lokal yang memiliki lahan adat legal atau hak-hak guna atas lahan harus tetap memiliki kendali, sejauh untuk kepentingan melindungi hak-hak atau sumber daya mereka, atas operasi hutan kecuali mereka mewakili pengendalian secara bebas dan melalui persetujuan mereka kepada lembaga-lembaga lain.

2.3 Berbagai mekanisme yang sesuai perlu digunakan untuk memecahkan konflik mengenai tuntutan kepemilikan dan hak-hak guna. Keadaan dan status berbagai konflik yang masih ada secara eksplisit akan dipertimbangkan dalam evaluasi sertifikasi. Konflik yang secara substansial serius dan melibatkan berbagai kepentingan biasanya akan menyebabkan operasi dibatalkan untuk menerima sertifikasi. 


\section{PRINSIP 3: HAK-HAK MASYARAKAT INDIJENUS}

Hak legal dan hak adat masyarakat indijenus untuk memiliki, menggunakan dan mengelola lahan, wilayah, dan sumber daya mereka harus diakui dan dihormati.

3.1 Masyarakat indijenus berhak mengendalikan pengelolaan hutan mereka dan wilayahnya kecuali mereka mewakilkan pengendalian secara bebas dan melalui persetujuan mereka kepada lembaga-lembaga lain.

3.2 Pengelolaan hutan tidak boleh mengancam atau mengurangi baik secara langsung atau tidak langsung sumber daya atau hak kepemilikan masyarakat indijenus.

3.3 Tempat-tempat yang memiliki nilai budaya tertentu, ekologi, ekonomi atau kepentingan keagamaan bagi masyarakat indijenus harus ditentukan dengan jelas bersama dengan masyarakat tersebut, dan diakui dan dilindungi oleh para pengelola hutan.

3.4 Masyarakat indijenus harus diberi ganti rugi untuk penggunaan pengetahuan tradisional mereka mengenai penggunaan jenis hutan atau sistemsistem pengelolaan dalam kegiatan kehutanan. Ganti rugi ini harus disepakati secara resmi dengan bebas dan disetujui setelah masyarakat mendapat informasi yang benar, sebelum operasi-operasi kehutannya dimulai.

\section{PRINSIP 4: HUBUNGAN MASYARAKAT DAN HAK-HAK PEKERJA}

Kegiatan-kegiatan pengelolaan hutan harus memelihara atau meningkatkan kesejahteraan sosial dan ekonomi para pekerja hutan dan masyarakat lokal dalam jangka panjang.

4.1 Masyarakat yang hidup di dalam hutan atau berbatasan dengan kawasan pengelolaan hutan perlu diberi kesempatan pekerjaan, pelatihan dan atau pelayanan lainnya. 
4.2 Pengelolaan hutan harus patuh atau menerapkan standar hukum dan/ atau peraturan yang lebih tinggi untuk mengatur kesehatan dan keamanan para pekerja dan keluarganya.

4.3 Hak-hak para pekerja untuk mengatur dan dengan sukarela melakukan negosiasi dengan perusahaan-perusahaan tempat mereka bekerja harus terjamin seperti dalam Ketentuan International Labour Organization (ILO) 87 dan 98.

4.4 Rencana pengelolaan dan pengoperasiannya perlu memasukkan hasilhasil evaluasi terhadap dampak sosial. Konsultasi dengan penduduk dan kelompok-kelompok masyarakat yang secara langsung dipengaruhi oleh kegiatan-kegiatan pengelolaan yang perlu tetap dipelihara.

4.5 Berbagai mekanisme yang sesuai perlu diterapkan untuk mengatasi keluhan-keluhan dan untuk menyediakan ganti rugi yang adil dalam kasus kerusakan atau kehilangan yang mempengaruhi hak-hak legal atau adat, harta benda, sumber daya, atau matapencaharian penduduk lokal. Berbagai tindakan untuk menghindari kehilangan atau kerusakan seperti ini perlu dilakukan.

\section{PRINSIP 5: BERBAGAI MANFAAT DARI HUTAN}

Berbagai kegiatan pengelolaan hutan perlu mendukung efisiensi penggunaan berbagai hasil-hasil jasa hutan dan untuk menjamin kelangsungan ekonomi berbagai bentuk pemanfaatan lingkungan dan manfaat sosial hutan.

5.1 Pengelolaan hutan perlu berusaha menjaga kelangsungan ekonomi, sementara tetap memasukkan unsur biaya lingkungan, sosial dan kegiatan produksi, dan menjamin bahwa keperluan penanaman modal adalah untuk memelihara produktivitas ekologi hutan. 
5.2 Pengelolaan hutan dan kegiatan-kegiatan pemasaran perlu mendukung penggunaan dan pengelolaan lokal hasil hutan yang beragam secara optimal.

5.3 Pengelolaan hutan perlu meminimalkan limbah yang dihasilkan dari penebangan dan kegiatan-kegiatan pengolahan di lokasi dan menghindari kerusakan terhadap sumber daya hutan lainnya.

5.4 Pengelolaan hutan perlu berusaha memperkuat dan melakukan diversifikasi ekonomi lokal, menghindari ketergantungan pada satu jenis hasil hutan saja.

5.5 Pengelolaan hutan perlu mengakui, menjaga dan, bila mungkin, meningkatkan nilai-nilai pelayanan hutan dan sumber daya seperti DAS dan perikanan.

5.6 Laju pemanenan hasil-hasil hutan tidak boleh lebih dari tingkat yang dapat dipertahankan secara lestari.

\section{PRINSIP 6: DAMPAK LINGKUNGAN}

Pengelolaan hutan perlu melestarikan keanekaragaman hayati dan nilai-nilai yang berkaitan dengannya, sumber daya alam, tanah, berbagai ekosistem dan lansekap yang rentan dan unik, dan dengan demikian memelihara fungsifungsi ekologis dan keutuhan hutan.

6.1 Penilaian dampak lingkungan perlu dilengkapi - sesuai dengan skala, intensitas pengelolaan hutan dan keunikan sumber daya yang dipengaruhi - dan dimasukkan ke dalam sistem-sistem pengelolaan. Penilaian ini harus mencakup pertimbangan tingkat lansekap begitu juga dampak berbagai fasilitas pengolahan di lokasi. Berbagai dampak lingkungan harus dinilai sebelum kegiatan-kegiatan yang mengganggu di lokasi mulai berlangsung. 
6.2 Usaha perlindungan terhadap jenis-jenis yang berada dalam bahaya dan terancam punah dan habitatnya (misalnya, kawasan perkembangbiakan dan tempat makan) perlu dilakukan. Wilayah konservasi dan kawasan lindung perlu dibentuk, sesuai skala dan intensitas pengelolaan hutan dan keunikan sumber daya yang dipengaruhi. Perburuan, pemancingan, penangkapan dan pengumpulan hasil hutan yang tidak diijinkan harus dikendalikan.

6.3 Berbagai fungsi ekologis dan nilai-nilainya perlu dipelihara keutuhannya, ditingkatkan atau dipulihkan, meliputi:

1. Regenerasi hutan dan suksesinya

2. Keanekaragaman genetis, jenis, dan ekosistem

3. Siklus alami yang mempengaruhi produktivitas ekosistem hutan

6.4 Contoh-contoh perwakilan ekosistem yang ada dalam lansekap harus dilindungi dalam kondisi alaminya dan dicatat di peta, sesuai skala dan intensitas operasi dan keunikan sumber daya yang dipengaruhi.

6.5 Panduan tertulis perlu disiapkan dan diterapkan untuk: mengendalikan erosi; meminimumkan kerusakan hutan selama penebangan, konstruksi jalan, dan semua gangguan-gangguan mekanis lainnya; dan melindungi sumber daya air.

6.6 Sistem pengelolaan hutan perlu mendorong pengembangan dan adopsi metode-metode pengendalian hama tanpa bahan kimia dan yang ramah lingkungan dan berusaha menghindari penggunaan pestisida kimia. Pestisida World Health Organization Type 1A dan 1B dan pestisida hidrokarbon yang diklorinasi; pestisida yang persisten, beracun atau zatzat yang diturunkannya tetap aktif secara biologi dan menumpuk dalam rantai makanan melebihi kepentingan kebutuhannya; begitu juga berbagai pestisida yang dilarang oleh kesepakatan internasional perlu dilarang penggunaannya. Bila bahan-bahan kimia digunakan, sebaiknya 
peralatan dan pelatihan dilakukan dengan sungguh untuk meminimalkan risiko-risiko yang mengancam kesehatan dan lingkungan.

6.7 Bahan-bahan kimia, botol-botol, limbah cair dan padatan nonorganik termasuk bahan bakar dan minyak harus dibuang dengan cara-cara yang ramah lingkungan dan di luar lokasi operasi.

6.8 Penggunaan agen-agen pengendalian biologis harus didokumentasikan, diminimalkan, dipantau dan dikendalikan secara ketat sesuai dengan hukum-hukum nasional dan protokol ilmiah yang secara internasional dapat diterima. Penggunaan organisme-organisme yang secara genetis dimodifikasi harus dilarang.

6.9 Penggunaan jenis eksotis harus dikendalikan secara hati-hati dan dipantau secara aktif untuk menghindari dampak-dampak ekologi yang merugikan.

\section{PRINSIP 7: RENCANAPENGELOLAAN}

Sebuah rencana pengelolaan - sesuai dengan skala dan intensitas operasiperlu disiapkan secara tertulis, dilaksanakan dan terus diperbarui. Sasaran pengelolaan jangka panjang, dan cara-cara mencapainya, perlu disebutkan dengan jelas.

7.1 Rencana pengelolaan dan dokumen-dokumen pendukung perlu menyebutkan:

1. Sasaran pengelolaan.

2. Deskripsi sumber daya hutan yang akan dikelola, berbagai keterbatasan lingkungan, status tata guna lahan dan kepemilikan, kondisi-kondisi sosial ekonomi, dan profil lahan yang berdekatan.

3. Deskripsi silvikultur dan/atau sistem pengelolaan lain, berdasarkan ekologi hutan yang bersangkutan dan informasi yang dikumpulkan melalui inventarisasi sumber daya. 
4. Alasan laju tebangan tahunan dan pemilihan jenis.

5. Ketentuan-ketentuan untuk memantau pertumbuhan hutan dan dinamikanya.

6. Usaha perlindungan lingkungan berdasarkan hasil penilaian lingkungan.

7. Rencana-rencana untuk pengidentifikasian dan perlindungan jenis yang dalam keadaan bahaya, langka dan terancam punah.

8. Peta-peta yang menggambarkan basis sumber daya hutan meliputi kawasan lindung, berbagai kegiatan pengelolaan yang direncanakan dan kepemilikan lahan.

9. Deskripsi dan teknik-teknik penebangan yang adil dan peralatan yang digunakan.

7.2 Rencana pengelolaan perlu direvisi secara berkala untuk menggambarkan hasil-hasil pemantuan atau informasi ilmiah dan teknik baru, begitu juga untuk menanggapi perubahan keadaan lingkungan, sosial dan ekonomi.

7.3 Para pekerja perlu diberi pelatihan dan pengawasan yang cukup untuk menjamin pelaksanaan rencana pengelolaan secara tepat.

7.4 Sementara menghormati kerahasiaan informasi, para pengelola perlu membuat ringkasan elemen-elemen utama rencana pengelolaan yang tersedia bagi masyarakat umum, termasuk yang terdaftar dalam Kriteria 7.1.

\section{PRINSIP 8: PEMANTAUAN DAN PENILAIAN}

Pemantauan perlu dilakukan - sesuai dengan skala dan intensitas pengelolaan hutan - untuk menilai kondisi-kondisi hutan, jumlah hasil-hasil hutan, rantai pengawasan, kegiatan-kegiatan pengelolaan dan dampak-dampak sosial dan lingkungan yang ditimbulkannya. 
8.1 Frekuensi dan intensitas pemantauan perlu ditentukan melalui skala dan intensitas kegiatan-kegiatan pengelolaan hutan begitu juga kerumitan relatif dan rapuhnya lingkungan yang dipengaruhi. Prosedurprosedur pemantauan harus konsisten dan dapat diulang dalam suatu kurun waktu dengan membandingkan hasil-hasil dan penilaian terhadap perubahan.

8.2 Pengelolaan hutan harus mencakup penelitian dan pengumpulan data yang diperlukan untuk memantau, paling sedikit untuk indikatorindikator berikut:

1. Jumlah semua hasil-hasil hutan yang dipanen

2. Laju pertumbuhan, regenerasi dan kondisi hutan

3. Komposisi dan perubahan-perubahan flora dan fauna yang dapat diamati

4. Berbagai dampak lingkungan dan sosial dari penebangan dan kegiatan lainnya

5. Biaya, produktivitas dan efisiensi pengelolaan hutan

8.3 Pendokumentasian harus disediakan oleh pengelola hutan untuk memungkinkan badan pemantauan sertifikasi melacak masing-masing hasil hutan dari hasil hutan yang asli, proses ini diketahui sebagai 'rantai pengawasan'.

8.4 Hasil-hasil pemantauan harus dimasukkan ke dalam penerapan dan revisi rencana pengelolaan.

8.5 Sementara menghormati kerahasiaan informasi, para pengelola perlu membuat ringkasan hasil-hasil indikator pemantauan, termasuk yang terdaftar dalam Kriteria 8.2. 


\section{PRINSIP 9: PEMELIHARAAN HUTAN ALAM}

Hutan primer, hutan sekunder yang sudah tumbuh dengan baik dan tempattempat yang memiliki lingkungan, sosial atau budaya yang penting perlu dilindungi. Kawasan-kawasan seperti ini seharusnya tidak digantikan oleh hutan tanaman atau berbagai bentuk penggunaan lahan lainnya.

9.1 Pohon-pohon yang ditanam dalam hutan alam mungkin melengkapi regenerasi alami, mengisi rimpang atau memberi andil untuk konservasi plasma nutfah. Kawasan hutan seperti ini seharusnya tidak diganti atau yang secara berarti mengubah ekosistem alami.

9.2 Penanaman ulang sebagai suatu teknik untuk mempertahankan regenerasi tipe-tipe hutan alami tertentu mungkin cocok untuk keadaankeadaan tertentu. Panduan untuk intensitas penanaman yang dapat diterima dan luasnya penanaman akan diatur sesuai standar-standar pengelolaan hutan nasional dan regional yang diakui oleh FSC. Jika standar nasional dan regional tersebut tidak ada, panduan yang dikembangkan oleh lembaga sertifikasi dan diakui oleh FSC akan berlaku.

\section{PRINSIP 10: HUTAN TANAMAN}

Hutan tanaman harus direncanakan dan dikelola sesuai dengan Prinsip-prinsip dan Kriteria 1 - 9, dan Prinsip 10 dan Kriterianya. Sementara hutan tanaman dapat menyediakan berbagai bentuk manfaat sosial dan ekonomi, dan dapat memenuhi kebutuhan dunia akan hasil-hasil hutan secara memuaskan, hutan tanaman harus melengkapi pengelolaan hasil-hasil hutan, mengurangi tekanan terhadap hasil-hasil hutan alami, dan mendorong pemulihan dan konservasi hutan-hutan alam. 
10.1 Sasaran pengelolaan hutan tanaman, termasuk sasaran konservasi pemulihan hutan alam, harus disebutkan dalam rencana pengelolaan secara tegas, dan ditujukan dalam pelaksanaan rencana secara jelas.

10.2 Bentuk dan tata letak hutan tanaman harus mendukung perlindungan, pemulihan dan konservasi hutan alam, dan tidak meningkatkan tekanan terhadap hutan alam. Koridor satwa liar, kawasan aliran sungai dan mosaik tegakan hutan yang terdiri dari berbagai kelas umur dan periode rotasi, perlu digunakan dalam hutan tanaman, sesuai dengan skala operasi. Skala dan tata letak petak-petak hutan tanaman harus sesuai dengan pola-pola tegakan hutan yang terdapat dalam lansekap alami.

10.3 Keanekaragaman komposisi hutan tanaman lebih dianjurkan, untuk meningkatkan stabilitas ekonomi, ekologi dan sosial. Keanekaragaman seperti ini mungkin termasuk ukuran dan distribusi UPH menurut unit ruang pengelolaan dalam suatu lansekap, jumlah dan komposisi genetis suatu jenis, kelas umur dan strukturnya.

10.4 Pemilihan jenis untuk penanaman harus berdasarkan kesesuaian lokasi secara keseluruhan dan kesesuaian dengan sasaran pengelolaan. Untuk meningkatkan konservasi keanekaragaman hayati, jenis-jenis asli lebih dianjurkan daripada jenis eksotis dalam pendirian hutan tanaman dan pemulihan ekosistem yang telah merosot. Jenis eksotis, yang hanya digunakan jika kinerjanya lebih besar dibandingkan dengan jenis asli, harus dipantau secara hati-hati untuk mengetahui tingkat kematian yang luar biasa, penyakit, atau berjangkitnya serangga dan berbagai dampak ekologis yang merugikan.

10.5 Sebagian dari kawasan pengelolaan hutan, sesuai dengan skala hutan tanaman dan akan ditentukan berdasarkan standar-standar regional, perlu dikelola untuk memulihkan lokasinya sebagai hutan alam. 
10.6 Berbagai tindakan untuk memelihara atau meningkatkan struktur kesuburan tanah, dan kegiatan biologi perlu dilakukan. Teknik-teknik dan laju penebangan, konstruksi dan pemeliharaan jalan dan jalan setapak, dan pemilihan jenis tidak menyebabkan kemerosotan kualitas tanah dalam jangka panjang atau berbagai dampak yang merugikan terhadap kualitas air, jumlah atau penyimpangan substansial pada pola aliran drainase.

10.7 Berbagai tindakan untuk mencegah dan meminimumkan penyebaran hama, penyakit, kebakaran dan invasif tumbuhan baru perlu dilakukan. Pengelolaan hama terpadu harus merupakan bagian penting dari rencana pengelolaan, dengan mengandalkan metode-metode pencegahan dan pengendalian biologis dibandingkan penggunaan pestisida pupuk kimiawi. Pengelolaan hutan tanaman harus mengusahakan sedemikian rupa untuk tidak menggunakan pestisida dan pupuk kimia, termasuk penggunaannya di kebun bibit. Penggunaan bahan-bahan kimia juga dibahas dalam Kriteria 6.6 dan 6.7.

10.8 Sesuai skala dan keanekaragaman operasinya, pamantauan hutan tanaman perlu meliputi penilaian potensi dampak ekologis dan sosial di dalam dan di luar lokasi secara berkala (misalnya, regenerasi alami, dampak terhadap sumber daya air dan kesuburan tanah, dan berbagai dampak kesejahteraan lokal dan kesejahteraan sosial), selain elemenelemen yang dicantumkan dalam prinsip 8,6 dan 4. Tidak ada jenis pohon yang ditanam pada skala besar tanpa percobaan lokal sebelumnya dan/atau jika pengalaman telah menunjukkan bahwa jenis-jenis tersebut dapat beradaptasi secara ekologi dengan lokasi yang bersangkutan, tidak bersifat invasif, dan tidak mempunyai dampak ekologis negatif yang berarti terhadap ekosistem lain. Isu-isu sosial yang berkaitan dengan perolehan lahan untuk hutan-hutan tanaman, khususnya perlindungan 
kepemilikan hak-hak lokal, hak guna atau aksesnya perlu mendapat perhatian khusus.

\subsection{SET K\&I UNTUK KERANGKA KERJA REGIONAL}

\subsubsection{MONTREAL PROCESS}

Montreal process secara ringkas adalah sebagai berikut: ${ }^{38}$

Kelompok kerja Montreal Process didirikan dengan tujuan khusus untuk pengembangan dan penerapan K\&I yang disepakati secara internasional untuk mendukung pengelolaan hutan secara lestari. Kelompok kerja ini telah mengembangkan set 7 kriteria dan 67 indikator untuk konservasi dan pengelolaan hutan lestari di kawasan iklim sedang dan boreal.

Sejarah Montreal Process dimulai ketika Kanada mengadakan konvensi dalam suatu Seminar Internasional tentang Pakar Pembangunan Hutan Boreal dan Kawasan Iklim Sedang yang Berkelanjutan, setelah UN Conference on Environment and Development (UNCED), diselenggarakan di Rio de Janiero pada bulan Juni 1992. Seminar ini diadakan di Montreal, Kanada, pada bulan September 1993 khusus difokuskan pada pengembangan kriteria, dan indikator untuk pengelolaan hutan kawasan iklim sedang dan boreal secara lestari dan menyediakan landasan konseptual bagi penyiapan kriteria, dan indikator regional dan internasional selanjutnya $(\mathrm{K} \& \mathrm{I})$.

38 Tiga paragraf berikut ini disadur dari web page dari Australian Department of Primary Industries and Energy http://www.dpie.gov.agfor/forests/montreal/international.html. K\&I Montreal process dapat diperoleh di http://www.dpie.gov.agfor/forests/montreal/c-i.html. 
Inisiatif ini menghasilkan pembentukan kelompok kerja kriteria, dan indikator untuk Konservasi dan Pengelolaan Hutan di Kawasan Iklim Sedang dan Boreal secara lestari, pada bulan Juni 1994, yang sekarang dikenal dengan Kelompok Kerja 'Montreal Process'.

\section{KRITERIA 1: KONSERVASI KEANEKARAGAMAN HAYATI}

Keanekaragaman hayati meliputi berbagai elemen keragaman ekosistem, keragaman di antara jenis, dan keragaman genetis dalam satu jenis.

\section{Indikator:}

\section{Keanekaragaman Ekosistem}

a. Luas kawasan menurut tipe hutan relatif luas total hutan - (a)..$^{39}$

b. Luas kawasan menurut tipe hutan dan kelas umur atau tahap suksesi (b);

c. Luas kawasan menurut tipe hutan dalam kategori-kategori kawasan lindung seperti yang ditentukan oleh $\mathrm{IUCN}^{40}$ atau sistem klasifikasi lainnya - (a);

d. Luas kawasan menurut tipe hutan dalam kawasan lindung ditentukan oleh kelas umum atau tahap suksesi - (b); dan

e. Fragmentasi tipe-tipe hutan-(b).

39 Indikator-indikator diikuti oleh huruf 'a' di mana kebanyakan data tersedia. Indikator yang diikuti oleh huruf 'b' di mana mungkin memerlukan kumpulan data baru atau tambahan dan/atau program baru pengambilan sampel secara sistematis atau penilaian dasar.

${ }^{40}$ Kategori-kategori IUCN meliputi: I. Perlindungan ketat; II. Konservasi ekosistem dan pariwisata; III. Konservasi ciri-ciri alami; IV. Konservasi melalui pengelolaan aktif; V. Konservasi dan rekreasi lansekap/laut; VI. Penggunaan ekosistem alam secara lestari. 


\section{Keanekaragaman Jenis}

a. Jumlah jenis yang bergantung pada hutan - (b); dan

b. Status (bahaya, langka, rentan, terancam punah) jenis yang bergantung pada hutan yang berisiko tidak dapat memelihara kelangsungan populasi yang berkembangbiak, seperti ditentukan oleh undang-undang atau penilaian ilmiah - (a).

\section{Keanekaragaman Genetis}

a. Jumlah jenis yang bergantung pada hutan yang sekarang hanya menempati sebagian kecil dari wilayah sebarannya - (b); dan

b. Tingkat populasi jenis yang mewakili berbagai habitat berbeda yang dipantau dari seluruh wilayah sebarannya - (b).

\section{KRITERIA 2: PEMELIHARAAN KAPASITAS PRODUKTIF EKOSISTEM HUTAN}

Indikator:

a. Luas lahan hutan dan luas lahan bersih yang tersedia untuk produksi kayu - (a);

b. Jumlah tegakan total yang terdiri dari jenis yang dapat diperdagangkan dan yang tidak pada lahan hutan yang tersedia untuk produksi kayu (a);

c. Luas dan tegakan hutan yang masih tumbuh di hutan tanaman yaitu jenis asli dan eksotis - (a);

d. Penebangan hasil-hasil kayu tahunan dibandingkan dengan volume yang dianggap pada tingkat lestari - (a); dan

e. Pemanenan HHNK tahunan (misalnya, kulit binatang, arbei, jamur, binatang buruan), dibandingkan dengan tingkat yang dianggap lestari- (b). 


\section{KRITERIA 3: PEMELIHARAAN KESEHATAN DAN VITALITAS EKOSISTEMHUTAN}

Indikator:

a. Luas dan persentase hutan yang dipengaruhi oleh proses-proses atau sebab-sebab di luar variasi sejarah, misalnya, oleh serangga, penyakit, persaingan dengan jenis eksotis, kebakaran, badai, pembukaan lahan, pengenangan permanen, salinisasi, dan binatang peliharaan- (b);

b. Luas dan persentase lahan hutan yang dipengaruhi oleh pencemaran udara tertentu (misalnya, sulfat, nitrat, ozon) atau ultraviolet B yang dapat menimbulkan berbagai dampak negatif terhadap ekosistem hutan- (b); dan

c. Luas dan persentase lahan hutan dengan komponen biologis yang semakin menurun, yang menunjukkan perubahan proses ekologis yang mendasar (misalnya, siklus hara tanah, penyebaran biji, peyerbukan) dan atau kontinutas ekologi (pemantauan jenis-jenis penting dalam fungsi hutan seperti jamur, epifit arboreal, nematoda, kumbang, lebah, dll) - (b).

KRITERIA 4: KONSERVASI DAN PEMELIHARAAN TANAH DAN SUMBER DAYA AIR

Kriteria ini meliputi konservasi tanah dan sumber daya air dan fungsi-fungsi protektif dan produktif hutan.

Indikator:

a. Luas dan persentase lahan hutan yang mengalami erosi tanah yang berarti - (b);

b. Luas dan persentase lahan hutan terutama yang dikelola untuk kepentingan perlindungan fungsi-fungsi, misalnya, perlindungan DAS, perlindungan dari banjir, perlindungan dari longsor, kawasan tepi sungai - (a); 
c. Persentase aliran panjang sungai di daerah resapan air berhutan yang aliran air dan waktunya jelas menyimpang dari sejarah kisaran variasinya - (b);

d. Luas dan persentase lahan hutan yang tanah-tanahnya telah banyak kehilangan zat-zat organik dan/atau tanahnya telah berubah mengandung zat-zat kimia lain - (b);

e. Luas dan persentase lahan hutan yang menjadi tanah padat atau sifatsifat fisiknya berubah akibat kegiatan-kegiatan manusia - (b);

f. Persentase badan air di kawasan hutan (misalnya, panjang aliran, luas danau) dengan variasi yang berarti dibandingkan sejarah kisaran variasi keanekaragaman hayati - (b);

g. Persentase badan air di kawasan hutan (misalnya, panjang aliran, luas danau) dengan variasi yang berarti dibandingkan kisaran variasi $\mathrm{pH}$, oksigen terlarut, tingkat zat-zat kimia (konduktivitas listrik), pengendapan atau perubahan suhu - (b); dan

h. Luas dan persentase lahan hutan yang mengalami penimbunan zat-zat beracun yang persisten - (b).

\section{KRITERIA 5: PEMELIHARAAN KONTRIBUSI HUTAN TERHADAP SIKLUS KARBON DITINGKAT GLOBAL}

Indikator:

a. Biomassa total ekosistem hutan dan penampungan karbon, dan bila mungkin, menurut tipe hutan, kelas umur, dan tahap suksesi - (b);

b. Kontribusi ekosistem hutan terhadap neraca karbon global termasuk penyerapan dan pelepasan karbon (biomassa yang masih tegak, puingpuing kayu kasar, karbon tanah dan rawa) - (a atau b); dan

c. Kontribusi hasil-hasil hutan terhadap neraca karbon global- (b). 
KRITERIA 6: PEMELIHARAAN DAN PENINGKATAN BERBAGAI MANFAAT SOSIAL EKONOMI JANGKA PANJANG UNTUK MEMENUHI KEBUTUHAN MASYARAKAT

Indikator:

\section{Produksi dan Konsumsi}

a. Nilai dan volume produksi kayu dan hasil-hasil kayu, termasuk nilai tambah melalui pengolahan di hilir - (a);

b. Nilai dan jumlah produksi HHNK - (b);

c. Pemasokan dan konsumsi kayu dan hasil-hasil kayu, termasuk konsumsi per kapita - (a);

d. Nilai kayu dan produksi HHNK sebagai persentase PDB - (a atau b);

e. Tingkat daur ulang hasil-hasil hutan - (a atau b); dan

f. Pemasokan dan konsumsi HHNK - (a atau b).

\section{Rekreasi dan Pariwisata}

a. Luas dan persentase lahan hutan yang dikelola untuk rekreasi dan pariwisata umum, berkaitan dengan luas total lahan hutan - (a atau b);

b. Jumlah dan tipe fasilitas yang tersedia untuk rekreasi dan pariwisata umum, berkaitan dengan jumlah penduduk dan luas kawasan hutan- (a atau b); dan

c. Jumlah hari kunjungan dihubungkan dengan rekreasi dan pariwisata, berkaitan dengan jumlah penduduk dan luas kawasan hutan - (b).

\section{Investasi di sektor kehutanan}

a. Nilai investasi, termasuk investasi untuk pertumbuhan hutan, kesehatan dan pengelolaan hutan, hutan tanaman, pengolahan kayu, rekreasi dan pariwisata - (a);

b. Tingkat pengeluaran untuk penelitian dan pengembangan dan pendidikan - (b); 
c. Penyuluhan dan penggunaan teknologi baru dan perkembangan teknologi - (b); dan

d. Kecepatan pengembalian investasi- (b).

\section{Kepentingan dan nilai-nilai budaya, sosial dan spiritual}

a. Luas dan persentase lahan hutan yang dikelola berkaitan dengan luas total lahan hutan untuk melindungi berbagai kepentingan dan nilai-nilai budaya, sosial dan spiritual - (a atau b); dan

b. Nilai-nilai hutan untuk nonkonsumsi- (b).

\section{Lapangan kerja dan kebutuhan masyarakat}

a. Lapangan kerja langsung dan tidak langsung dalam sektor kehutanan dan lapangan kerja sektor kehutanan sebagai sebuah bagian dari lapangan kerja total - (a atau b);

b. Tingkat nilai upah rata-rata dan kecelakaan dalam kategori-kategori lapangan kerja utama di sektor kehutanan - (a);

c. Kelangsungan hidup kemampuan masyarakat yang mengandalkan hutan, termasuk masyarakat indijenus untuk adaptasi dengan perubahan kondisi-kondisi ekonomi - (b); dan

d. Luas dan persentase lahan hutan yang digunakan untuk kepentingan subsisten - (b).

KRITERIA 7: KERANGKA KERJA LEGAL DAN EKONOMI UNTUK KONSERVASI HUTAN DAN PENGELOLAAN SECARA LESTARI

Catatan: Kriteria 7 dan indikator-indikator yang berkaitan dengan seluruh kerangka kerja kebijakan suatu negara yang memudahkan konservasi dan pengelolaan hutan secara lestari. Termasuk didalamnya adalah kondisikondisi masyarakat dan proses-proses eksternal yang sering di luar hutan itu 
sendiri tetapi mungkin mendukung usaha konservasi, memelihara atau meningkatkan satu atau lebih dari kondisi-kondisi, ciri-ciri, fungsi-fungsi dan berbagai manfaat yang tercakup dalam Kriteria 1 - 6. Urutan daftar indikator tidak berarti urutan prioritas masing-masing indikator.

Indikator:

Sejauh mana kerangka kerja legal (undang-undang, peraturan, panduan) mendukung konservasi dan pengelolaan hutan secara lestari:

a. Kejelasan hak-hak milik, menyediakan aturan kepemilikan lahan yang tepat, melalui hak-hak adat dan tradisonal masyarakat indijenus, dan menyediakan cara-cara untuk menyelesaikan konflik kepemilikan melalui proses secara adil;

b. Menyediakan perencanaan berkala yang berkaitan dengan hutan, pengkajian penilaian dan kebijakan yang mengakui berbagai nilai hutan, termasuk koordinasi dengan sektor-sektor yang terkait;

c. Menyediakan kesempatan bagi masyarakat untuk berperanserta dalam perumusan kebijakan dan pengambilan keputusan yang berkaitan dengan hutan dan akses masyarakat terhadap informasi;

d. Mendorong cara-cara pengelolaan hutan yang terbaik; dan

e. Mendorong pengelolaan hutan untuk mengkonservasi lingkungan yang memiliki nilai budaya, sosial dan/atau ilmiah yang khas.

Sejauh mana kerangka kerja kelembagaan mendukung konservasi dan pengelolaan hutan lestari termasuk kapasitas untuk:

a. Menyediakan kegiatan-kegiatan yang melibatkan masyarakat dan program-program pendidikan masyarakat, penyadartahuan dan penyuluhan, dan menyediakan informasi yang berkaitan dengan hutan;

b. Menangani dan melakukan perencanaan berkala yang berkaitan dengan 
hutan, penilaian, dan mengkaji ulang kebijakan termasuk perencanaan lintas sektoral dan koordinasi;

c. Meningkatkan dan memelihara ketrampilan sumber daya manusia dalam berbagai disiplin ilmu yang relevan;

d. Meningkatkan dan memelihara infrastruktur fisik yang efisien untuk memudahkan pemasokan hasil-hasil dan berbagai jasa hutan dan mendukung pengelolaan hutan; dan

e. Menegakkan berbagai undang-undang, peraturan dan panduan.

\section{Sejauh mana kerangka kerja ekonomi (kebijakan dan berbagai tindakan} ekonomi) mendukung konservasi dan pengelolaan hutan lestari melalui:

a. Kebijakan investasi dan pajak dan lingkungan peraturan yang mengakui investasi yang bersifat jangka panjang dan memungkinkan aliran modal masuk dan keluar dari sektor kehutanan untuk menanggapi permintaanpermintaan pasar, penilaian ekonomi nonpasar, dan keputusankeputusan kebijakan masyarakat untuk memenuhi permintaan jangka panjang terhadap hasil-hasil berbagai jasa hutan; dan

b. Tidak ada kebijakan perdagangan diskriminatif untuk hasil-hasil hutan.

Kapasitas untuk mengukur dan memantau perubahan konservasi dan pengelolaan hutan secara lestari, meliputi

a. Ketersediaan dan pembaruan data, statistik dan informasi penting lainnya untuk mengukur atau menjelaskan indikator-indikator yang berkaitan dengan Kriteria 1 - 7;

b. Cakupan, frekuensi dan keterpercayaan secara statistik untuk inventarisasi hutan, penilaian, pemantauan dan informasi lain yang relevan; dan

c. Kesesuaian dengan pengukuran, pemantauan dan pelaporan indikatorindikator yang dilakukan oleh negara-negara lain. 
Kapasitas untuk melakukan dan menerapkan penelitian dan pengembangan yang bertujuan untuk meningkatkan pengelolaan hutan dan penyaluran hasil-hasil dan berbagai jasa hutan, termasuk:

a. Pengembangan pemahaman ciri-ciri dan fungsi-fungsi ekosistem hutan secara ilmiah;

b. Pengembangan metodologi untuk mengukur dan menggabungkan biaya dan manfaat lingkungan dan sosial ke dalam kebijakan pasar dan publik, dan untuk mencerminkan penipisan sumber daya yang berkaitan dengan hutan dalam suatu sistem neraca nasional;

c. Berbagai teknologi dan kapasitas baru untuk menilai akibat-akibat sosial ekonomi yang berkaitan dengan pengenalan berbagai teknologi baru;

d. Meningkatkan kemampuan untuk meramal dampak intervensi manusia terhadap hutan; dan

e. Kemampuan untuk memprediksi kemungkinan dampak perubahan iklim terhadap hutan.

\subsubsection{TARAPOTO (KRITERIA UNTUK TINGKAT UNIT PENGELOLAAN) ${ }^{41}$}

Pada tahun 1995, Bolivia, Brasil, Kolombia, Peru, Suriname dan Venezuela (negara-negara Amazon Cooperation Treaty) setuju dengan tujuh kriteria dan 51 indikator di tingkat nasional, empat kriteria dan 23 indikator di tingkat unit pengelolaan dan satu kriteria dan tujuh indikator untuk tingkat umum. Hanya kriteria dan indikator untuk tingkat unit pengelolaan yang disajikan di bawah ini.

${ }^{41}$ Set Tarapoto mencakup K\&I pada tingkat yang lebih tinggi daripada tingkat unit pengelolaan, tetapi $K \& I$ tersebut tidak dimasukkan di sini. 


\section{KRITERIA 8: KERANGKA KERJA LEGAL DAN KELEMBAGAAN}

Indikator:

a. Rencana pengelolaan hutan diakui oleh pihak-pihak berwenang yang kompeten;

b. Evaluasi periodik terhadap pelaksanaan rencana pengelolaan dan persentase rata-rata pelaksanaannya; dan

c. Kerangka kerja legal yang menjamin stabilitas investasi jangka panjang di sektor kehutanan.

\section{KRITERIA 9: PRODUKSI KEHUTANAN SECARA LESTARI}

Indikator:

a. Penebangan kayu tahunan dan HHNK sesuai dengan kapasitas sumber daya dasar untuk menghasilkannya pada tingkat yang lestari;

b. Luas dan persentase lahan hutan yang dipengaruhi oleh perubahan sifatsifat fisik atau kimia dan erosi secara berarti;

c. Keefektifan sistem administrasi dan pengendaliannya;

d. Tingkat diversifikasi produksi; dan

e. Tingkat pemanfaatan teknologi yang ramah lingkungan.

\section{KRITERIA 10: KONSERVASI EKOSISTEM HUTAN}

Indikator:

a. Bagian kawasan produksi tetap dalam kawasan yang dilindungi;

b. Berbagai tindakan untuk melindungi, memulihkan kembali dan penggunaan populasi jenis liar yang terancam punah secara lestari;

c. Luas dan persentase hutan yang dipengaruhi oleh proses-proses atau sebab-sebab alami lainnya (serangan serangga, penyakit, kebakaran, dll) dan oleh kegiatan-kegitan manusia; 
d. Laju regenerasi dan struktur ekosistem hutan;

e. Berbagai tindakan konservasi tanah; dan

f. Berbagai tindakan untuk melindungi aliran air dari kegiatan kehutanan.

\section{KRITERIA 11: MANFAAT SOSIAL EKONOMI HUTAN}

Indikator:

a. Kualitas hidup penduduk lokal;

b. Kemampuan mendapat keuntungan dan kecepatan pengembalian modal dalam pengelolaan hutan;

c. Efisiensi sistem produksi dan transformasi hasil-hasil hutan;

d. Pengaruh penggunaan hutan untuk kepentingan ekonomi terhadap ketersediaan sumber daya hutan yang penting bagi penduduk lokal. Jumlah lapangan kerja langsung dan tidak langsung, dan tingkat pendapatan.

e. Sifat dan jumlah manfaat yang diperoleh dari pengelolaan hutan;

f. Jumlah hasil-hasil hutan yang dipanen per hektar per tahun;

g. Nilai total produksi; dan

h. Berbagai mekanisme konsultasi dan peranserta masyarakat yang efektif dalam mengelola sumber daya hutan, bergantung pada skala pengelolaan. 


\section{Sistem CGIAR}

The Consultative Group on International Agricultural Research (CGIAR) adalah suatu asosiasi informal yang terdiri dari 41 organisasi donor dari sektor publik dan swasta yang mendukung jaringan enam belas lembaga penelitian internasional di bidang pertanian, di mana CIFOR merupakan anggota terbaru. Asosiasi ini didirikan pada tahun 1971. Pusat-pusat CGIAR merupakan bagian sistem penelitian global di bidang pertanian yang berusaha menerapkan kemampuan ilmiah internasional untuk menyelesaikan masalah-masalah yang dihadapi oleh masyarakat miskin di dunia.

\section{CIFOR}

CIFOR adalah bagian sistem CGIAR dengan tugas khusus untuk menanggapi kepedulian global tentang dampak kerusakan dan kehilangan hutan terhadap kondisi sosial, lingkungan dan ekonomi masyarakat. CIFOR beroperasi melalui berbagai kemitraan yang sangat terdesentralisasi dengan lembaga-lembaga dan/atau individu terpenting di seluruh negara industri dan negara yang sedang berkembang. Sifat dan jangka waktu kemitraan ini ditentukan oleh masalahmasalah penelitian khusus yang dihadapi. Agenda penelitian ini terus-menerus dikaji dan selalu mengalami perubahan ketika para mitra menemukan berbagai masalah dan peluang baru. 
Panduan ini berisi metode-metode untuk membantu pengembangan dan evaluasi kriteria dan indikator (K\&l) yang selanjutnya dapat digunakan untuk menilai kelestarian pengelolaan hutan. Panduan ini ditujukan terutama bagi para peneliti, masyarakat atau kelompok yang tertarik dalam mengevaluasi K\&l untuk menilai hutan di kawasan baru, atau sebagai referensi untuk para pembaca yang ingin mengetahui bagaimana Acuan Generik CIFOR dihasilkan. Berbagai metode yang disajikan dimaksudkan untuk pengembangan set K\&I untuk hutan alam pada tingkat unit pengelolaan hutan (UPH), terutama di kawasan tropis. Setelah bagian pendahuluan yang menjelaskan tujuan, sasaran utama, dan proses pengembangan K\&l secara keseluruhan, tiga bab berikutnya (2-4) membahas cara menyiapkan K\&l untuk pengujian, bagaimana melakukan pengujian, dan bagaimana menganalisis hasilnya. Bab 5-7 menjelaskan konsep dasar pengembangan $\mathrm{K} \& \mathrm{I}$, dan di dalamnya diberikan tiga contoh kasus, serta bahan bacaan tambahan yang diusulkan. Formulir khusus dan perangkat yang telah digunakan dalam pengujian CIFOR juga disajikan (Bab 8), dengan contoh cara memperoleh hasilnya. Bab 9 menyajikan berbagai kemungkinan set dasar kriteria dan indikator, untuk membantu para pengguna mengevaluasi dan menguji dalam konteks mereka sendiri. 